\title{
A mézelő méh sejt-közvetítette immunitása
}

\author{
Ph.D. értekezés
}

Készítette: Gábor Erika

Témavezetők: Prof. Dr. Andó István és Dr. Kurucz Judit Éva

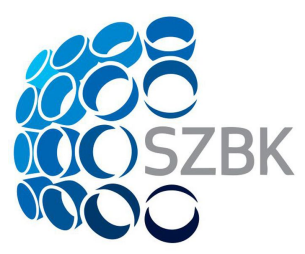

MTA Szegedi Biológiai Kutatóközpont

Genetikai Intézet, Immunológiai Témacsoport

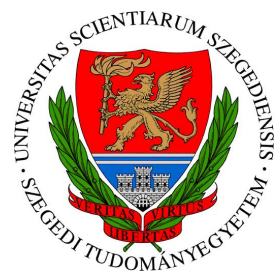

Biológia Doktori Iskola

Szegedi Tudományegyetem

Természettudományi és Informatikai Kar

2018.

Szeged 


\section{Tartalomjegyzék}

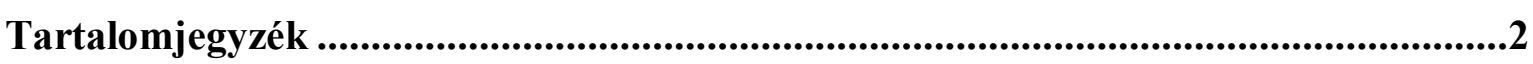

Rövidítések jegyzéke .........................................................................................................................5

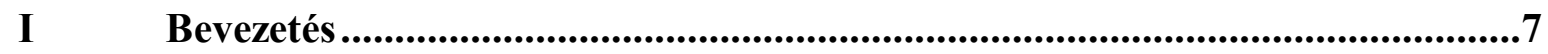

I.1 A mézelő méh jellemzése .................................................................

I.2 A mézelö méh kórokozói (........................................................... 8

I.3 Alternatív stratégiák a kórokozók ellen ................................................. 11

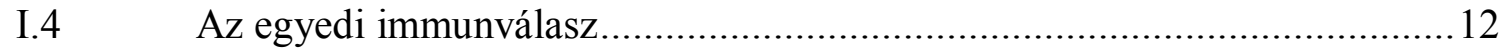

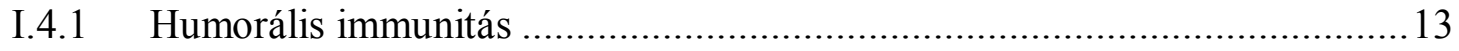

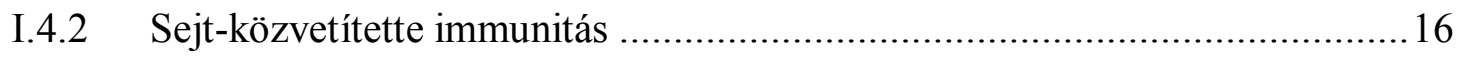

I.4.3 A rovarok sejt-közvetítette immunválaszának vizsgálata............................ 18

I.4.4 A mézelő méh vérsejttípusai ................................................................ 19

I.4.5 A mézelő méh sejt-közvetítette immunválasza a kasztok egyedfejlődése és a fertőzések során.............................................................................20

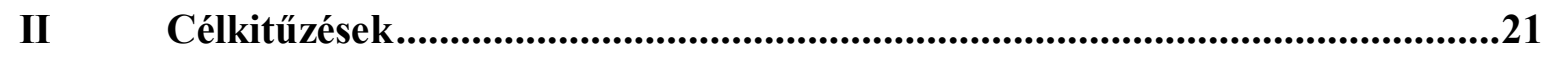

III Anyagok és módszerek .....................................................................................22

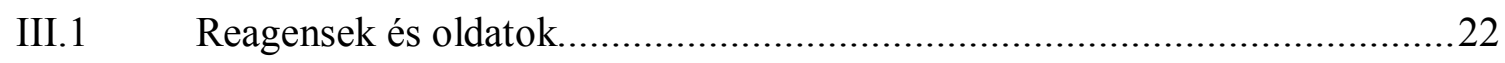

III.2 A kísérleti egyedek tartási körülményei ..................................................24

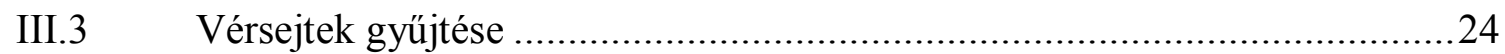

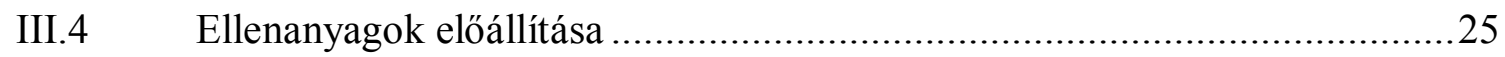

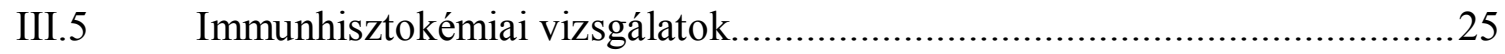

III.6 Indirekt immunfluoreszcens vizsgálatok ..............................................26

III.7 Permeabilizált, fixált vérsejtek áramlási citometriás vizsgálata .................27

III.8 Baktériumok FITC jelölése .............................................................. 27

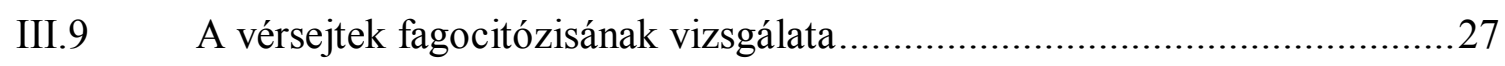

III.10 A hemolimfa alvadék vizsgálata .................................................... 28

III.11 Az idegen test elhatárolásának vizsgálata a testüregtől............................28 


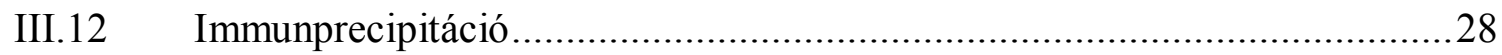

III.13 Minta-előkészítés egész állatokból...................................................28

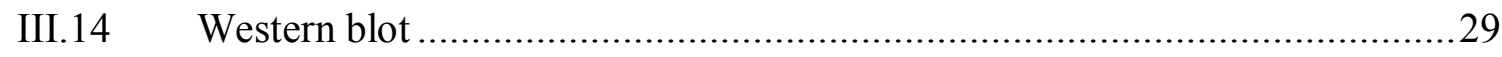

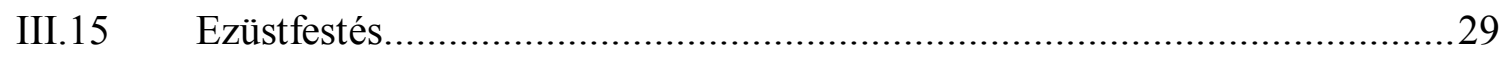

III.16 Duplaszálú RNS készítése (dsRNS) és RNS interferencia.........................29

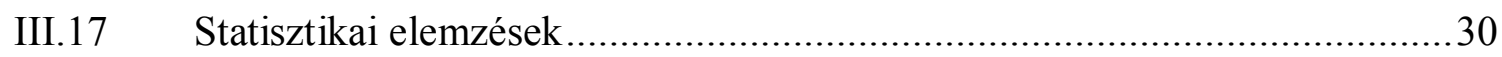

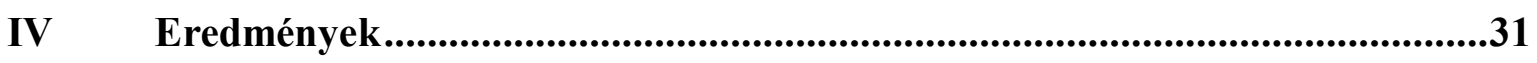

IV.1 A vérsejteken kifejeződő immunológiai markerek csoportosítása..................31

IV.2 Kifejlett dolgozó középbél- és lárvális kutikula szövetek vizsgálata..............34

IV.3 A különböző kasztok vérsejttípusainak összehasonlítása molekuláris

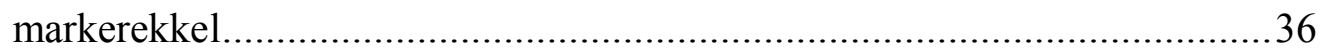

IV.4 A mézelő méhben azonosított markerek kifejeződésének vizsgálata Drosophila melanogaster és Bombyx mori vérsejteken ....

IV.5 A mézelő méh vérsejtek citoplazmájában kifejeződő markerek áramlási

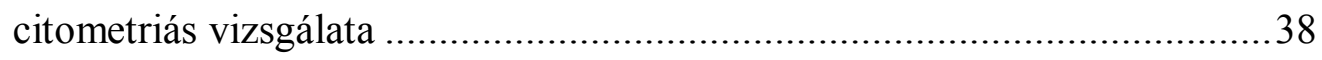

IV.6 A mézelő méh vérsejt alpopulációinak funkcionális vizsgálata ..................40

IV.6.1 A mézelő méh vérsejtek fagocitáló képességének vizsgálata.......................40

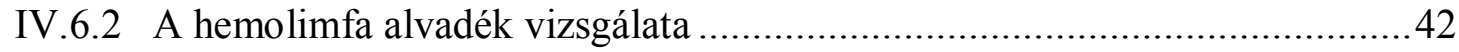

IV.6.3 A testidegen részecske elhatárolásának vizsgálata.....................................43

IV.6.4 Vajk fehérjék vizsgálata mézelő méhben ...............................................44

IV.7 A plazmatocita, önocita és granulocita-önocita markerek molekulatömegének meghatározása ....................................................4 46

IV.8 A mézelő méh vérsejtjein azonosított markermolekulák jellemzésének

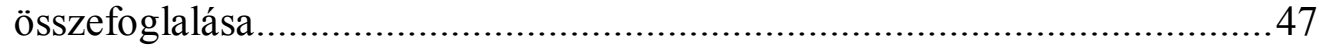

IV.9 A 2.28 önocita marker további jellemzése..................................................48

IV.10 A mézelő méh hemolektin azonosítása $(\mathrm{AmHml})$......................................49

IV.11 A plazmatocita vérsejt populáció vizsgálata vegyszereknek kitett és vegyszerrel kezelt méhcsaládok egyedeiben ........................................50 
IV.11.1 Neonikotinoiddal csávázott vetőmagból fejlődő méhlegelő .51

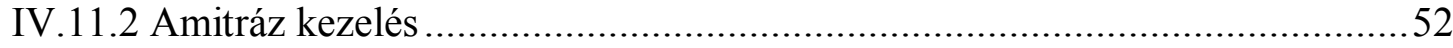

IV.12 Varroa szenzitív higiénikus képességü (VSH) méhcsaládok vizsgálata ........53

IV.13 Atkafertőzött méhcsalád egyedeinek vizsgálata …...................................53

V Az eredmények megbeszélése..............................................................................55

VI Az eredmények összefoglalása ........................................................................62

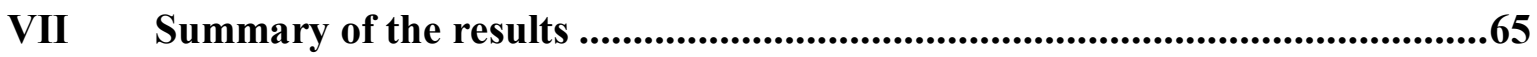

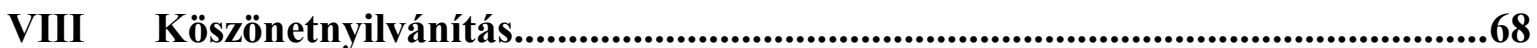

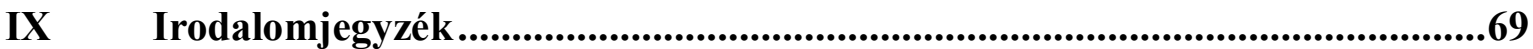

X Saját közlemények jegyzéke......................................................................83 


\section{Rövidítések jegyzéke}

$\begin{array}{ll}\text { AEC } & \text { 3-amino-9-etilkarbazol } \\ \text { ABPV } & \text { heveny méhbénulás vírus } \\ \text { AMP } & \text { antimikrobiális peptid } \\ \text { AmHml } & \text { A.mellifera hemolektin } \\ \text { BSA } & \text { borjú szérumalbumin } \\ \text { CCD } & \text { Colony Collapse Disorder } \\ \text { DAP } & \text { diaminopimelinsav } \\ \text { DAPI } & \text { 4,6-diaminido-2-fenillindol } \\ \text { DMP } & \text { dimetil-pimelimidát-dihidroklorid } \\ \text { DMSO } & \text { dimetil-szulfoxid } \\ \text { dsRNS } & \text { duplaszálú ribonukleinsav } \\ \text { DWV } & \text { szárnytorzulást okozó vírus } \\ \text { EDTA } & \text { 2-[2-(Bisz(karboximetil)amino)etil-(carboximetil)amino]ecetsav } \\ \text { EGF } & \text { epidermális növekedési faktor } \\ \text { EM } & \text { elektronmikroszkóp } \\ \text { FACS } & \text { áramlási citometria } \\ \text { FBS } & \text { újszülött borjúszérum } \\ \text { FITC } & \text { fluoreszcein-izotiocianát } \\ \text { GFP } & \text { zöld fluoreszcens protein } \\ \text { HAT } & \text { hipoxantin-aminopterin-timidin } \\ \text { Hml } & \text { hemolektin } \\ \mathrm{H}_{2} \mathrm{O}_{2} & \text { hidrogén-peroxid } \\ \text { HRP } & \text { tormaperoxidáz } \\ \text { Ig } & \text { immunoglobulin } \\ \text { Imd } & \text { immundeficiencia } \\ \text { JAK } & \text { Jánusz-kináz } \\ \text { JNK } & \text { c-Jun N-terminális kináz } \\ \text { l(3)mbn } & \text { lethal (3) malignant blood neoplasm }\end{array}$


LC-MS/MS folyadékkromatográfiával kapcsolt tandem tömegspektrometria

$\mathrm{mAb} \quad$ monoklonális ellenanyag

NLS nukleáris lokalizációs szignál

PAMP patogén-asszociált molekuláris mintázat

PBS foszfátokkal pufferelt fiziológiás sóoldat

PEG polietilén-glikol

PGRP peptidoglikán felismerő fehérje

PPO profenoloxidáz

PTU 1-fenil-2-tiourea

PVDF poli-1,1 difluoretilén

RNS ribonukleinsav

SDS sodium dodecil sulphate

SPZ Spätzle

STAT Signal Transducer and Activator of Transcription

T2/48 humán leukocita elleni antigén

VSH Varroa szenzitív higiénikus képesség 


\title{
I Bevezetés
}

\section{I.1 A mézelő méh jellemzése}

\author{
Regnum: Animalia \\ Phylum: Arthropoda \\ Classis: Insecta
}

Ordo: Hymenoptera

Familia: Apiidae

Genus: Apis

Species: Apis mellifera

A mézelő méh több ezer évvel ezelőtt háziasított, kozmopolita elterjedésű, kizárólag családokban élő euszociális rovar. Egy család általában 20 000-80 000 egyedbő1 áll, amelyek 3 kasztot alkotnak: a méhanya, a dolgozók és a herék. Az anya (szaporodóképes nőstény) megtermékenyített petéket helyez a dolgozók (nem szaporodóképes nőstények) által viaszból épített hatszögletű lépsejtekbe. A fiatal dolgozók a kaptárban belső munkát végeznek: gondozzák az anyát, a fiatal egyedeket és a lépet, a potroh hasi oldalán található viaszmirigyek a sejtek építéséhez szükséges viaszt termelik. Az idősebb dolgozók külső munkássá válnak: virágport, nektárt és vizet gyüjtenek. A herék (hímek) a párzásban és a méz érlelésében vesznek részt.

Az egyedek teljes átalakulással fejlődnek (holometamorphosis). A pete 3 nap után lárvává (álca) alakul, 6-9 nap alatt 5 lárvastádiumon megy keresztül (L1-L5). Az utolsó lárvastádium végén, amikor az egyedek elérték a báb stádiumot a dolgozók befedik a sejtet, amelyböl a peterakást követő 16.-24. napon a kifejlett egyed kirágja magát. A pete, lárva és báb stádiumokat összefoglaló néven fiasításnak nevezzük. Az egyedfejlődés időtartama kasztonként eltérő (1. ábra). A megtermékenyített diploid petékből nőstények, a megtermékenyítetlen haploid petékből hímek fejlődnek. A dolgozó méheket a fiatal egyedek (dajka méhek) a fejlődés korai szakaszában garatmirigyük váladékával, a méhpempővel etetik, majd virágporral és mézzel táplálják. Azokból a diploid egyedekből, amelyeket a sejt befedéséig táplálnak méhpempővel, méhanya fejlődik. 


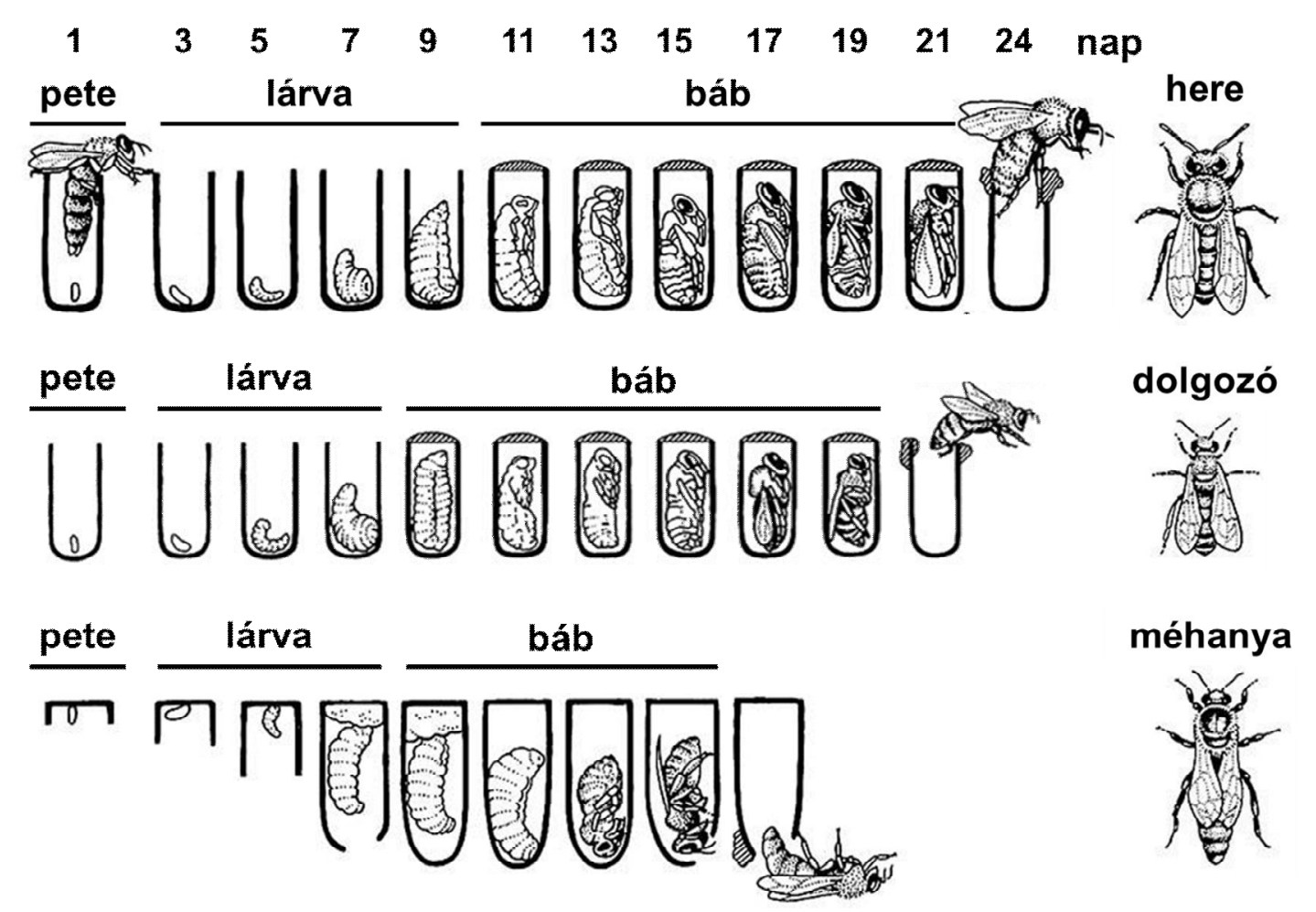

1. ábra A mézelő méh kasztok és fejlődési stádiumok összehasonlítása (Winston 1987 után, módosítva).

A dolgozók a nyári időszakban általában 20-40 napig élnek, azonban az ősszel kikelt egyedek az áttelelés során - amikor nincs fiasítás - akár 6 hónapig is életben maradhatnak. A herék körülbelül 30 napig élnek, azonban a párzás után elpusztulnak. A méhanya átlagosan 3 évig él, de élettartama akár a hat évet is elérheti (Winston, 1987).

A mézelő méh mind ökológiai, mind gazdasági szempontból az egyik legjelentősebb haszonállat. A növények beporzásával jelentős mértékben hozzájárul a bioszféra egyensúlyának a fenntartásához. Pótolhatatlan a méztermelésben és a különböző „méhtermékek”, az élelmiszeripar, a gyógyszeripar és a kozmetikai ipar alapanyagául szolgáló, propolisz, virágpor és méhméreg előállításában (Burlando és Cornara, 2013, Cherniack, 2010, Gallai és mtsai., 2009, Han és mtsai., 2013, Moritz és mtsai., 2010).

\section{I.2 A mézelő méh kórokozói}

Az utóbbi időben drámaian megemelkedett a kolóniák elnéptelenedésével járó, súlyos gazdasági károkat eredményező méhpusztulás, amely több faktor, patogének és egyéb környezeti tényezők együttes hatásának a következménye (Dainat és mtsai., 2012).

A lárvákat és a kifejlett egyedeket számos kórokozó károsítja. A lárvák és bábok, egyelőre gyógyíthatatlan fertőző rothadásához vezető amerikai nyúlós költésrothadást a Paenibacillus larvae subsp. larvae Gram-pozitív spóraképző, aerob baktérium okozza. A fertőzött lárvák elpusztulnak, maradványuk sürü, nyúlós anyaggá, majd beszáradva a 
lépsejt aljára ragadt fekete ún. pörkké alakul, amelyet a méhek nem tudnak eltávolítani a kaptárból. A P. larvae spórái ellenállóak, sokáig fertőzőképesek maradnak (Alippi és mtsai., 2002). Hasonló tünetei vannak a nem spóraképző Mellisococcus pluton által előidézett európai költésrothadásnak is, azonban ebben az esetben az elhalt álcák maradványa nem alakul át nyúlós anyaggá (Arai és mtsai., 2014). A Serratia marcescens sicaria (Ss1) Gram-negatív baktériumtörzset, a téli időszakban elpusztult kolóniákban azonosították. A fertőzött egyedek röpképtelenek kirekesztik őket a kolóniából (Burritt és mtsai., 2016). Májusban, a vízhiány okozta ún. májusi vész tüneteitől szenvedő méhcsaládoknál Spiroplasma fertőzést mutattak ki (Clark és mtsai., 1985).

A mézelő méhek gombafertőzéseknek is ki vannak téve, ezek egyike az Ascosphaera apis tömlösgomba okozta költésmeszesedés, amely évről évre világszerte egyre jobban terjed. A lépsejtek befedése után a fertőzött egyedek elpusztulnak, kiszáradnak és szürke múmiává alakulnak. Ezeket az egyedeket jó tisztogatási hajlammal rendelkező családok dolgozói felismerik és eltávolítják a lépsejtekből. Bár a fertőzés nem okoz kolóniamértékü pusztításokat, komoly gazdasági károkhoz vezethet (Aronstein és mtsai., 2010).

A mézelő méh vírusos megbetegedései közül a kifejlett egyedek szárnytorzulását a Deformed wing virus $(D W V)$ okozza. A fertőzött fiasításból röpképtelen dolgozók fejlődnek, amelyeket az egészséges dolgozók kirekesztenek a kolóniából (Chen és mtsai., 2007). A heveny méhbénulás vírussal (Acute Bee Paralysis Virus, ABPV) történő fertőzés során röpképtelen egyedek fejlődnek, a méhek a kaptár bejáratánál mászkálnak, így ez a betegség a méhcsalád népességének elvesztését okozza. Mivel a fertőzés a jó tisztogatási hajlamú méhek aktivitásának csökkenését eredményezi, ezért a betegség a kaptáron belül gyorsan elterjedhet (Sammataro és mtsai., 2000).

Napjainkban világszerte az egyik legveszélyesebb méh kórokozó a Varroa destructor atka. Külső parazitaként a bábok, és a kifejlett egyedek testnedveivel táplálkozik legyengítve azokat. A $V$. destructor csak néhány óráig képes táplálék nélkül életben maradni, ezért elterjedésében fontos szerepet játszik a méhek egymással történő érintkezése. A nagy méhsürüség, a vándorméhészetek, valamint a fertőzött méhek importja világszerte a parazita széleskörü elterjedéséhez vezetett (Beetsma, 1994, Matheson, 1996). Az atkák vírusfertőzéseket is terjesztenek, és a legyengült egyedek egyéb fertőzésekre is fogékonnyá válnak (Anderson és mtsai., 2000).

A Nosema apis és Nosema cerenae spórás egysejtüek a méhek kóros hasmenését idézik elő. A $N$. apis a kifejlett egyedek bélhámsejtjeit támadja meg, majd a spórák a 
bélcsatornába ürülnek, és a széklettel távoznak (Bailey és mtsai., 1983, Fries és mtsai., 1996). A N. apis elsősorban tavasszal okoz károkat (Fries, 1993), azonban az utóbbi években, több helyen, a nyár folyamán is izolálták a kórokozót a korábban csak Ázsiában azonosított $N$. cerenae-hoz hasonlóan (Higes és mtsai., 2006).

A közelmúltban az Egyesült Államokban felfedezték, hogy az Apocephalus borealis légy is szerepet játszhat a kaptárelhagyás jelenségében. Az A. borealis a kifejlett egyedek potrohában helyezi el petéjét, amelynek hatására a dolgozók elveszítik tájékozódási képességüket, a fény felé szállnak, és nem találnak vissza a kaptárba (Core és mtsai., 2012). Ezen kívül még két további fakultatív parazitát írtak le, amelyek petéi, hasonló módon, a kifejlett egyedekben fejlődnek. A Megaselia rufipes fajt Olaszország délkeleti részén írták le (Dutto és Ferrazzi, 2014), míg Algériában a Megaselia scalaris fajt azonosították a $D W V$ fertőzés lehetséges vektoraként (Menail és mtsai., 2016).

A paraziták és patogének mellett (2. ábra) a mezőgazdaságban használt növényvédő szerek, vetőmagok neonikotinoidokkal történő csávázása, továbbá a változó klimatikus viszonyok is nagymértékben hozzájárulhatnak a méhek pusztulásához (Farooqui, 2013, Simon-Delso és mtsai., 2014).

A mézelő méh a különböző patogének ellen egyedi immunválaszával, valamint szociális viselkedéséből adódó ún. alternatív stratégiák alkalmazásával veszi fel a harcot.

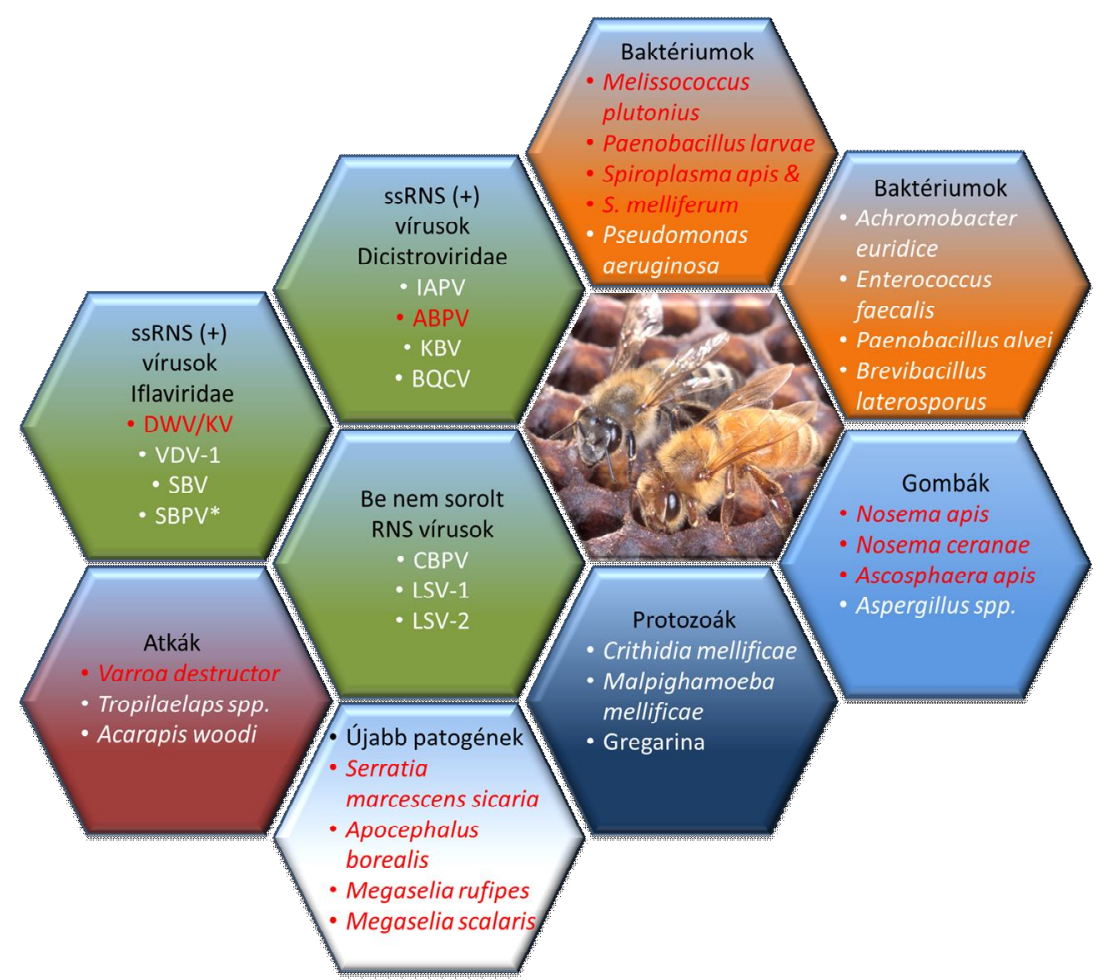

2. ábra A mézelő méh kórokozói. Pirossal jelölve a dolgozatban is ismertetett patogének (Evans és Schwarz, 2011 után módosítva). 


\section{I.3 Alternatív stratégiák a kórokozók ellen}

Egyéb szociális fajokhoz hasonlóan (Armitage és mtsai., 2010, Schlüns és Crozier, 2009) a mézelő méh egyedi immunrendszere kolóniaszintű védekezési folyamatokkal egészül ki. A méhcsaládra úgy tekinthetünk, mint egy ún. szuperorganizmusra. A család alkotja az egész egységet, egyedei önmagukban nem képesek életben maradni, hasonlóan a magasabb rendü szervezeteket felépítő sejtekhez. A magasabb rendü szervezetek különböző védekezési szintekkel rendelkeznek a kórokozók ellen, ami jellemző a szuperorganizmusként funkcionáló méhcsaládra is.

Az elsődleges védelmi vonal feladata a kórokozók kaptárba történő bejutásának a megakadályozása. Az idősebb dolgozók egy része nem a gyüjtögetésben vesz részt, hanem a kaptár kijáróját védi, olyan nagyobb méretü kártevőktől, mint a halálfejes lepkék vagy a darazsak. A méhek sokszor saját maguk juttatnak be a kaptárba környezetükből, vagy szomszédos méhcsaládokról testükre tapadt kórokozókat. A szomszédos kolóniákról átterjedt fertőzéseket horizontális fertőzésnek nevezzük, amelynek leggyakoribb esete az atkával történő fertőződés más méhészetekből. Ahhoz, hogy a gyüjtögető méhek csökkentsék a kórokozó bejutását a kaptár belsőbb részeibe, a gyüjtött élelmet a belső dolgozóknak adják át, így nem érintkeznek közvetlenül a kaptár központi részével, ahol a fejlődő egyedek és az anya tartózkodik.

A második védelmi szint a kaptárba bejutott fertőzés szétterjedésének megakadályozása, amelynek érdekében az egyedek rendszeresen tisztogatják egymást. A jó tisztogatási hajlammal rendelkező dolgozók az atkával fertőzött lárvákat és bábokat eltávolítják a kaptárból, ami megszakítja az atka szaporodási ciklusát. A magas tisztogatási hajlammal rendelkező méhvonalakat Varroa szenzitív higiénikus (VSH) képességü méheknek nevezzük. A tisztogatási hajlam méhvonalanként eltérő és öröklődik. E viselkedés meghatározását a lépsejtek felnyitásáért felelős „uncapped” és a fertőzött egyedek eltávolításáért felelős „removing” gének határozzák meg (Evans és Spivak, 2010, Rothenbuhler, 1964). A kaptárba bejutott nagyobb méretü kártevőket a méhek szociális enkapszulációval határolják el: testükkel körülvéve elzárják a táplálékforrástól és szárnymozgatásukkal lokálisan magas hőmérsékletet fejtenek ki. A költésmeszesedés kórokozója az A. apis ellen a család egyedei az egész kaptár hőmérsékletét is képesek megemelni, ami a méhek egyedfejlődését még nem befolyásolja, viszont a tömlősgomba szaporodását gátolja. Ezt a jelenséget kaptárláznak nevezzük. Amennyiben egy fertőzés 
olyan mértékü, hogy a család összeomlását okozhatja, a méhek kirajzanak, azaz elhagyják a kaptárt és új otthont építenek.

Az előbb ismertetett aktív védekezési stratégiák mellett a méhek passzív, azaz megelőző védekezési módszereket is alkalmaznak: a kaptár belsejét antimikrobiális hatású propolisszal vonják be, a lárvákat folyamatosan gondozzák és táplálják, a bábokat elzárják a külső környezettől a fejlődés legkritikusabb szakaszában, valamint az anyát speciális bölcsőben nevelik, méhpempővel táplálják és fokozottan védik, gondozzák. Az anyáról az utódgenerációra átadódó betegségeket nevezzük vertikális fertőzésnek (Alaux és mtsai., 2012, Cremer és mtsai., 2007, Cremer és Sixt, 2009, Evans és Spivak, 2010, Richard és mtsai., 2008, Wilson-Rich és mtsai., 2008).

\section{I.4 Az egyedi immunválasz}

A paraziták és mikroorganizmusok ellen a rovarok, beleértve a méheket is hatékonyan müködő immunrendszerrel rendelkeznek, amely a fertőzést követően, gyorsan aktiválódik és a válaszreakciók akár néhány órán belül lejátszódhatnak. Ez a védekezési forma két fő rendszerre bontható: humorális és sejt-közvetítette immunválaszra.

A humorális immunválasz esetén, az evolúció során konzervált receptor molekulák a kórokozókra általánosan jellemző molekuláris mintázatokat ismernek fel, majd olyan jelátviteli utakat aktiválnak, amelyek eredményeként antimikrobiális peptidek (AMP), a hemolimfa alvadási és melanizációs folyamataiban szerepet játszó molekulákat kódoló gének aktiválódnak (Cerenius és Söderhäll, 2011, Hoffmann és mtsai., 1999, Hultmark, 2003, Vilmos és Kurucz, 1998). Annak ellenére, hogy a szociális közeg kedvez a fertőzések gyors terjedésének a kolóniákban élő mézelő méhben kevesebb immunfunkcióért felelős gént azonosítottak az egyedül élő D. melanogaster és Anopheles gambiae fajok genomjához képest (Consortium, 2006, Evans és mtsai., 2006, Elsik és mtsai., 2014).

A sejt-közvetítette immunválasz végrehajtó sejtjei a vérsejtek, amelyek a mikroorganizmusokat bekebelezéssel (fagocitózissal), a nagyobb méretü kórokozókat pedig több sejtrétegből álló tokba zárva pusztítják el (Hoffmann és mtsai., 1999, Vilmos és Kurucz, 1998). A csoportunk által azonosított D. melanogaster Nimród génklaszter és Nim kromoszóma régióban található gének a mikroorganizmusok fagocitálásában szerepet játszó Nimrod fehérjéket kódolják. Kimutattuk, hogy a nimrod gének homológjai, valamint a vajk géneket is magában foglaló Nim kromoszóma régió homológjai a mézelő méhben is 
megtalálhatók (Cinege és mtsai., 2017, Kurucz és mtsai., 2007a, Somogyi és mtsai., 2010, Zsámboki és mtsai., 2013).

\section{I.4.1 Humorális immunitás}

A rovarok humorális immunválasza esetén, az evolúció során konzervált receptor molekulák, felismerik a kórokozókra általánosan jellemző molekuláris mintázatokat (PAMP), és különböző jelátviteli utakat aktiválnak (Toll, Imd, JAK/STAT), AMP-ek, valamint koagulációs és melanizációs folyamatokban résztvevő fehérjék termelődnek. A humorális immunválasz Drosophila fajokban már részletesen tanulmányozott (Cerenius és Söderhäll, 2011, Hoffmann és mtsai., 1999, Hultmark, 2003, Vilmos és Kurucz, 1998), a jelátviteli útvonalakban szerepet játszó fehérjéket kódoló gének homológjait a mézelő méhben is azonosították (3., 4. ábra) (Consortium, 2006, Evans és mtsai., 2006, Elsik és mtsai., 2014).

Az Imd jelátviteli útvonalat Drosophila-ban a diaminopimelinsav-típusú (DAP-típusú) peptidoglikánok aktiválják. A peptidoglycanrecognition protein-LC (PGRP-LC) transzmembrán receptor aktivációja során képződő szignalizációs komplex része a death domént tartalmazó Imd fehérje, a dFadd adaptor fehérje és a kaszpáz8 homológ Dredd, amely az Imd hasítását követő foszforilációs eseményeken keresztül aktiválja a Drosophila IKK komplexet, amely a Relish foszforilációját idézi elő. A Relish fehérje $\mathrm{C}$ terminális része a citoplazmában marad, míg az aktív N-terminális része a sejtmagba jutva antimikrobiális peptideket (Diptericin, CecropinA) kódoló géneket aktivál (Dushay és mtsai., 1996). A folyamatban a Tak1 és TAB2 molekulák az NF-kB és a JNK (c-Jun Nterminális kináz) jelátviteli útvonalak aktiválásában vesznek részt (3. ábra).

A JNK jelátviteli útvonal a sebgyógyulásban, stressz válaszban és apoptózisban szerepet játszó immungének átírásának szabályozásában vesz részt (Royet és Dziarski, 2007). Bakteriális illetve vírusfertőzést követően a JAK/STAT útvonal is aktiválódik, a hemociták által termelt Upd3 citokin-szerü molekula a JAK/STAT útvonal receptorához, a Domeless fehérjéhez kötődik és antivirális gének átírását szabályozza (Agaisse és mtsai., 2003) (3. ábra). 


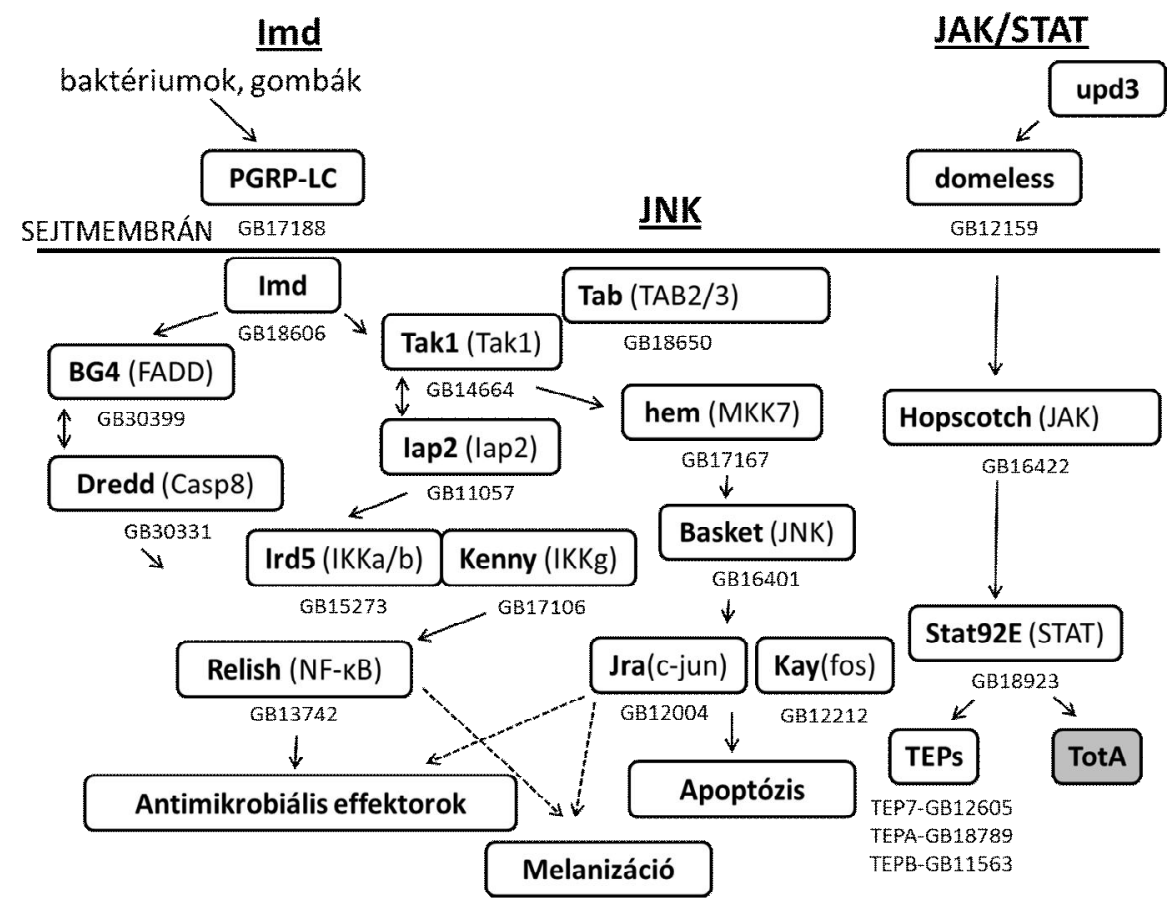

3. ábra A mézelő méhben azonosított immungének az Imd, JNK és JAK/STAT jelátviteli útvonalakban (Evans és mtsai., 2006 után módosítva).

A Toll jelátviteli útvonalat többnyire a Gram-pozitív, lizin-típusú peptidoglikánnal rendelkező baktériumok, valamint a gombák aktiválják. Az útvonal kiindulási pontja a proteolitikus kaszkád során hasítódó citokin-szerü Spätzle molekula (SPZ) (Arnot és mtsai., 2010), amely kötődésével dimerizálja a Toll receptort (Schneider és mtsai., 1994). A dimerizált receptor citoplazmatikus doménjéhez a MyD88 adapter fehérje kötődik, így a Tube és Pelle kináz is képes a komplexhez kapcsolódni. A foszforiláció eltávolítja a Cactus molekulát a Dorsal fehérjéről, amelynek NLS szekvenciája elérhető lesz, így a sejtmagba jutva szabályozza az antimikrobiális peptidek génjeinek átírását (Lindsay és Wasserman, 2014) (4. ábra). 


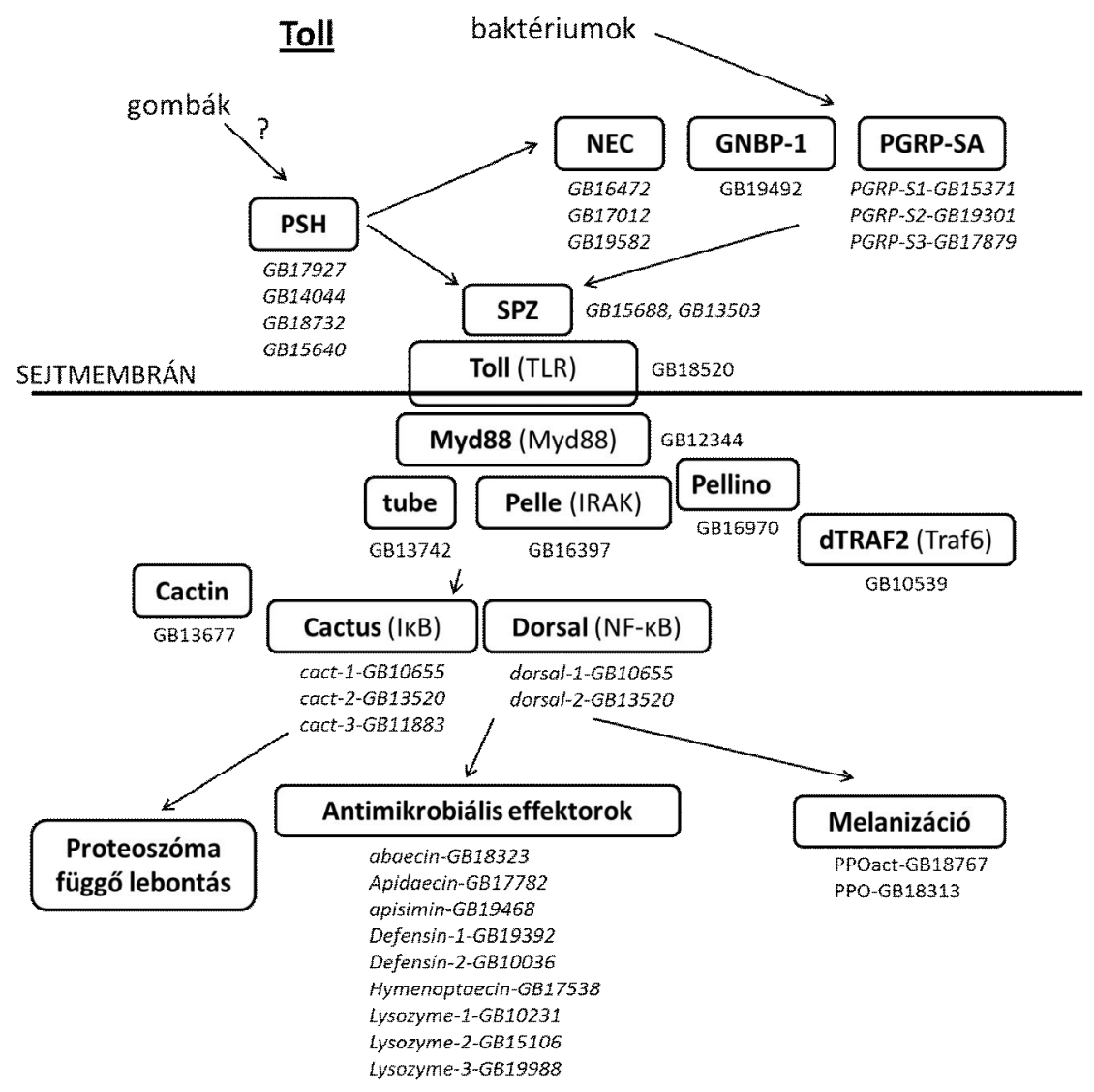

4. ábra A mézelő méhben azonosított immungének a Toll jelátviteli útvonalban (Evans és mtsai., 2006 után módosítva).

A jelátviteli útvonalak az antimikrobiális peptidek termelésén kívül a melanizációs folyamatokat is szabályozzák. Ízeltlábúakban a szeptikus sérülés és a parazitoid darazsak szúrása a sérülés helyén melanin szintézisét váltja ki (Tang, 2009). A melanizáció során a profenoloxidáz (PPO) enzimatikus hasítást követően aktív fenoloxidázzá alakul és a fenolok oxidációját katalizálja melaninná poimerizálódó kinonokká (Cerenius és Söderhäll, 2004, Cerenius és mtsai, 2008). D. melanogaster-ben három PPO-t azonosítottak: a kristálysejtek termelte PPO1 és a PPO2 a sérülést követő melanizációs folyamatokat (Dudzik és mtsai., 2015), míg a lamellociták által termelt PPO3 a PPO2-vel együttmüködve a tokképzés során bekövetkező melanizációt aktiválja (Irving és mtsai., 2005, Nam és mtsai., 2008) (5. ábra). 


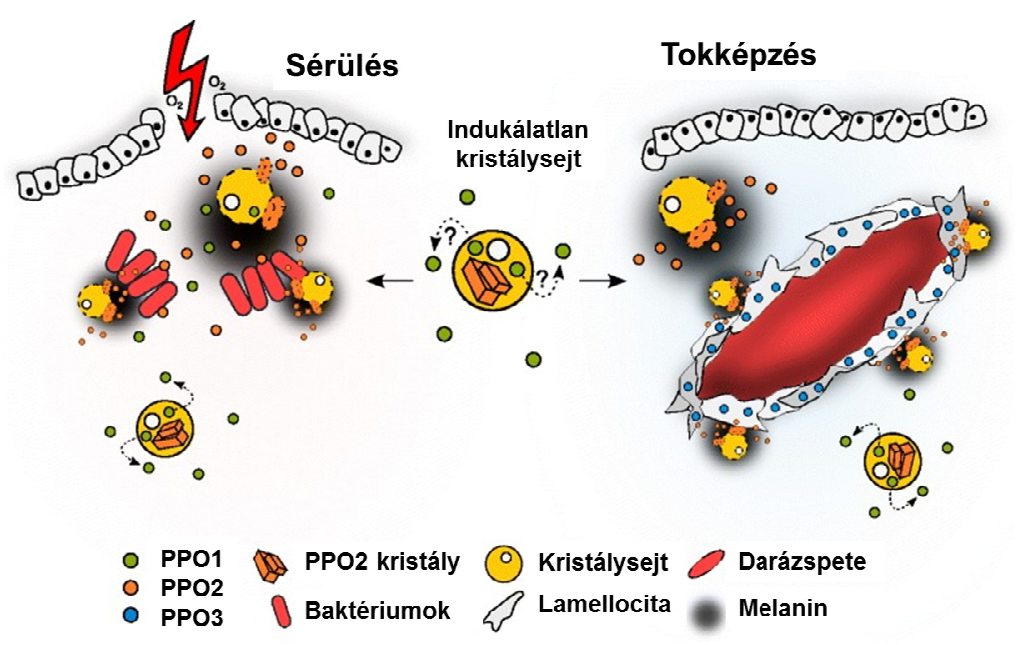

5. ábra D. melanogaster fenoloxidáz aktivitása (Dudzik és mtsai., 2015 után módosítva).

A rovarok kutikula sérülése során a melanizációs folyamatok mellett hemolimfa koagulációhoz vezető kaszkád reakció is aktiválódik, amelynek során a hemolimfa megalvad és elzárja a sebet, az alvadék hálózatos struktúrája meggátolja további kórokozók szervezetbe történő bejutását és szaporodását (Bidla és mtsai., 2005, 2009, Krautz és mtsai., 2014, Theopold és mtsai., 2014). Az ízeltlábúakban azonosított alvadási faktorok egymással szerkezeti és funkcionális hasonlóságot mutatnak. D. melanogaster-ben a hemolimfa alvadékban a hemociták által termelt von Willebrand faktor homológ domaineket tartalmazó hemolektin fehérje van a legnagyobb mennyiségben jelen (Goto és mtsai., 2001, Iwanaga és mtsai., 1998, Jiravanichpaisal és mtsai., 2006, Lesh és mtsai., 2007, Loof és mtsai., 2011, Theopold és mtsai., 2004).

\section{I.4.2 Sejt-közvetítette immunitás}

A sejt-közvetítette immunitás effektor sejtjei a vérsejtek, azaz hemociták, amelyek a mikroorganizmusok fagocitózisát végzik, valamint a nagyobb méretü kórokozókat tokképzés során pusztítják el (Hoffmann és mtsai., 1999, Vilmos és Kurucz, 1998). A rovarok közül a legrészletesebben az ecetmuslica vérsejtképződését és vérsejt populációit tanulmányozták. Drosophila-ban a keringő vérsejtek több mint 95\%-át a fagocitáló kis kerek sejtek, a plazmatociták teszik ki, amelyek a bekebelezés mellett extracelluláris mátrix fehérjéket és antimikrobiális peptideket is termelnek (Martinek és mtsai., 2008, Samakovlis és mtsai., 1990, Ulvila és mtsai., 2011). A kristálysejtek a plazmatocitákhoz hasonló morfológiájú sejtek, de citoplazmájuk profenoloxidáz kristályokat tartalmaz, amelyek a melanizációban és a koagulációban vesznek részt (Rizki és Rizki, 1959, Bidla és mtsai., 2009). A lamellociták nagy kiterült vérsejtek, amelyek immunindukciót követően (sérülés, darázsfertőzés) jelennek meg a keringésben és a plazmatocitákkal együtt 
többrétegű tokot hoznak létre a nagyobb méretű testidegen anyagok körül (Carton és Nappi, 1997).

A vérsejtek vérsejtképző szövetekben differenciálódnak az egyedfejlődés során. D. melanogaster lárvában három fö vérsejtkompartmentum különíthető el: a keringés, a szesszilis szövet és a központi nyirokszerv (Lanot és mtsai., 2001, Sorrentino és mtsai., 2002, Zettervall és mtsai., 2004). A keringésben a vérsejtek szabadon áramlanak a hemolimfában a szívcső periodikus összehúzódásainak megfelelően anterior irányban (Tao és Schulz, 2007). A szesszilis szövet a lárva testüregének falához tapadó, a lárva szegmenseinek megfelelő vérsejtkompartmentumokból áll (Lanot és mtsai., 2001, Márkus és mtsai., 2009, Zettervall és mtsai., 2004). A központi nyirokszerv a szívcső mentén elhelyezkedő páros lebenyes szerv, amelynek első lebenye funkcionális zónákra osztható (Jung és mtsai., 2005, Krzemien és mtsai., 2007, 2010, Roehrborn, 1961). Számos rovarfajban leírtak a központi nyirokszervhez hasonló, a szívcső közelében elhelyezkedő struktúrát. A kétfoltú tücsök (Gryllus bimaculatus) lárváinak 2. és 3. szelvényében a szívcső két oldalán párban (Hoffmann, 1970), selyemhernyóban (Bombyx mori) a testfal belső felületéhez tapadva az elülső és hátulsó szárnydiszkuszok közelében (Han és mtsai., 1998) található. A keleti vándorsáskában (Locusta migratoria) a szívcső körüli sejtrétegből differenciálódnak a vérsejtek (Hoffmann, 1970), kék dongólégyben (Calliphora erythrocephala) a szívcső poszterior végében található a lárvális vérképzőszerv (Hoffmann 1979), cifrarákban (Orconectes limosus) az előbél anterior végén helyezkedik el egy több sejtrétegből álló vérsejtképző kompartmentum (Böhm és Gersch, 1983). Mézelő méhben eddig még nem azonosítottak hasonló lárvális vérsejtképző kompartmentumot.

A fagocitózis a törzsfejlődés során konzerválódott folyamat a patogén mikroorganizmusok eltávolítására (Ulvila és mtsai., 2011). A folyamat során a fagocitálandó részecskék felismerése és megkötése a fagocitáló vérsejtek sejtfelszíni receptorainak közremüködésével történik. Ezek a mintázatfelismerő receptorok az evolúció során konzerválódtak és a patogénekre általánosan jellemző molekuláris mintázatokat (PAMP) érzékelik (Kurata, 2014). A fagocitáló sejtek miután felismerték a testidegen részecskéket megkötik, bekebelezik és a sejten belüli lizoszómákban lebontják azokat. (Shim és mtsai., 2010, Ulvila és mtsai., 2011). A fagocitózisreceptorok több csoportba sorolhatók, amelyek közül Drosophila-ban az epidermális növekedési faktor (EGF) doménhez hasonló NIM domént tartalmazó receptorok közül a NimC1 a Gram-negatív és Gram-pozitív baktériumok felismerését, az Eater a Gram-pozitív baktériumok, a Draper a Gram-pozitív Staphillococcus aureus baktérium fagocitózisában játszik szerepet 
(Hashimoto és mtsai., 2009, Kocks és mtsai., 2005, Kurucz és mtsai., 2007a). A NIM domént tartalmazó fehérjék a Nimrod fehérjecsalád tagjai. A fehérjéket kódoló gének közül a $\operatorname{nim} A, \operatorname{nim} B, \operatorname{nim} C$ és draper gének homológja mézelö méhben is megtalálható (Somogyi és mtsai., 2010).

A tokképzés a mikroorgasnizmusoknál nagyobb méretű kórokozók, mint például a fürkészdarazsak petéjének, elhatárolása a gazdaszervezettől. A tokképzés ecetmuslicában részletesen tanulmányozott folyamat, amely hasonló az emlősök granulóma képzéséhez (Helming és Gordon, 2009). A parazita a lárva testüregében helyezi el petéjét, majd annak szöveteivel táplálkozva fejlődik és elpusztítja azt. A gazdaszervezet érzékeli a testidegen anyagot, a lárvában speciális vérsejttípus differenciálódik, amely egy többrétegü melanizált tokot alkotva határolja el a parazitát a szervezettől (Nappi és mtsai., 2004). Méheknél csupán néhány olyan fajt azonosítottak, amely kifejlett egyedek potrohában helyezi el petéjét, de arról nincsenek adatok, hogy ez a fertőzés kivált-e valamilyen immunválaszt a gazdaszervezetben (Core és mtsai., 2012, Dutto és Ferrazzi, 2014, Menail és mtsai., 2016).

\section{I.4.3 A rovarok sejt-közvetítette immunválaszának vizsgálata}

A rovarok vérsejtjeit elöször morfológiai, hisztokémiai és funkcionális jellemzőik alapján csoportosították (Gupta, 1979, Jiravanichpaisal és mtsai., 2006, Lavine és Strand, 2002). Csoportunkban elsőként vérsejt specifikus, monoklonális ellenanyagok előállításával immunológiai markereket azonosítottak, valamint vérsejt specifikusan működő meghajtó elemeket hoztak létre D. melanogaster-ben, amelyek segítségével a vérsejt alpopulációk in vivo és ex vivo egyaránt azonosíthatóvá váltak (Csordás és mtsai., 2014, Kurucz és mtsai., 2003, Kurucz és mtsai., 2007a, Kurucz és mtsai., 2007b, Rus és mtsai., 2006, Vilmos és mtsai., 2004). D. melanogaster-ben a különböző vérsejttípusok elkülönítésére és differenciálódásuk szabályozásának vizsgálatához in vivo transzgenikus konstrukciókat alakítottak ki, amelyek segítségével az immunválaszban szerepet játszó géneket azonosítottak, valamint olyan mutánsokat hoztak létre, amelyek melanotikus tumorokat hordoznak (Braun és mtsai., 1997, Honti és mtsai., 2009, Rodriguez és mtsai., 1996, Shrestha és Gateff, 1986).

Más Hymenoptera fajokhoz hasonlóan (Amaral és mtsai., 2010, Manfredini és mtsai., 2008) a mézelő méh vérsejtjeit is először morfológiai jegyeik alapján csoportosították. A mézelő méh vérsejtjeinek morfológiai vizsgálatait kiegészítették fluoreszkáló festékekkel jelölt lektinek kötési képességének meghatározásával (deGraaf és mtsai., 2002, Marringa és mtsai., 2014), valamint hisztokémiai festődésük (El-Mohandes 
és mtsai., 2010, Richardson és mtsai., 2018) és a sejtek szilárd fázishoz történő kitapadásának, szétterülésének és funkciójának meghatározásával (Negri és mtsai., 2014).

\section{I.4.4 A mézelő méh vérsejttípusai}

Elektronmikroszkópos vizsgálatok segítségével a mézelő méh vérsejttípusait morfológiai jegyek alapján különítették el a vérsejtek 90\%-át alkotó plazmatocitákra, amelyeket négy altípusra bontottak (P1-P4), valamint prohemocitákra, granuláris sejtekre, önocitákra és koagulocitákra (Van Steenkiste, 1988). Ezt a nevezéktant alkalmazva deGraaf és munkatársai a kifejlett dolgozók vérsejtjeinek morfológiai jegyeken alapuló elkülönítését kiegészítették fluoreszcensen jelölt lektinek mikroszkópos és áramlási citometriás vizsgálatával. Elkülönítették az alacsony fluoreszcencia intenzitású granuláris sejteket és két magas intenzitású plazmatocita populációt. Az egyik populációban az egész sejt festődött, míg a másik populáció granuláris festődést mutatott. A prohemociták egyáltalán nem festődtek. Megállapították, hogy a lektinkötés nem alkalmas a plazmatociták és a granulociták áramlási citometriával történő elkülönítésére, mivel hasonló fluoreszcencia intenzitást mértek mindkét csoportnál (deGraaf és mtsai., 2002). Ezt a módszert alkalmazva később Marringa és munkatársai permeabilizált sejteket, plazmatocitákat és mikropartikulumokat különítettek el (Marringa és mtsai., 2014). Hisztokémiai festéssel az alábbi vérsejttípusokat azonosították dolgozó lárvákban: prohemociták, különböző típusú plazmatociták, granulociták, önociták és koagulociták. A prohemociták általában kis kerek sejtek az egész sejtet betöltő centrális sejtmaggal. A plazmatociták különböző méretűek és alakúak (kerek, ovális, szabálytalan), citoplazmájuk vakuólumban gazdag, a keringő vérsejtek 90\%-át alkotják. A granulociták kerek sejtek, centrálisan elhelyezkedő viszonylag kis sejtmaggal, jellemzően szemcsés citoplazmával. A koagulociták nagy kerek sejtek kis sejtmaggal. Az önociták nagy ovális sejtek, a sejtmérethez képest kis excentrikus elhelyezkedésü sejtmaggal rendelkeznek. A binukleált sejtek azok a sejtek, amelyeknél nem fejeződött be a mitózis. A prohemociták, koagulociták, önociták és binukleált sejtek a méhek diétájától függően nem mindig vannak jelen a keringésben (El-Mohandes és mtsai., 2010). Negri és munkatársai 5. stádiumú lárvákat és frissen kikelt dolgozókat vizsgáltak. A vérsejtek kitapadását, szétterülését és funkcióját vizsgálva in vitro kísérletekben, a lárvában két, míg a dolgozóban négy sejttípust különítettek el. A lárvában egyrészt olyan kerek sejteket (L5-1) találtak, amelyek nem mutatnak helyváltoztatást, másrészt nagy kiterült sejteket (L5-2) is azonosítottak, amelyek a kiterülésük során pszeudopódiumokat növesztenek. A kifejlett dolgozókban 
azonosított első sejttípus (W-1) nagymértékben képes szilárd fázishoz kitapadni és granulumokat képezni, míg a második típus (W-2) sejtfelszíne sima és kiterülés során pleumorfikus lesz. A harmadik (W-3) és negyedik (W-4) csoport sejtjei nem tapadnak ki, hanem úsznak a szuszpenzióban, a negyedik csoport sejtjei képesek filopódiumokat is növeszteni.

Mivel a korábban meghatározott vérsejttípusok differenciálódási vonalai nem ismertek, valamint a különbözö laboratóriumokban különböző módszerekkel azonosított sejttípusok morfológiai jellemzői és funkciói nehezen összevethetők szükségessé vált egy olyan specifikus molekuláris módszer kidolgozása, amely a funkciójukban különböző vérsejttípusokat képes elkülöníteni egymástól (deGraaf és mtsai., 2002, Negri és mtsai., 2016).

\section{I.4.5 A mézelő méh sejt-közvetítette immunválasza a kasztok egyedfejlődése és a fertőzések során}

A mézelő méh egyedfejlődési stádiumaiban nemcsak egymástól különböző vérsejttípusokat azonosítottak (Negri és mtsai., 2014), eltérés van a vérsejtek számában és fenoloxidáz aktivitásában is. Az egyedfejlődés során lárvális és báb stádiumokban magasabb a vérsejtek száma, mint a kifejlett egyedekben, a fenoloxidáz aktivitás mindhárom kasztban folyamatosan emelkedik (Laughton és mtsai., 2011, Schmid és mtsai., 2008, Wilson-Rich és mtsai, 2008). Az áttelelő dolgozókban megemelkedik a vérsejtek száma (Burritt és mtsai., 2016). Hystad és munkatársai leírták, hogy a fiatalabb gondozó méhek vérsejtjeinek fagocitáló képessége magasabb, mint az idősebb gyüjtő és az áttelelő méheké (Hystad és mtsai., 2017).

Csupán néhány méhparazitáról és fertőző mikroorganizmusról mutatták ki, hogy hatással van a mézelő méh sejt-közvetítette immunválaszára. Marringa és munkatársai leírták, hogy a permeabilizált sejtek és a plazmatociták aránya magasabb az atkafertőzött kolóniákban (Marringa és mtsai., 2014). Serratia marcescens sicaria fertőzés során kimutatták, hogy csökken a vérsejtek száma a nem fertőzött egyedekhez képest (Burritt és mtsai., 2016). Spiroplasma melliferum fertőzés esetén megemelkedik a granulociták majd a plazmatociták aránya a nem fertőzött egyedekhez képest (Yang és mtsai., 2017).

Neonikotinoid kezelés hatására csökken a vérsejtek száma, a melanizációs aktivitás és a hemolimfa antimikrobiális aktivitása mind a dolgozókban, mind a méhanyákban (Brandt és mtsai., 2016, 2017). 


\section{Célkitüzések}

Globálisan súlyos ökológiai és gazdasági károkat eredményez a biotikus és abiotikus faktorok által okozott tömeges méhpusztulás. A méhpusztulás okainak részletes feltárásához járulhat hozzá a méhek természetes védekezési folyamatainak és immunrendszerének megismerése. A méhek szociális viselkedéséből adódó alternatív védekezési stratégiákat, valamint az egyedi immunválasz humorális folyamatait már részletesen tanulmányozták, azonban a sejt-közvetítette immunválasz molekuláris folyamatairól keveset tudunk, ezért kísérleteinkben célul tüztük ki:

1. a mézelö méh vérsejtjeinek és sejt-közvetítette immunrendszerének molekuláris szintű jellemzésére alkalmas vizsgálati rendszer létrehozását,

2. a mézelő méh lárvák és dolgozók vérsejtjein megnyilvánuló markerekkel kapcsolódó monoklonális ellenanyagok előállítását, a vérsejt alpopulációk jellemzését,

3. az azonosított vérsejt alpopulációk szerepének meghatározását a különböző kasztokban és az egyedfejlődés egymást követő szakaszaiban,

4. az azonosított molekuláris markerek részletes jellemzését és a kódoló gének meghatározását,

5. a szervezet első védelmi vonalában szerepet játszó fehérjék megismerését, a fizikai védekezést szolgáló kutikulában megnyilvánuló D. melanogaster Vajk fehérjék homológjainak vizsgálatát a mézelő méhben. 


\section{Anyagok és módszerek}

\section{III.1 Reagensek és oldatok}

\section{Oldatok:}

- I. fixáló oldat: $50 \%$ metanol, $12 \%$ ecetsav, $0,019 \%$ formaldehid desztillált vízben

- II. fixáló oldat: $50 \%$ metanol, $12 \%$ ecetsav desztillált vízben

- AEC-oldat: 0,05\% 3-amino-9-etilkarbazol törzsoldat (Sigma Aldrich) 0,003\% $\mathrm{H}_{2} \mathrm{O}_{2}$ nátrium-acetát pufferben $(2 \mathrm{mM}$, $\mathrm{pH} 4,6)$

- Anti-egér IgG másodlagos ellenanyag: DAKO 1:5000 1\% BSA-TBS-ben

- Borát-puffer: 0,2 $\mathrm{M}$ bórsav/ $\mathrm{NaOH}$ pH 9,0

- DAPI: 4,6-diaminido-2-fenillindol, Sigma Aldrich, 20 mg/ml 1:10000 0,1\% PBSBSA-ban

- DMP: dimetil-pimelimidát-dihidroklorid, Sigma Aldrich, 5,2 $\mathrm{mg} / \mathrm{ml}$ Borátpufferben

- $\quad$ DTT: 1,4-dithiothreitol, Thermo Scientific

- Drosophila Ringer oldat: $111 \mathrm{mM} \mathrm{NaCl}, 1,87 \mathrm{mM} \mathrm{KCl}, 2,38 \mathrm{mM} \mathrm{NaHCO}, 1,1$ $\mathrm{mM} \mathrm{CaCl}_{2}, 0,84 \mathrm{mM} \mathrm{NaH}_{2} \mathrm{PO}_{4}$

- ECL Plusz Western blot detektáló reagens: GE Healthcare

- Előhívóoldat: $6 \mathrm{~g} \mathrm{Na}_{2} \mathrm{CO}_{3}, 40 \mu \mathrm{l} 1 \% \mathrm{Na}_{2} \mathrm{~S}_{2} \mathrm{O}_{3}, 53 \mu \mathrm{l} 35 \%$ formaldehid $100 \mathrm{ml}$ desztillált vízben

- $\quad$ FBS: fetal bovine serum, GIBCO

- Fluoromont médium: Southern Biotech, Fluoromont G

- Glicerol-oldat: $85 \%$ glicerol, $0,1 \mathrm{M}$ TRIS

- HAT: Sigma Aldrich, $5 \mathrm{mM}$ hipoxantin, 0,02 $\mathrm{mM}$ aminopterin, 0,8 $\mathrm{mM}$ timidin

- karbonát-bikarbonát puffer: $0,25 \mathrm{M}, \mathrm{pH} 9,0$

- KRPMI médium: 5\% marha szérummal kiegészített RPMI-1640 szövettenyésztő táptalaj

- Lízis puffer: $50 \mathrm{mM}$ Tris/HCL pH 8,0 (Reanal), $150 \mathrm{mM} \mathrm{MgCl}_{2}$ (Reanal), $1 \%$ NP40 (Fluka), 5 mM EDTA (Sigma), 0,1\% SDS (Sigma) 10 mM PMSF (Sigma), proteáz inhibitor koktél (Roche)

- $\quad$ Nátrium-acetát: $2 \mathrm{mM}, \mathrm{pH} 4,6$ 
- PBS-oldat: foszfátokkal pufferelt fiziológiás sóoldat, $0,13 \mathrm{M} \mathrm{NaCl}, 7 \mathrm{mM}$ $\mathrm{Na}_{2} \mathrm{HPO}_{4}, 3 \mathrm{mM} \mathrm{NaH} \mathrm{PO}_{4}, \mathrm{pH} 7,4$

- PEG 1540: polietilén-glikol, Sigma Aldrich

- PTU: 1-fenil-2-tiourea, Sigma, Aldrich

- RPMI 1640: szövettenyésztő tápfolyadék, GIBCO

- Schneider's médium: szövettenyésztő tápfolyadék, Sigma Aldrich

- SDS mintapuffer: 15,6 mM Tris/ $\mathrm{HCl} \mathrm{pH} 6,8,6,25 \%$ glicerol, 0,5\% SDS, 0,003\% brómfenolkék

- TBS oldat: $10 \mathrm{mM}$ Tris/ $\mathrm{HCl} \mathrm{pH} 7,5,150 \mathrm{mM} \mathrm{NaCl}$

- transzfer puffer: $25 \mathrm{mM}$ Tris, $90 \mathrm{mM}$ glicin, $20 \%$ metanol

\section{Ellenanyagok:}

- Alexa Fluor 488 fluoreszcens festékkel konjugált anti-egér Ig: Molecular Probes, $2 \mathrm{mg} / \mathrm{ml} \mathrm{1:1000} \mathrm{0,1 \%} \mathrm{PBS} \mathrm{BSA-ban}$

- Alexa Fluor 568 fluoreszcens festékkel konjugált anti-egér Ig: Molecular Probes, $2 \mathrm{mg} / \mathrm{ml} \mathrm{1:1000} \mathrm{0,1 \%} \mathrm{PBS} \mathrm{BSA-ban}$

- Biotinált kecske-anti-egér Ig ellenanyag: DAKO, 1,46 mg/ml 1:500 0,1\% PBSBSA-ban

- Monoklonális ellenanyagok: 1 . táblázat

- Streptavidin HRP: DAKO, 0,85 mg/ml 1:300 0,1\% PBS-BSA-ban

- T2/48: humán leukocita antigén elleni ellenanyag, $0,5 \mathrm{mg} \mathrm{ml}^{-1}, 0,15 \mathrm{M} \mathrm{NaCl}$ 


\section{III.2 A kísérleti egyedek tartási körülményei}

A méheket magyar szabvány szerinti ún. Tamási rendszerü 1/2 Boconádi, egyenlő lépes rakodó-kaptárakban tartjuk, amelyben a keretek külmérete $42 \times 18 \mathrm{~cm}$ és fiókonként 10 keretnyi lépet tartalmaznak. Az alsó két fiók ( 2 x 10 keretnyi lép) szolgál „fészek” gyanánt, vagyis itt található az anya és szaporulata. A fészek felett anyaráccsal van elválasztva a szükség szerint 1-3 fiókból álló „mézkamra”, amelybe a család a tartalék mézet gyüjti. A méheket tavasztól nyár végéig vándoroltatjuk, azaz lehetőség szerint az éppen virágzó „méhlegelőre” szállítjuk, amely április közepén repce, május közepén akác, június elején szíriai selyemkóró, és végül, július elején, napraforgó. Az állományt az akác és a napraforgó méz elvétele után amitráz tartalmú atkaölő szerrel, novemberben pedig oxálsavval kezeljük a Varroa atka ellen. A méhek az utolsó gyűjtés után náluk hagyott napraforgó mézen (kb. 5-10 kg) és az arra etetett répacukor-szirupon (kb. 5-10 kg) telelnek, két fiókon.

Neonikotinoid kezelés során a kezelt családokat tiometoxannal napraforgó vetőmaggal csávázott méhlegelőn helyeztük el.

Amitráz kezelés során a méheket 6 alkalommal kezeltük 3 naponta 0,299 g amitrázzal családonként minden alkalommal, amelyet petróleummal keverve ködöléssel juttattunk be a kaptárakba.

A kísérletben felhasznált kifejlett egyedeket begyüjtésük napján dolgoztuk fel, a lárvákat Drosophila Ringer oldattal mostuk ki a lépekből és begyüjtésüket követően három órán belül felhasználtuk. A kísérleti egyedek nem mutatták fertőzések, betegségek tüneteit.

A kísérletek során felhasznált Oregon-R és l(3)mbnl Drosophila törzseket $25^{\circ} \mathrm{C}$-on, standard Drosophila táptalajon tenyésztettük, a B. mori lárvákat, a Szent István Egyetem, Állatorvostudományi Karának, Virológiai Kutatócsoportja biztosította. Az egyedeket $25^{\circ} \mathrm{C}$-on tartottuk és eperfa levéllel etettük.

\section{III.3 Vérsejtek gyüjtése}

A mézelő méh lárva vérsejtjeinek gyüjtése elött a lárvákat Drosophila Ringer oldatban lemostuk és jéggel hütött üvegtálba helyeztük. Fecskendő segítségével átszúrtuk a kutikulát, majd egy másik helyen PTU-t, 5\% FBS-t tartalmazó Schneider’s médiumot fecskendeztünk a lárvába, így tejszerü homogén, vérsejteket tartalmazó hemolimfát nyertünk, amelyet jégen tároltunk. 
A mézelő méh kifejlett egyedeket $\mathrm{CO}_{2}$-dal kábítottuk. Egy fecskendővel $50 \mu 1$ PTU-t, 5\% FBS-t tartalmazó Schneider's médiumot fecskendeztünk az egyed torán keresztül a testüregbe, ezt követően egy tü segítségével megsebeztük a potrohát és a potrohon keresztül cseppenként távozó hemolimfát jégen álló 1,5 ml-es Eppendorf csőben gyüjtöttük.

Az ecetmuslica lárvákat jégre helyezett U aljú 96 lyukú lemezen és $360 \mu 1$ PTU-t, 5\% FBS-t tartalmazó Schneider's médiumban csipesszel boncoltuk és véreztettük.

A selyemhernyó lárvák kutikuláját tű segítségével felsértettük, majd egy másik helyen PTU-t, 5\% FBS-t tartalmazó Schneider's médiumot fecskendeztünk a lárvába, a hemolimfát jégen, cseppenként gyüjtöttük.

\section{III.4 Ellenanyagok előállítása}

$\mathrm{BALB} / \mathrm{c}$ egereket immunizáltunk háromszor, minden alkalommal $10^{6} \mathrm{~A}$. mellifera lárvából vagy kifejlett egyedből nyert vérsejttel $1 \mathrm{ml}$ Drosophila Ringer oldatban, 3 hetes időközökkel. Az immunizálás után sejtszuszpenziót készítettünk az egerek lépéből RPMI-1640 szövettenyésztő tápfolyadékban. Az utolsó immunizálást követő 3. napon a lépsejteket Sp2/0 sejtekkel fúzionáltattuk PEG-1540 jelenlétében, majd lapos aljú 96 lyukú lemezekbe szétosztottuk. A hibridómákat HAT médiumban szelektáltuk. A vérsejtek jellemzésére a monoklonális ellenanyagokat tartalmazó hibridóma sejt felülúszót használtunk (Köhler és Milstein, 1975, Köhler és Milstein, 1976, Kurucz és mtsai., 2007b). $\mathrm{Az}$ ellenanyagok izotípusát IsoStrip Mouse Monoclonal Antibody Isotyping Kit-tel határoztuk meg.

\section{III.5 Immunhisztokémiai vizsgálatok}

Immunhisztokémiai vizsgálatokkal a vérsejteken és a szöveteken határoztuk meg az ellenanyagok által felismert molekuláris markerek kifejeződését. A kísérleteket szobahőmérsékleten végeztük.

A vérsejtek vizsgálata:

A vérsejteket 12 lyukú mikroszkópos tárgylemezre tapasztottuk 60 percen át 5\% FBS-t és PTU-t tartalmazó Schneider's médiumban. A sejteket acetonnal fixáltuk 6 percig, levegőn szárítottuk, majd 0,1\% PBS-BSA oldattal telítettük 20 percen keresztül. A mintákat 60 percig inkubáltuk a hibridóma felülúszóval, és három alkalommal 5 percig mostunk PBS oldattal, biotinált kecske-anti-egér ellenanyaggal inkubáltuk 45 percig, majd 
háromszor 5 percig mostuk PBS oldattal. Ezt Streptavidin HRP kezelés követte 45 percig majd újból háromszor 5 perces PBS-es, ezt követően háromszor 3 perces nátrium-acetátos mosás. A reakciót AEC oldattal tettük láthatóvá, majd háromszor 5 perces desztillált vizes mosás következett. A sejtmagok jelölésére 10 percig DAPI oldattal inkubáltuk a mintákat, majd háromszor 5 percig mostuk desztillált vízben. A lemezeket glicerol oldattal fedtük és Zeiss Axioscope mikroszkópban, Nomarski, fáziskontraszt és fluoreszcens objektívvel vizsgáltuk.

Szövetek vizsgálata:

A testfestéshez szétbontottuk a szöveteket Schneider's, 5\% FBS oldatban, 6 percig fixáltuk acetonnal, majd 20 percig telítettük 0,1\% PBS-BSA, Triton X oldatban. Hozzáadtuk a hibridóma felülúszót 60 percre. A mintákat három alkalommal 10 percig mostuk PBS oldatban, biotinált kecske-anti-egér Ig ellenanyaggal inkubáltuk 45 percig, majd háromszor 10 percig mostuk PBS oldatban, ezután Streptavidin HRP-vel inkubáltuk 45 percen keresztül és háromszor 10 percig PBS oldatban, háromszor 3 percig pedig nátrium-acetáttal mostuk. A reakciót AEC oldattal tettük láthatóvá, majd háromszor 10 percig mostuk a mintákat desztillált vízzel. A sejtmagok jelölésére 10 percig DAPI oldattal inkubáltuk a mintákat, majd háromszor 10 percig desztillált vízzel mostuk. A lemezeket glicerol oldattal fedtük és Zeiss Axioscope mikroszkópban, fáziskontraszt, Nomarski és fluoreszcens optikával vizsgáltuk.

\section{III.6 Indirekt immunfluoreszcens vizsgálatok}

Indirekt immunfluoreszcens módszerrel vizsgáltuk a markereknek a vérsejteken és szöveteken történő kifejeződését. A kísérleteket szobahőmérsékleten végeztük. A vérsejtek esetében a kísérlet menete a második ellenanyag hozzáadásáig megegyezik az immunhisztokémiai vizsgálat menetével (1sd.: III.5. Immunhisztokémiai vizsgálatok). Második ellenanyagként Alexa Fluor 488 vagy 568 fluoreszcens festékkel konjugált antiegér Ig reagenst használtunk, a sejtmagokat DAPI oldattal tettük láthatóvá. A lemezeket a második ellenanyaggal 45 percig inkubáltuk, majd vérsejtek esetén háromszor 5 percig, szövetek esetén háromszor 10 percig mostuk PBS oldatban. A mintákat Fluoremountmédiummal fedtük le, majd Zeiss Axioscope fluoreszcens mikroszkóppal és Olympos konfokális mikroszkóppal vizsgáltuk. 
Natív sejtek vizsgálata:

Natív sejtek vizsgálata során a vérsejteket szétosztottuk jégre helyezett, U aljú, 96 lyukú lemezekre. A kísérletet végig jégen hütve végeztük. Centrifugálás $\left(4^{\circ} \mathrm{C}, 1100\right.$ rpm, 5 perc) után a sejteket KRPMI médiumban megmostuk, majd 60 percig inkubáltuk a hibridóma felülúszóval, és három alkalommal mostunk KRPMI médiumban. Második ellenanyagként Alexa Fluor 568 fluoreszcens festékkel konjugált anti-egér Ig reagenst használtunk, a sejteket 45 percig inkubáltuk, majd háromszor mostunk KRPMI médiumban. A mintákat a tárgylemezre cseppentettük és Zeiss Axioscope fluoreszcens mikroszkópban vizsgáltuk.

\section{III.7 Permeabilizált, fixált vérsejtek áramlási citometriás vizsgálata}

A vérsejteket szétosztottuk jégre helyezett 96 lyukú U aljú lemezekre. A kísérletet végig jégen hütve végeztük. Centrifugálás $\left(4^{\circ} \mathrm{C}, 1100 \mathrm{rpm}, 5\right.$ perc $)$ után a mintákat 20 percig fixáltuk 2\%-os paraformaldehid oldattal, majd $0,1 \%$ Triton $\mathrm{X}, 0,2 \%$ BSA, $5 \%$ FBS oldattal 5 percig permeabilizáltuk. Centrifugálást követően a vérsejteket 60 percig inkubáltuk a hibridóma felülúszóval, és három alkalommal mostunk KRPMI médiumban. Második ellenanyagként Alexa Fluor 488 fluoreszcens festékkel konjugált anti-egér Ig reagenst használtunk 45 percig, majd háromszor mostuk a sejteket KRPMI médiumban. A minták fluoreszcencia intenzitását FACSCalibur áramlási citométerrel határoztuk meg.

\section{III.8 Baktériumok FITC jelölése}

A baktérium szuszpenziót $\left(\mathrm{OD}_{600}=1,5,10 \mathrm{ml}\right)$ lecentrifugáltuk (4200 x g, 20 perc, $4^{\circ} \mathrm{C}$ ), majd háromszor mostuk PBS-ben. A baktériumsejteket 1 órán át forrásban lévő

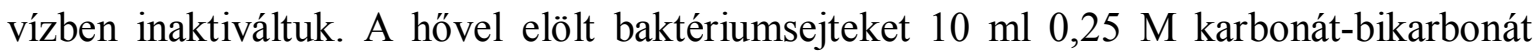
pufferben ( $\mathrm{pH}$ 9.0) szuszpendáltuk. Cseppenként a szuszpenzióhoz adva feloldottunk 0,5 mg FITC-ot $100 \mu \mathrm{l}$ DMSO-ban. Éjszakán át forgattuk $\left(4^{\circ} \mathrm{C}\right)$, majd tízszer mostuk PBS oldattal.

\section{III.9 A vérsejtek fagocitózisának vizsgálata}

A vérsejtek fagocitózisának in vivo vizsgálata során a lárvákba és a kifejlett egyedekbe $50 \mu 1$ FITC jelölt Gram-negatív Escherichia coli (SzMC 0582), Enterobacter cloacae (SzMC 21890), Gram-pozitív Staphylococcus aureus (SzMC 0579) (Szeged Mikrobiológiai Gyüjtemény, Szegedi Tudományegyetem) és Melissococcus pluton 
(Nemzeti Élelmiszerlánc-biztonsági Hivatal, Magyarország) baktériumot oltottunk, majd az egyedeket 45 perc után a fent leírtak szerint perfundáltuk.

\section{III.10 A hemolimfa alvadék vizsgálata}

Az alvadék vizsgálatához a „függő csepp” módszert alkalmaztuk (Bidla és mtsai., 2005). A méheket tárgylemezre véreztettük, amelyet megfordítva inkubáltunk nedves kamrában, szobahőmérsékleten, majd 20 perc elteltével egy másik tárgylemezt a hemolimfa csepphez érintettünk, hogy felfogjuk az alvadékot. A lemezeket 6 percig fixáltuk acetonnal az immunhisztokémiai és az indirekt immunfluoreszcens festésekhez.

\section{III.11 Az idegen test elhatárolásának vizsgálata a testüregtől}

A vérsejtek elhatároló képességének a vizsgálatához egy $0,08 \mathrm{~mm}$ átmérőjü, 75\%-os alkohollal sterilizált damil szálat füztünk keresztül a $\mathrm{CO}_{2}$-dal elaltatott kifejlett egyedek 3. és 4. potrohszelvénye között. A potroh feltárásával 3 óra múlva eltávolítottuk a szálat és tárgylemezre helyeztük, 2\%-os paraformaldehid oldattal 15 percig fixáltuk, majd a reakciót indirekt immunfluoreszcens festéssel tettük láthatóvá.

\section{III.12 Immunprecipitáció}

A hibridóma felülúszók 10 ml-ét $50 \mu 1$ Protein G Sepharose gyönggyel forgatva inkubáltuk $\left(25^{\circ} \mathrm{C}, 1\right.$ óra). A Protein G Sepharose gyöngyhöz kötött ellenanyagot háromszor mostuk borát-pufferrel, majd 30 percig forgattuk 5,2 mg/ml DMP oldattal. Ezután kétszer mostuk, majd 2 órán át forgattuk 0,2 M etanolaminnal ( $\mathrm{pH}$ 8), majd háromszor mostuk PBS-ben. A vérsejteket centrifugálással $\left(4^{\circ} \mathrm{C}, 1800 \mathrm{rpm}, 8\right.$ perc) izoláltuk a hemolimfából. A sejteket 1 órán át lízis pufferben tártuk fel. Összekevertünk $50 \mu \mathrm{l} 20 \%$-os Protein G Sepharose gyöngyöt $300 \mu \mathrm{l}$ vérsejtlizátummal és $4^{\circ} \mathrm{C}$-on, éjszakán át forgattuk. Ezután háromszor mostuk lízis pufferrel, SDS mintapufferrel inkubáltuk 1 órán át $56^{\circ} \mathrm{C}$-on, majd 5 percig forraltuk.

\section{III.13 Minta-előkészítés egész állatokból}

A különböző fejlődési stádiumú egész állatokat lízis pufferben homogenizáltuk, majd centrifugáltuk $\left(4^{\circ} \mathrm{C}, 13000 \mathrm{rpm}, 10\right.$ perc). A lizátumhoz 0,6 M DTT mintapuffert adtunk, majd 5 percig forraltuk. Western blot során mintánként $300 \mu$ g fehérjét juttattunk a zsebekbe. 


\section{III.14 Western blot}

A mintákat vérsejtek esetén 5-7,5\%-os poliakrilamid-gélben futtattuk nem redukáló körülmények között, az egész állatok vizsgálata során 10\%-os poliakrilamid-gélben futtattuk redukáló körülmények között. A fehérjéket polivinilidin fluorid (PVDF) membránra vittük át transzfer pufferben $30 \mathrm{~V}$-on, $4^{\circ} \mathrm{C}$-on, éjszakán át. A membránt $5 \%$ zsírmentes tejet tartalmazó TBS oldatban telítettük 1 órán át szobahőmérsékleten. Ezt követően a hibridóma felülúszókkal inkubáltuk rázatva 1,5 órán keresztül. Miután háromszor 10 percig mostuk TBS-sel, hozzáadtuk a HRPO konjugált anti-egér IgG másodlagos ellenanyagot. Három 10 perces TBS-es mosás után az előhívást ECL Plusz Western blot detektáló reagensekkel végeztük a gyártó utasításainak megfelelően, majd a reakciót röntgen filmen tettük láthatóvá.

\section{III.15 Ezüstfestés}

Az immunprecipitált fehérjéket 5-7,5\%-os grádiens gélben választottuk el elektroforézissel, nem redukáló körülmények között. Egy órán keresztül inkubáltuk a gélt az I. fixáló oldatban, majd háromszor 10 percig mostuk 50\%-os etanolban, ezt követően 2 percig előkezeltük $0,02 \%$ nátrium-tioszulfát oldattal. Desztillált vízzel öblítettük háromszor 20 másodpercig és 20 percig festettük sötétben frissen készített $0,2 \%$-os ezüstnitrát oldattal. Ismét háromszor 20 percig öblítettük desztillált vízzel, majd előhívóoldatba helyeztük. A reakciót két 20 másodperces desztillált vizes mosás követte, majd a II. fixáló oldatba helyeztük 10 percre.

\section{III.16 Duplaszálú RNS készítése (dsRNS) és RNS interferencia}

Kifejlett $A$. mellifera egyedekből RNS-t izoláltunk cDNS készítéséhez, amely egy 559 bp hosszú A. mellifera hemolectin (AmHml) specifikus szakasz amplifikálásához szolgált templátként. A reakcióban az 5'AGTTAATACGACTCACTATAGGAGTAACCATCAAGAAATAAC-3' és az 5'AGTTAATACGACTCACTATAGGGTCTTTCCTCTGGTTAAAAC-3' primerpárokat használtuk (T7 adapterszakasz aláhúzva). Kontrollként egy GFP-t tartalmazó pBluescript vektort használtunk, amelynek egy 542 bp-os szakaszát amplifikáltuk az 5'ATTTAATACGACTCACTATAGGTGCTTTTCAAGATACCCAGATC-3' és az 5'ATTTAATACGACTCACTATAGGTTCATCCATGCCATGTGTAATC-3’ primerpárral (T7 adapterszakasz aláhúzva). A fragmenteket a Bio Basic, EZ-10 Spin Column PCR 
Products Purification Kittel tisztítottuk, a DNS szekvencia vizsgálata pedig Invitrogen, BigDye Terminator v3.1 Cycle Sequencing Kittel és Applied Biosystems, 3500-Genetic Analyzerrel történt. A kiválasztott $h m l$ és GFP specifikus szakaszokból 1000 ng-ot használtunk templátként a dsRNS szintéziséhez, amelyet a Promega, T7 RiboMax Express RNAi System kittel végeztünk. A dsRNS-t géncsendesítésre használtuk fel Nunes és Simões (2009) módszerét alkalmazva. Második stádiumos lárvákat etettünk $1 \mu 1$ 1,5 $\mu \mathrm{g}$ AmHml-dsRNS-t tartalmazó cukoroldattal a lépsejtekben. Az egyik kontrollcsoportot $1 \mu 1$ 1,5 $\mu \mathrm{g}$ GFP-dsRNS-t tartalmazó cukoroldattal etettük, a másik kontrollcsoportot kezelés nélkül hagytuk. A fiasítást két órára elzártuk a családtól, majd visszahelyeztük őket a kaptárba az eredeti helyükre, hogy a lárvák természetes körülmények között fejlődhessenek a sejtek befedéséig. Az utolsó lárvastádiumot elérve megvizsgáltuk a lárvák vérsejtjeit indirekt immunfluoreszcenciával a 4E1 ellenanyagot használva, hogy megállapítsuk a pozitív sejtek arányát.

\section{III.17 Statisztikai elemzések}

$\mathrm{Az} A m H m l$ RNS interferencia kísérlet adatait egyszempontos varianciaanalízissel (ANOVA) értékeltük ki. A csoportok közötti szignifikanciát $(\mathrm{p} \leq 0.05)$ Tukay HSD teszttel állapítottuk meg SPSS Statistics 17.0 szoftvert használva.

A különböző kezelések és méhvonalak vérsejtjeinek vizsgálata során kapott adatokat Student's $t$-teszttel értékeltük. 


\section{Eredmények}

\section{IV.1 A vérsejteken kifejeződő immunológiai markerek csoportosítása}

A mézelő méh védekezőrendszerét vizsgáló laboratóriumokban még nem alakult ki egységes módszer a különböző vérsejttípusok meghatározására, ezért a vérsejteken sejttípus specifikusan megnyilvánuló molekulák azonosítására monoklonális ellenanyagokat $(\mathrm{mAb})$ állítottunk elő. Az ellenanyagok által felismert immunológiai markereket immunfluoreszcencia és immunhisztokémiai festéssel azonosítottuk, majd a lárva és adult hemolimfában keringő vérsejtjein kifejeződő mintázatuk alapján a D. melanogaster-ben korábban leírt markerekhez (Kurucz és mtsai., 2007b) hasonló módon csoportosítottuk. A kísérletek során összesen 3880 hibridóma ellenanyag termelését teszteltük, majd a méh vérsejtekkel és vérsejt alpopulációkkal reagáló sejttenyészetek közül 314-et kiválasztottunk, amiböl 72-t osztályoztunk (1. táblázat). Külön osztályokba soroltuk az összes hemocitán megnyilvánuló ún. pánhemocita markereket, valamint a különböző morfológiai jegyeket mutató hemocita alpopulációkon (deGraaf és mtsai., 2002): a plazmatocitákon (pl), az önocitákon (oe), valamint a granulocitákon (gr) és önocitákon megnyilvánuló markereket (1. táblázat). Ezek közül a markerek közül random módon kiválasztottuk és részletesen jellemeztük a 4E1 (6. ábra, a, b), 5A2, 6B3 plazmatocita-, a 2.28 (6. ábra, c, d), 4.19, 3B6 önocita- és a 4.70 (6. ábra, e, f), 4.78 granulocita-önocita markereket.

\begin{tabular}{|c|c|}
\hline Marker klaszter & Markerek \\
\hline pánhemocita & $\begin{array}{c}1.4 \mathrm{~A} 4,2.1,2.2,2.5,2.98,3.6,3.10,3.13,3.32 \\
3.34,3.35,3.61,5.1 \mathrm{~A} 5,5.1 \mathrm{~A} 12,5.3 \mathrm{~A} 6,5.3 \mathrm{E} 11 \\
5.4 \mathrm{~B} 6,5.4 \mathrm{~F} 5,5.5 \mathrm{C} 6,5.6 \mathrm{~B} 8,5.6 \mathrm{C} 2,5.6 \mathrm{D} 9,5.7 \mathrm{E} 12, \\
5.7 \mathrm{G} 10\end{array}$ \\
\hline plazmatocita & $\begin{array}{c}\text { 1.4F8, 6F10, 8D10, 2.91, 2.109, 3.31, 3.36, 3.39, } \\
\text { 3.42, 4E1, 5.1A1, 5.1A2, 5.1A4, 5.1G10, 5.1H10, } \\
\text { 5.3A9, 5.4C8, 5.6B4, 5.6C1, 5.6H10, 5.7D4, } \\
\text { 5.6E11, 5.6F5, 5A2, 6B3 }\end{array}$ \\
\hline önocita & $2.28,3 \mathrm{~B} 6,4.19,5.1 \mathrm{H} 5,5.2 \mathrm{~A} 5,5.2 \mathrm{~B} 1,5.6 \mathrm{G} 12$ \\
\hline granulocita-önocita & $4.70,4.78,5.4 \mathrm{H} 8,5 . \mathrm{D} 12,5.5 \mathrm{E} 8,5.5 \mathrm{H} 6$ \\
\hline
\end{tabular}

1. táblázat Molekuláris markerek csoportosítása. A további jellemzésre kijelölt markerek piros színnel vannak kiemelve. 

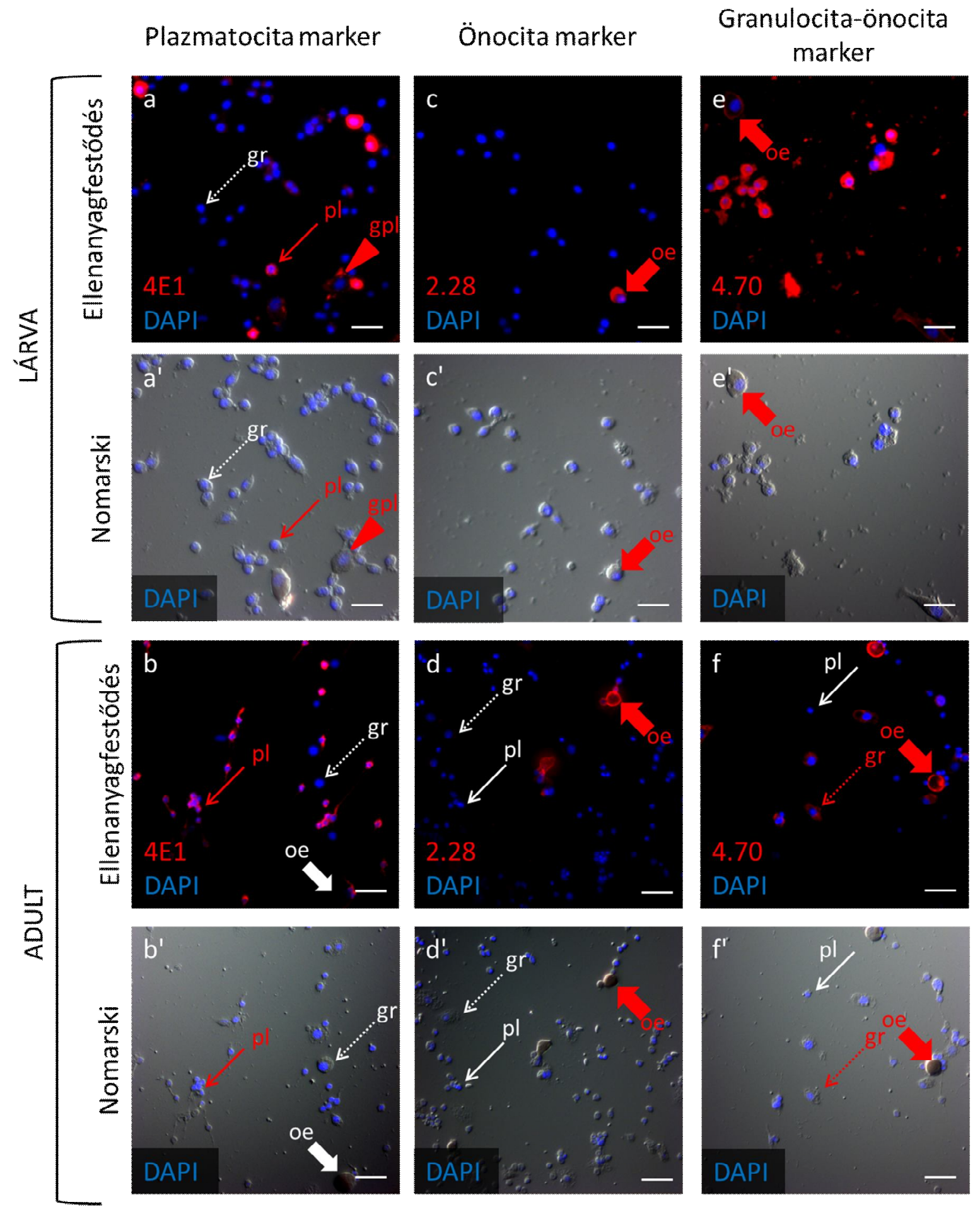

6. ábra A mézelő méh lárva és kifejlett egyed vérsejt alpopulációin kifejeződő molekuláris markerek kimutatása indirekt immunfluoreszcens festéssel. Harmadik stádiumú lárvából (L3) (a-c) és adultból (d-f) izolált, üveglemezhez tapasztott, acetonnal fixált hemociták festése 4E1, 2.28 és $4.70 \mathrm{mAb}$-okkal és anti-egér Alexa Fluor 568 fluoreszcens festékkel (piros). A sejtmagokat DAPI-val tettük láthatóvá (kék). A vékony nyíl a plazmatocitákat $(\mathrm{pl}, \rightarrow$ ), a nyílhegy az óriásplazmatocitákat (gpl, -), a vastag nyíl az önocitákat (oe, $\Rightarrow$ ), a szaggatott nyíl a granulocitákat (gr, $\cdot \rightarrow$ ) jelöli. Piros nyíllal jelöltük a megfelelő ellenanyagokkal reagáló vérsejt populációkat. $\mathbf{A}^{\prime}, \mathbf{b}^{\prime}, \mathbf{c}^{\prime}, \mathbf{d}^{\prime}, \mathbf{e}^{\prime}, \mathbf{f}^{\prime}$ Nomarski optikával készült képek. Lépték: $20 \mu \mathrm{m}$ (Zeiss Axioscope

$$
2 \text { MOT). }
$$


Kimutattuk, hogy a lárvákban a morfológiai jegyek alapján egymástól nem elkülöníthető kerek sejtek (L5-1, Negri és mtsai., 2014) közel 20\%-a (6. ábra, a, vékony nyíl, pl), valamint a lárvális stádiumra jellemző nagy kiterült sejtek (L5-2, Negri és mtsai., 2014) (6. ábra, a, nyílhegy, gpl) fejezik ki a plazmatocita markereket. A kifejlett egyedekben magasabb a plazmatocita-marker pozitív sejtek aránya, mint a lárvákban: a vérsejtek megközelítőleg $80 \%$-át alkotó kis kerek és ovális sejteken nyilvánul meg a plazmatocita marker (6. ábra, b, vékony nyíl, pl). Az önocita markerek mind a lárva, mind az adult melanizáló, önocitáin mutathatók ki (6. ábra, c, d, vastag nyíl, oe). A granulocitákon és önocitákon egyaránt kifejeződő markerek a lárvák minden vérsejtjén azonosíthatók (6. ábra, e), míg a kifejlett egyedekben a marker expressziója a granulocitákra (6. ábra, szaggatott nyíl, gr) és önocitákra (6. ábra, f) korlátozódik, a kifejlett egyedekben plazmatocitákon nem mutatható ki. A 6. ábrán a 4E1 plazmatocita(6. ábra, a, b), 2.28 önocita- (6. ábra, c, d) és 4.70 granulocita-önocita (6. ábra, e, f) markerek kifejeződését mutatják be.

A plazmatocita markerek alkalmasak arra, hogy a morfológiai jegyeikben hasonló kerek lárvális vérsejteket elkülönítsék egymástól, a lárvális plazmatociták kijelölésével. Emellett a lárvákban a kerek sejtek morfológiájától eltérő nagy kiterült sejtek is expresszálják a plazmatocita markereket, ami a két vérsejttípus közös eredetére utalhat.

A plazmatocita és a granulocita-önocita markerek esetében a vérsejtek markerexpressziós mintázatában különbséget mutattunk ki a fejlődés során, amiből a vérsejt populációk arányának változására következtettünk, ezért azt részletesen megvizsgáltuk 1. (L1), 3. (L3) és 5. (L5). stádiumú lárvákban, frissen kikelt (FA) és idős adultokban (IA). A vérsejt alpopulációk arányának változását a 4E1 plazmatocitákra specifikus ellenanyag alkalmazásával indirekt immunhisztokémiai vizsgálattal határoztuk meg. Az önocita sejteket melanizációs aktivitásuk alapján különítettük el, a plazmatocitákra specifikus ellenanyaggal nem festődő és melanizációt sem mutató vérsejteket granulocitaként definiáltuk (7. ábra). Az L1 lárvákban a 4E1 markert kifejező vérsejtek aránya 12\%, L3 stádiumban 14\%, L5 stádiumban 23\%, frissen kikelt dolgozókban 77\%, idős dolgozókban 51\%. A melanizáció miatt barna színű önociták a fejlődés vizsgált szakaszaiban a vérsejtek 1\%-át tették ki. A granulociták aránya az L1 stádiumban 87\%, L3 stádiumban 85\%, L5 stádiumban 76\%, frissen kikelt dolgozókban $22 \%$, idős dogozókban 48\%. Eredményeink szerint az egyedfejlődés során a kifejlett adult stádiumig a plazmatociták aránya folyamatosan emelkedik, majd az idősebb állatokban 
lecsökken, azaz az általunk azonosított markerek alkalmasak a vérsejt alpopulációk egyedfejlődés során bekövetkező változásainak a nyomon követésére.

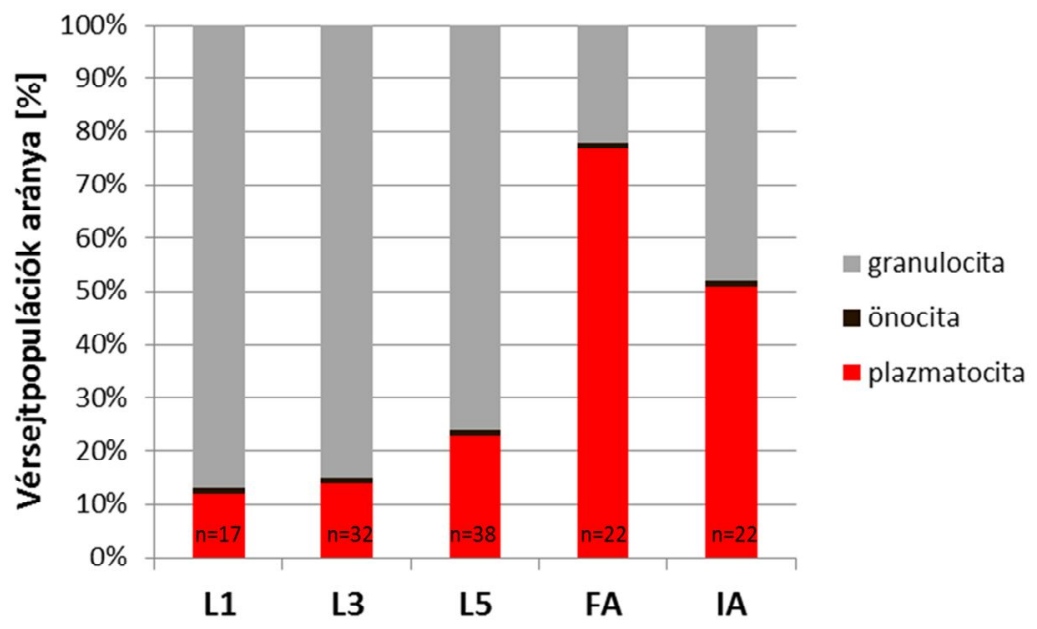

7. ábra A vérsejt populációk arányának változása az egyedfejlődés során.( n: egyedszám)

\section{IV.2 Kifejlett dolgozó középbél- és lárvális kutikula szövetek vizsgálata}

Miután dolgozó kaszt lárváiban és kifejlett egyedeiben meghatároztuk a különböző vérsejt populációkat, azt is megvizsgáltuk, hogy a vérsejtek kijelölésével azonosítható-e a mézelő méhben a D. melanogaster központi nyirokszervéhez hasonló vérsejtképző kompartmentum.

Ehhez először megvizsgáltuk, hogy az ellenanyagok kizárólag a vérsejtekkel vagy egyéb szövetekkel is reagálnak-e. Kifejlett dolgozók középbél szakaszán és lárvális kutikula szöveteken végeztünk immunhisztokémiai és immunfluoreszcens festéseket (8. ábra). A 4E1, 5A2, 6B3 plazmatocita-, a 4.19, 3B6 önocita- és 4.78 granulocita-önocita markerek nem mutattak expressziót középbél és lárvális kutikula szöveteken, csak a szövetekre tapadt vérsejteken (8. ábra, a - 4E1 markerrel bemutatva). A 2.28 (8. ábra, b) és 4.70 markerek (8. ábra, c) a középbélen és a lárva kutikuláján is kifejeződtek. A 2.28 marker esetében azt tapasztaltuk, hogy izomszerü struktúra reagált az ellenanyaggal. Ezeket a vizsgálatokat elvégeztük az 1. táblázatban bemutatott pánhemocita ellenanyagokkal is és a 4.70 ellenanyaghoz hasonló eredményeket kaptunk. A pánhemocita markerek is reagáltak a kifejlett egyedek középbél szöveteivel és a lárvák kutikula szöveteivel (nincs bemutatva). A 8. ábrán az adultokban végzett kísérleteket mutatjuk be, lárvális kutikula szövetek vizsgálatával is hasonló eredményeket kaptunk, amelyeket itt nem mutatunk be. Negatív kontrollként T2/48 humán leukocita antigénnel reagáló indifferens ellenanyagot használtunk (8. ábra, d), amely nem reagált a kifejlett egyedek középbél szövetével és a lárvák kutikula szöveteivel és a szövetekre kitapadt vérsejtekkel sem. 

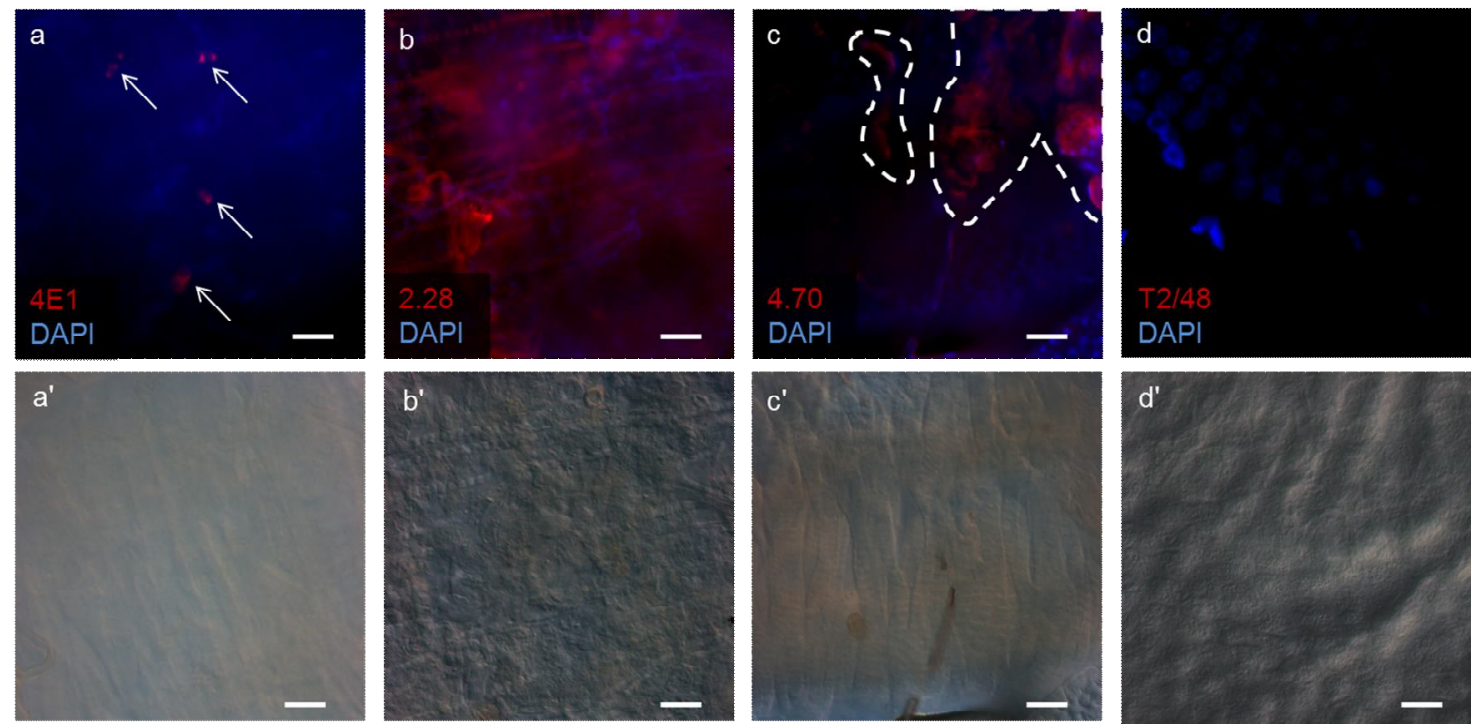

8. ábra Az ellenanyagok reakciója kifejlett dolgozó középbél szövetein. Az acetonnal fixált középbél szöveteket 4E1, 2.28 és 4.70 mAb-okkal és anti-egér Alexa Fluor 568 konjugált ellenanyaggal (piros) jelöltük. A 4E1 plazmatocita marker nem fejeződik ki a középbélen, azonban jelen van a bélfalra kitapadt vérsejteken (nyíl) (a) (piros). A 2.28 önocita marker izomszerü struktúrán fejeződik ki a középbél szöveten

(b), valamint a 4.70 marker is kifejeződik a bélfalon (szaggatott vonal) (c). Negatív kontrollként T2/48 humán leukocita antigénnel reagáló indifferens ellenanyagot használtunk (d). A sejtmagokat DAPI-val tettük láthatóvá (kék). A', b', c', d' Nomarski optikával készült képek. Lépték:20 $\mu \mathrm{m}$ (Zeiss Axioscope 2 MOT).

A szöveteken elvégzett kísérletek eredményei alapján a minden vérsejttípust kijelölő pánhemocita ellenanyagok helyett a 4E1 plazmatocitákra specifikus, a vizsgált szövetekkel nem reagáló ellenanyagot választottuk ki, mivel a pánhemocita ellenanyagok a vérsejtek mellett szövetekkel is reagáltak, ezért nehezen lett volna elkülöníthető a vérképző szövetre utaló vérsejt felhalmozódás. A szívcsövet és környezetét különös figyelemmel vizsgáltuk, ugyanis több rovarfajban is a szívcső környezetében azonosítottak vérsejtképző kompartmentumokat. Vizsgálataink során a lárvák ventrális oldalát felnyitottuk, az emésztőcsövet eltávolítva a szívcső jól láthatóvá vált. Ezután az egyedek szöveteit kipreparálva minucia tükkel rögzítve paraformaldehiddel fixáltuk. Bár a 4E1 ellenanyaggal végzett immunfluoreszcens festést követően a szívcsőben (9. ábra, szaggatott vonal) keringő vérsejtek, valamint a kutikulára kitapadt vérsejtek láthatóvá váltak (9. ábra, a), de azoknak az ecetmuslicáéhoz hasonló kompakt szervbe tömörülését nem tapasztaltuk.
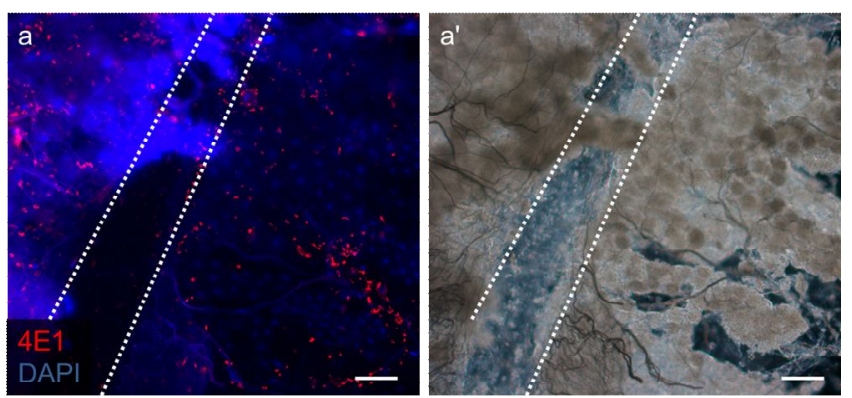

9. ábra A méh lárvális szívcsöve. A lárvális szövetek immunfluoreszcens festödése a 4E1 ellenanyaggal és anti-egér Alexa Fluor 568 festékkel (piros) jelölve, a szívcső a szaggatott vonalon belül helyezkedik el. A sejtmagokat DAPI-val tettük láthatóvá (kék) (a). A' Nomarski optikával készült kép. Lépték: $100 \mu \mathrm{m}$ (Zeiss Axioscope 2 MOT). 


\section{IV.3 A különböző kasztok vérsejttípusainak összehasonlítása molekuláris markerekkel}

A mézelő méh dolgozó kaszt vérsejt alpopulációinak jellemzése után a másik két kaszt a méhanyák és a herék kifejlett egyedeiből származó vérsejteket is megvizsgáltuk a 4E1 (10. ábra, a, b), 2.28 (10. ábra, c, d) és 4.70 (10. ábra, e, f) ellenanyagokkal. Schmid és mtsai. korábban kimutatták, hogy az egyedfejlödés során egyes kasztok között különbség van a vérsejtszám csökkenésének a dinamikájában (Schmid és mtsai., 2008), azonban a vérsejttípusok arányáról nincsenek publikált eredmények. Eredményeink szerint a méhanyákból és a herékből származó vérsejtek alpopulációi a dolgozókból származó vérsejtekkel azonos markerexpressziós mintázatot mutatnak. A plazmatocita markerek a méhanyák és a herék vérsejtjeinek megközelítőleg $80 \%$-án fejeződtek ki, az önocita markerek a melanizált vérsejteken, míg a granulocita-önocita markerek a granulocitákon és az önocitákon nyilvánultak meg, tehát nincs különbség a három kasztban azonosított vérsejttípusok arányában, ami arra utal, hogy a sejt-közvetítette immunválasz folyamatai alapvetően hasonlóképpen mehetnek végbe.
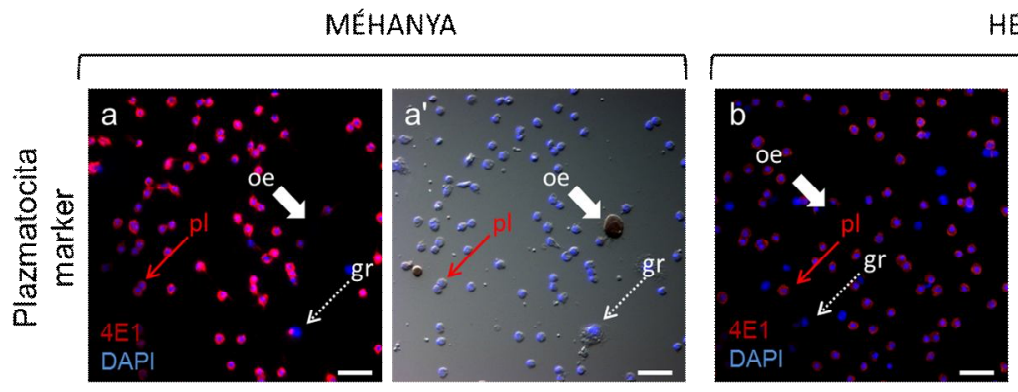

HERE
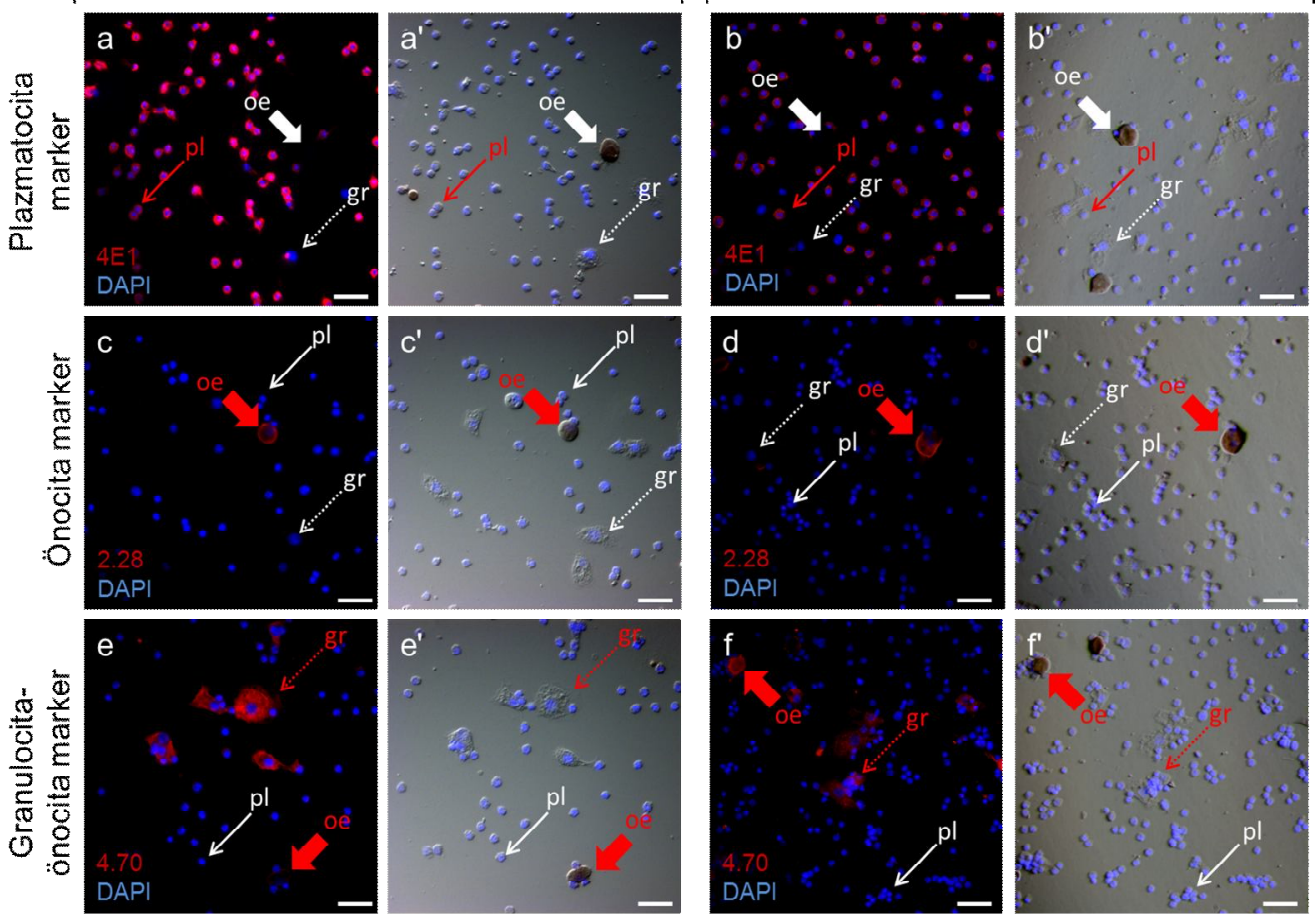

10. ábra A 4E1 plazmatocita, 2.28 önocita és 4.70 granulocita-önocita markerek kifejeződése a méhanyák és a herék vérsejtjein. A 4E1 plazmatocita (a, b), 2.28 önocita (c, d) és 4.70 granulocita-önocita

(e, f) monoklonális ellenanyagokkal és anti-egér Alexa Fluor 568 konjugált ellenanyaggal (piros) jelölt vérsejtek. A vékony nyíl a plazmatocitákat $(\mathrm{pl}, \rightarrow$ ), a vastag nyíl az önocitákat (oe, $\Rightarrow$ ), a szaggatott nyíl a granulocitákat (gr, $\cdots$ ) jelöli. Piros nyíllal jelöltük a megfelelö ellenanyagokkal reagáló vérsejt populációkat.

$\mathbf{A}^{\prime}, \mathbf{b}^{\prime}, \mathbf{c}^{\prime}, \mathbf{d}^{\prime}, \mathbf{e}^{\prime}, \mathbf{f}^{\prime}$ Nomarski optikával készült képek. Lépték: $20 \mu \mathrm{m}$ (Zeiss Axioscope 2 MOT). 


\section{IV.4 A mézelő méhben azonosított markerek kifejeződésének vizsgálata Drosophila melanogaster és Bombyx mori vérsejteken}

Megvizsgáltuk, hogy az általunk előállított ellenanyagok alkalmasak a mézelő méh vérsejtjeinek vizsgálatára mind a különböző fejlödési stádiumokban, mind pedig a különbözö kasztokban, azonban nem tudtuk, hogy használhatók-e egyéb, részletesebben vizsgált rovarfajban $D$. melanogaster-ben és $B$. mori-ban vérsejt alpopulációk elkülönítésére. A 4E1, 5A2, 6B3 plazmatocita-, a 2.28, 4.19, 3B6 önocita-, a 4.70, 4.78 granulocita-önocita markereket felismerő ellenanyagok felhasználásával végzett indirekt immunhisztokémiai és immunfluoreszcens festések azt mutatták, hogy a mézelő méhben azonosított plazmatocita specifikus markerek (11. ábra, a) sem D. melanogaster sem B. mori vérsejteken nem fejeződnek ki (11 ábra, b, c). A mézelő méh önocitáin kifejeződő markerek (11. ábra, d) azonban megnyilvánulnak a D. melanogaster kristálysejtekben, és a lamellociták egy alpopulációjában (11. ábra, e), ezen kívül a selyemhernyó önocitoidokon, granulocitákon és a plazmatociták egy részén is kimutathatók (11. ábra, f). A mézelő méh granulocitáival és önocitáival reagáló ellenanyagok mind az ecetmuslicában, mind a selyemhernyóban minden vérsejtet kijelöltek (11. ábra, g-i). Amennyiben a vizsgált ellenanyagok funkciójukban egymáshoz hasonló vérsejt populációkat jelölnek ki a különböző fajokban, a markerek alkalmasak lehetnek a rovarokban konzervált sejtközvetítette immunfolyamatok összehasonlító vizsgálatára. A 11. ábrán a 4E1 plazmatocita- (11. ábra, a-c), 2.28 önocita- (11. ábra, d-f) és 4.70 granulocita-önocita (11. ábra, g-i) markerek kifejeződését mutatjuk be, a pozitív reakciót adó vérsejt populációkat piros nyilakkal, a negatívat fehér nyilakkal jelöltük. 

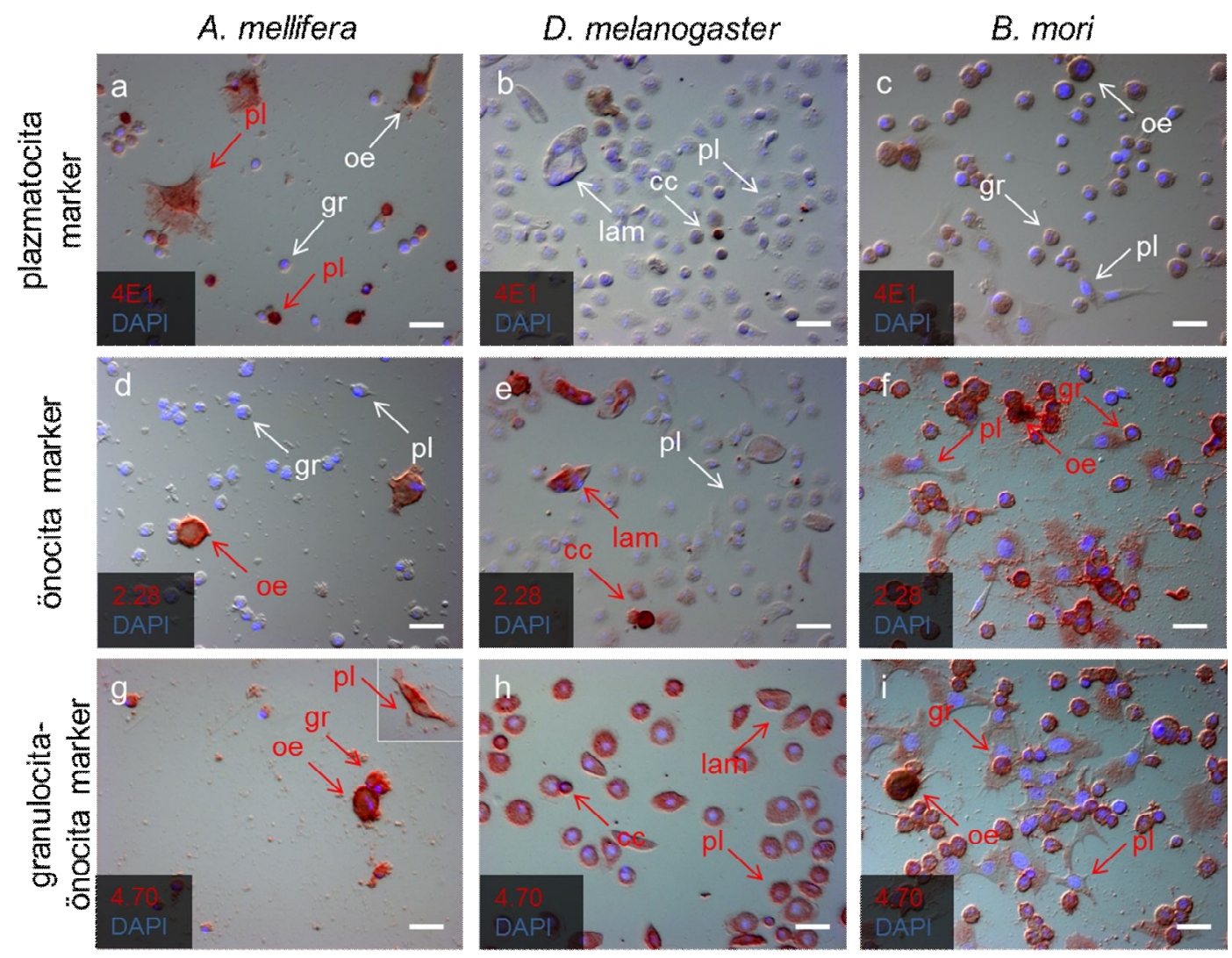

11. ábra A 4E1 (a-c), 2.28 (d-f) és 4.70 (g-i) markerek kifejeződése $A$. mellifera, D. melanogaster és B. mori lárvák vérsejtjein. A vérsejtek immunhisztokémiai reakciója $4 \mathrm{E} 1,2.28$ és 4.70 anti-egér HRPO/AEC festést követően (piros). A sejtmagokat DAPI-val tettük láthatóvá. A pozitív reakciót adó vérsejt populációkat piros nyilakkal, a negatívat fehér nyilakkal jelöltük. Pl: plazmatocita, gr: granulocita, oe: önocita/önocitoid, cc: kristálysejt, lam: lamellocita. Lépték: $20 \mu \mathrm{m}$ (Zeiss Axioscope 2 MOT).

\section{IV.5 A mézelő méh vérsejtek citoplazmájában kifejeződő markerek áramlási citometriás vizsgálata}

A mézelő méh vérsejtjeinek áramlási citometriával történő vizsgálata (deGraaf és mtsai., 2002, Hystad és mtsai., 2017, Marringa és mtsai., 2014) vérsejt alpopulációkon specifikusan megnyilvánuló molekuláris markerek hiányában eddig nem eredményezte a vérsejttípusok egyértelmü meghatározását. Az általunk azonosított molekuláris markerekről kimutattuk, hogy alkalmasak a különbözö egyedfejlödési stádiumokban és az egyes kasztokban a vérsejtek nyomon követésére immunhisztokémiai és immunfluoreszcens módszerek alkalmazásával. Megvizsgáltuk, hogy az általunk azonosított molekuláris markerek alkalmasak-e a vérsejt alpopulációk vizsgálatára a vérsejtek indirekt immunfluoreszcens festését követő áramlási citometriai analízisével.

Az áramlási citometriás analízist natív vérsejtek immunfluoreszcens festésével terveztük, azonban az eddigi kísérleteket acetonnal fixált lemezeken végeztük, ezért megvizsgáltuk a 4E1, 5A2, 6B3 plazmatocita-, a 2.28, 4.19, 3B6 önocita-, a 4.70, 4.78 
granulocita-önocita vérsejt populációkra jellemző és kontrollként a 3.35 minden vérsejtet kijelölő pánhemocita markerek kifejeződését natív vérsejteken. Az eredményeket először mikroszkópos vizsgálatok során értékeltük ki. A vérsejt populációkra jellemző markerek nem expresszálódtak a natív sejtek membránján, amiből azt a következtetést vontuk le, hogy a markerek, a 3.35 molekula kivételével, nem a vérsejtek plazmamembránjában fejeződnek ki. A 3.35 marker megtalálható a plazmamemembránban is, a kísérlet során kifejeződött a vérsejteken, tehát a reakció megfelelően ment végbe (12. ábra, d). A 12. ábrán a 4E1 plazmatocita- (12. ábra, a), 2.28 önocita- (12. ábra, b) 4.70 granulocitaönocita (12. ábra, c) és 3.35 pánhemocita (12. ábra, d) markerek kifejeződését mutatjuk be.
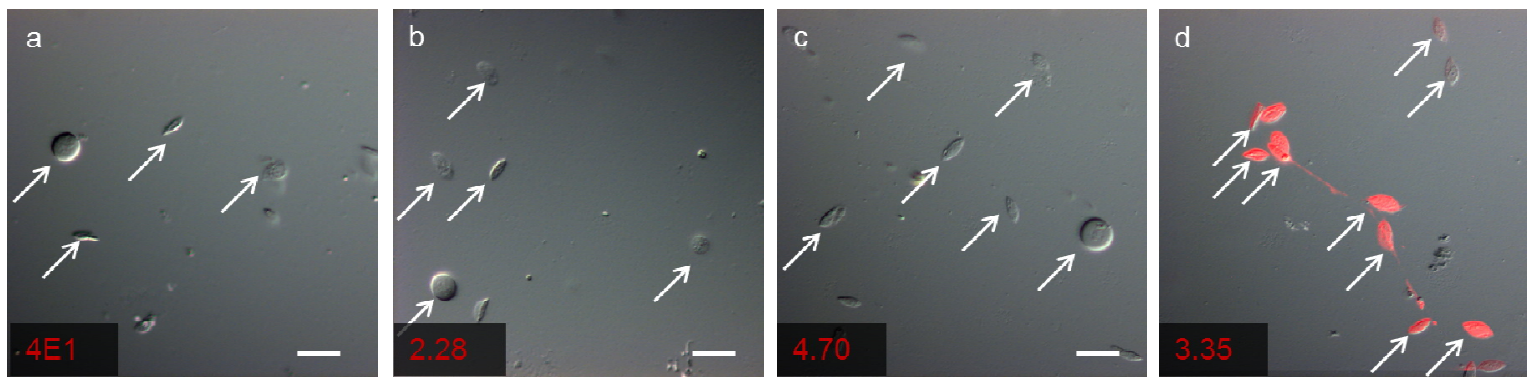

12. ábra A markermolekulák vérsejten belüli lokalizációja. A 4E1 plazmatocita (a), 2.28 önocita (b) 4.70 granulocita-önocita (c) és 3.35 pánhemocita (d) monoklonális ellenanyagokkal és anti-egér Alexa Fluor 568 fluoreszcens festékkel (piros) jelölt vérsejtek. A nyilak a vérsejtekre mutatnak. Lépték: $20 \mu \mathrm{m}$ (Zeiss Axioscope 2 MOT).

Mivel a 4E1, 5A2, 6B3 plazmatocita-, a 2.28, 4.19, 3B6 önocita-, a 4.70, 4.78 granulocita-önocita markerek nem a sejtmembránon lokalizálódnak, a vérsejteket permeabilizáltuk, hogy az ellenanyagok hozzáférhessenek a citoplazmás antigénjükhöz. A permeabilizálást követően indirekt immunfluoreszcenciát végeztünk, majd a vérsejteket áramlási citometriával analizáltuk. A kifejlett dolgozó egyedek vérsejtjeinek áramlási citometriás vizsgálata során a 4E1 (13. ábra, piros hisztogram) és a 6B3 (13. ábra, rózsaszín hisztogram) markerek az indirekt immunfluoreszcens festést követően közel azonos, magas fluoreszcencia intenzitással festődő sejtpopulációt (4E1-56\%, 6B3-58\%) jelöltek ki. A 4.70 granulocita-önocita marker (13. ábra, zöld hisztogram) a vérsejtek egy kisebb alpopulációján (18\%) expresszálódik, alacsonyabb fluoreszcencia intenzitással. Negatív kontrollként a humán leukocita közös antigént felismerő T2/48 ellenanyagot használtuk (13. ábra, fekete hisztogram).

Az áramlási citometriai analízissel kapott eredményeink megfelelnek a mikroszkópos vizsgálattal nyert indirekt immunfluoreszcencia eredményeinknek: a vérsejtek többsége pozitív a plazmatocita (6. ábra, b), míg a vérsejteknek csak körülbelül $20 \%$-a pozitív a granulocita-önocita markerekre nézve (6. ábra, f). Az ellenanyagok tehát alkalmasak a 
vérsejtek áramlási citometriás vizsgálatára, így nagyobb számú vérsejt analizálásával részletesebben nyomon tudjuk követni a vérsejt populációk változásait.

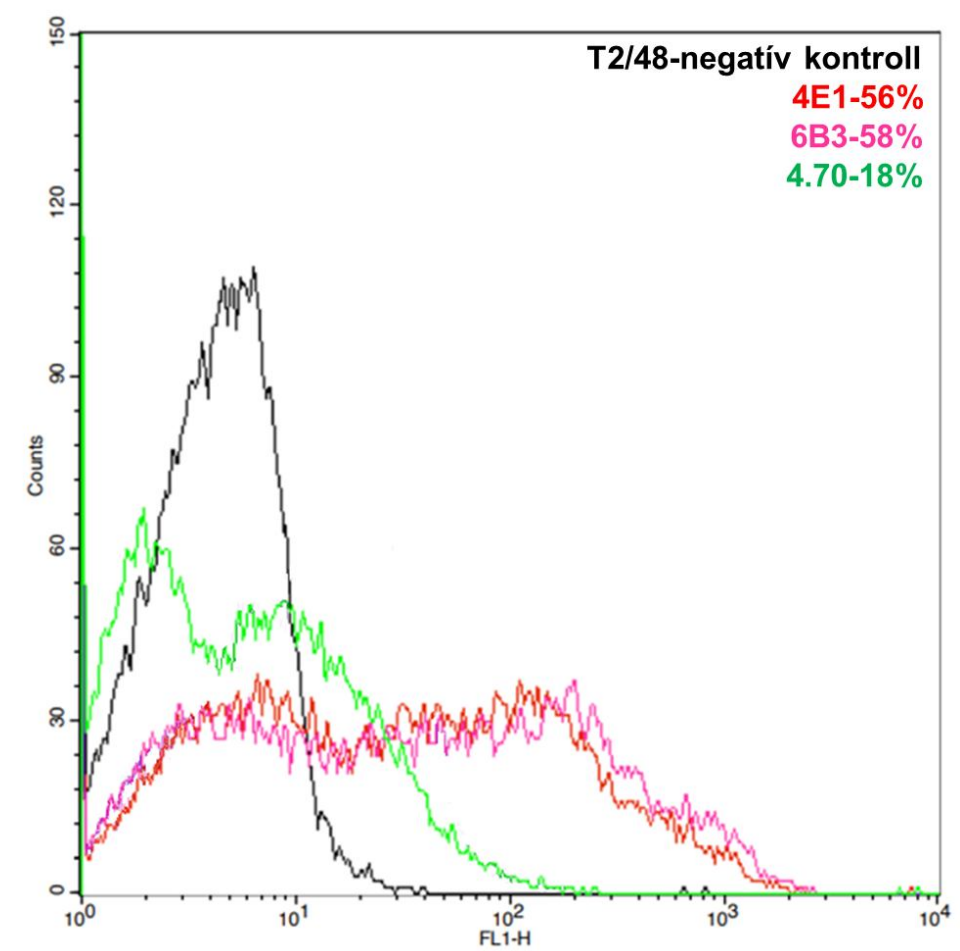

13. ábra Permeabilizált vérsejtek áramlási citometriás analízise Triton X-szel permeabilizált adult vérsejtek. A 4E1 (piros), 6B3 (rózsaszín) 4.70 (zöld) mAb és anti-egér Alexa 488 indirekt immunfluoreszcencia festését követö áramlási citometriás analizis. T2/48 negatív kontroll (fekete).

\section{IV.6 A mézelő méh vérsejt alpopulációinak funkcionális vizsgálata}

A mézelő méh vérsejtjein molekuláris markereket azonosítottunk, amelyek alkalmasak voltak a különböző vérsejt populációk elkülönítésére mindhárom kasztban és az egyedfejlődés különböző stádiumaiban mikroszkópos és áramlási citometriai vizsgálatokkal. Az így elkülönített vérsejt populációk funkciójának jellemzésére a sejtközvetítette immunválasz alapfolyamatait határoztuk meg, úgy, mint a vérsejtek fagocitáló képességét, a hemolimfa alvadékképzését és a vérsejtek testen belüli idegen részecskékhez történő kitapadását. A kísérletek során a funkcionális teszteket indirekt immunfluoreszcens és immunhisztokémiai festésekkel kombináltuk.

\section{IV.6.1 A mézelő méh vérsejtek fagocitáló képességének vizsgálata}

A sejt-közvetítette immunválasz során a vérsejtek egy része bekebelezi a mikroorganizmusokat. A mézelő méh dolgozók vérsejtjeinek a fagocitáló képességét in vivo vizsgáltuk FITC-tal jelölt E. coli, E. cloacae, S. aureus és a méhpatogén M. pluton baktériumok injektálásával. A vérsejteket az injektálás után 45 perccel távolítottuk el az állatokból perfúzióval és a sejtek fagocitáló képességét fluoreszcens mikroszkóppal 
értékeltük ki. Valamennyi baktériumfaj hasonló reakciót váltott ki, ezért a dolgozatban a FITC-tal jelölt $E$. coli baktériummal végzett vizsgálatok eredményeit mutatom be.

Megállapítottuk, hogy mind a lárvákban, mind a dolgozókban a 4E1, 5A2, 6B3 markert hordozó plazmatociták (14. ábra, a, vékony nyíl, pl) (beleértve a lárvára jellemző nagy, plazmatocita marker pozitív sejteket is) és a 2.28, 4.19, 3B6 markert hordozó önociták (14. ábra, b, vastag nyíl, oe) nem fagocitálják a fluoreszcensen jelölt baktériumokat. A 4.70, 4.78 markert hordozó vérsejtek egy része, a nem melanizálódó granulociták (14. ábra, c, szaggatott nyíl, gr) intenzív fagocitózist mutatnak. Az összes vizsgált baktériumfajt azonos mértékben fagocitálták a granulociták. A dolgozatban a kifejlett egyedekből kapott eredményeket mutatom be. Eredményeinkből megállapítható, hogy mézelő méhben a granulocita-önocita markert kifejező granulociták a fagocitáló vérsejtek, míg az önociták és a plazmatociták nem képesek a baktériumok bekebelezésére. A granulociták a vérsejtek 22\%-át teszik ki fiatal adultokban (7. ábra), ezzel szemben D. melanogaster-ben a vérsejtek több mint 95\%-a képes fagocitózisra (Rizki és Rizki., 1984). A szociális immunitással rendelkező mézelő méhek szervezetébe feltételezhetően kevesebb mikroorganizmus jut el a hemolimfáig a kiegészítő alternatív stratégiák miatt, így kevesebb fagocitáló sejtre van a szervezetnek szüksége. A 14. ábrán a 4E1 plazmatocita(14. ábra, a), 2.28 önocita- (14. ábra, b) és 4.70 granulocita-önocita (14. ábra, c) markerek kifejeződését mutatjuk be.
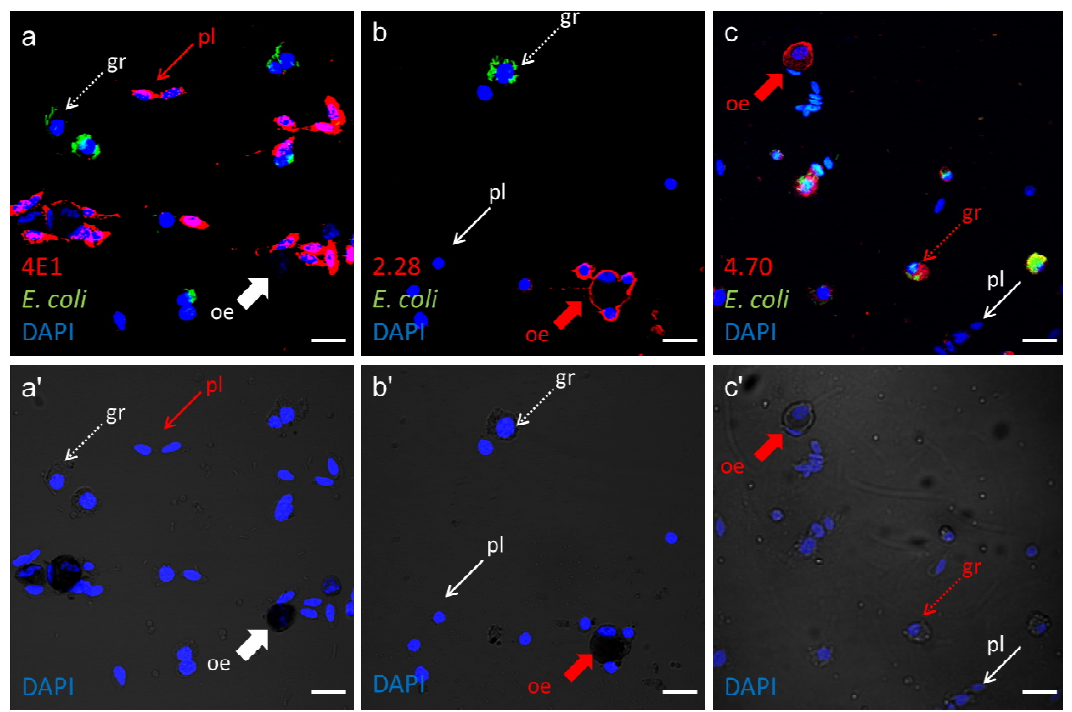

14. ábra Kifejlett dolgozók fagocita vérsejtjeinek azonosítása. A 4E1 plazmatocita (a), 2.28 önocita (b) és 4.70 granulocita-önocita (c) monoklonális ellenanyagokkal és anti-egér Alexa Fluor 568 fluoreszcens festékkel (piros) jelölt vérsejtek fagocitózisának vizsgálata FITC-tal jelölt baktériummal (zöld). A vékony nyíl a plazmatocitákat $(\mathrm{pl}, \rightarrow)$, a vastag nyíl az önocitákat $($ oe, $\Rightarrow$ ), a szaggatott nyíl a granulocitákat (gr, $\rightarrow$ ) jelöli. Piros nyíllal jelöltük a megfelelő ellenanyagokkal reagáló vérsejt populációkat. $\mathbf{A}^{\prime}, \mathbf{b}^{\prime}, \mathbf{c}^{\prime}$ a látható mezőben készült képek. Lépték: 20 m (Olympus FV1000 Confocal LSM). 


\section{IV.6.2 A hemolimfa alvadék vizsgálata}

Mechanikai sérülést követően a sérülés helyén alvadék képződik, amely meggátolja a hemolimfa vesztést és elzárja a felülfertőzés útját. A mézelö méh hemolimfájának az alvadékképzését a „függő csepp” módszerrel végeztük: a kicseppentett hemolimfát megfordítva inkubáltuk és a csepp felszínén képződött alvadékot acetonnal fixáltuk. A hemolimfa alvadékot a vérsejtekkel együtt a 4E1, 5A2, 6B3 plazmatocita-, a 2.28, 4.19, 3B6 önocita- és a 4.70, 4.78 granulocita-önocita ellenanyagokkal vizsgáltuk indirekt immunfluoreszcenciával. Megfigyeltük, hogy az anti-plazmatocita ellenanyagok a plazmatociták alkotta aggregátum mellett egy, a plazmatociták által képzett hálózatos struktúrát is kijelölnek (15. ábra, a). A granulocita-önocita ellenanyagok is reagáltak a vérsejtalvadékkal, azonban granulocitákat és önocitákat nem azonosítottunk a mintákban (15. ábra, c). Az önocita markerek nem fejeződtek ki az alvadékban (15. ábra, b). A 15. ábra $\mathrm{b}$ panelén látható, hogy az ellenanyag reagált az alvadékba véletlenszerüen kitapadt önocitával (nyíl), ami az ellenanyag megfelelő müködését mutatja. Az eredményeink alapján arra a következtetésre jutottunk, hogy az alvadékot a plazmatociták által felépített hálózatos struktúra alakítja ki, amelyhez a granulociták által termelt faktorok is hozzájárulnak. A 15. ábrán a 4E1 plazmatocita- (15. ábra, a), 2.28 önocita- (15. ábra, b) és 4.70 granulocita-önocita (15. ábra, c) markerek kifejeződését mutatjuk be.
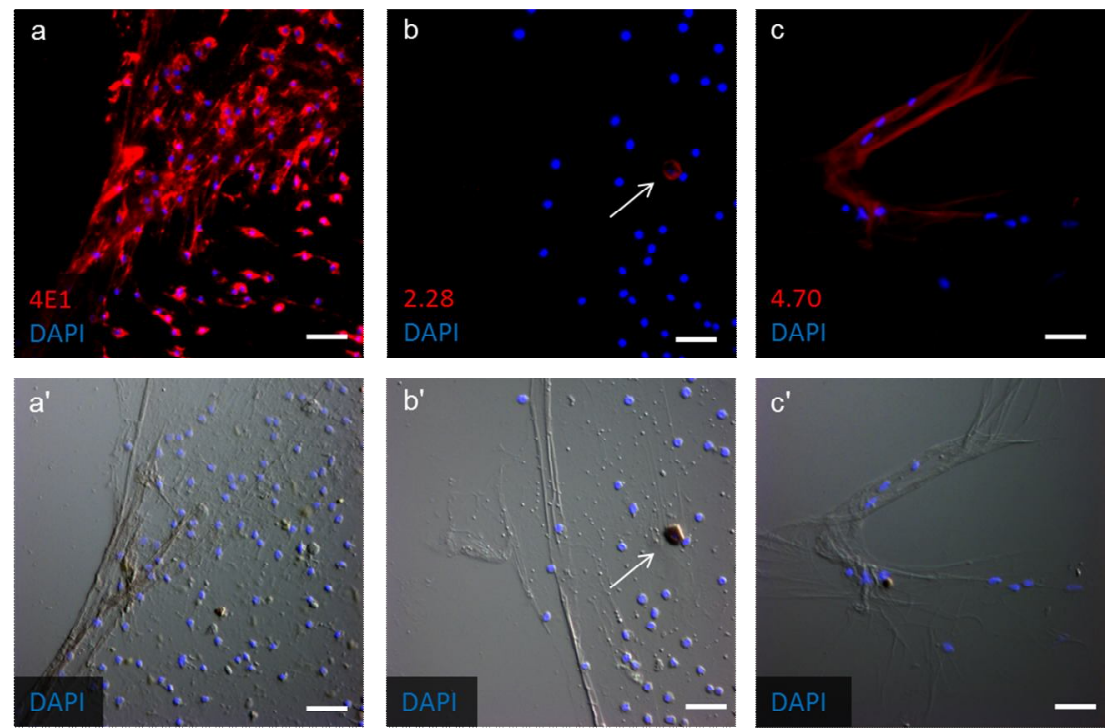

15. ábra Kifejlett dolgozók hemolimfa alvadékképzésének vizsgálata. Az alvadékot a 4E1, 2.28 és 4.70 mAb-okkal és anti-egér Alexa Fluor 568 fluoreszcens festékkel (piros) jelöltük. A sejtmagokat DAPI-val tettük láthatóvá (kék). A lemezeken képződött alvadékban a plazmatocita- (a) és a granulocita-önocita (c) markerek expresszálódnak, az önocita markerek nem, az önocita ellenanyag reagált a mintán található önocitával (b) (nyíl). A', b', c' Nomarski optikával készült képek. Lépték: 20 mm (Zeiss Axioscope 2 MOT). 


\section{IV.6.3 A testidegen részecske elhatárolásának vizsgálata}

Drosophila fajokban a testidegen részecskék, pl.: parazita peték elhatárolása a tokképző reakció (enkapszuláció) eredményeként történik, amelynek során egy új vérsejttípus differenciálódik többrétegü tokot képezve a kórokozó körül (Nappi és mtsai., 2004). Méhekben csupán néhány olyan faj ismert, amely ellen szükség lehetne hasonló védekezési folyamatra, azonban ilyen fertőzések esetén még nem vizsgálták a sejtközvetítette immunválaszt (Core és mtsai., 2012, Dutto és Ferrazzi, 2014, Menail és mtsai., 2016).

A gazdaszervezetbe kerülő idegen testek elhatárolásának modellezéséhez egy $0,08 \mathrm{~mm}$ átmérőjű damil szálat füztünk át a méhek potrohán. Három óra múlva a potroh feltárásával eltávolítottuk a testidegen részecskét (damil szálat), tárgylemezre fixáltuk, majd a damil szálra tapadt alvadékot indirekt immunfluoreszcens festéssel vizsgáltuk a 4E1, 5A2, 6B3 plazmatocita-, a 2.28, 4.19, 3B6 önocita- és a 4.70, 4.78 granulocitaönocita markerek alkalmazásával.

Kísérleteink során azt tapasztaltuk, hogy a plazmatociták hálózatos struktúrát alkotva kitapadtak az idegen testre (16. ábra, a), a hálózatos struktúrában a melanizált sejtekre jellemző önocita markereket is megfigyeltük (16. ábra, b), míg a granulocita-önocita markerek (16. ábra, c) kifejeződését nem tapasztaltuk. A plazmatociták képesek arra, hogy hálózatos sejt aggregátumot létrehozva elhatárolják az idegen testeket, a sejt aggregátum feltehetőleg az önociták által termelt faktorokat is tartalmazza, amire az önocita markerek homogén expressziója utal. Nem mutattuk ki, hogy D. melanogaster tokképzéséhez hasonlóan új effektor vérsejttípus differenciálódna, valamint kevés olyan ismert kórokozója van a méheknek, amely ellen aktív enkapszulációs immunválaszra van szükség, így azt feltételezzük, hogy a plazmatociták által képzett sejtréteg a sejtek egymáshoz történő aggregálódása miatt alakul ki, nem aktív tokképző folyamat. A 16. ábrán a 4E1 plazmatocita- (16. ábra, a), 2.28 önocita- (16. ábra, b) és 4.70 granulocitaönocita (16. ábra, c) markerek kifejeződését mutatjuk be. 

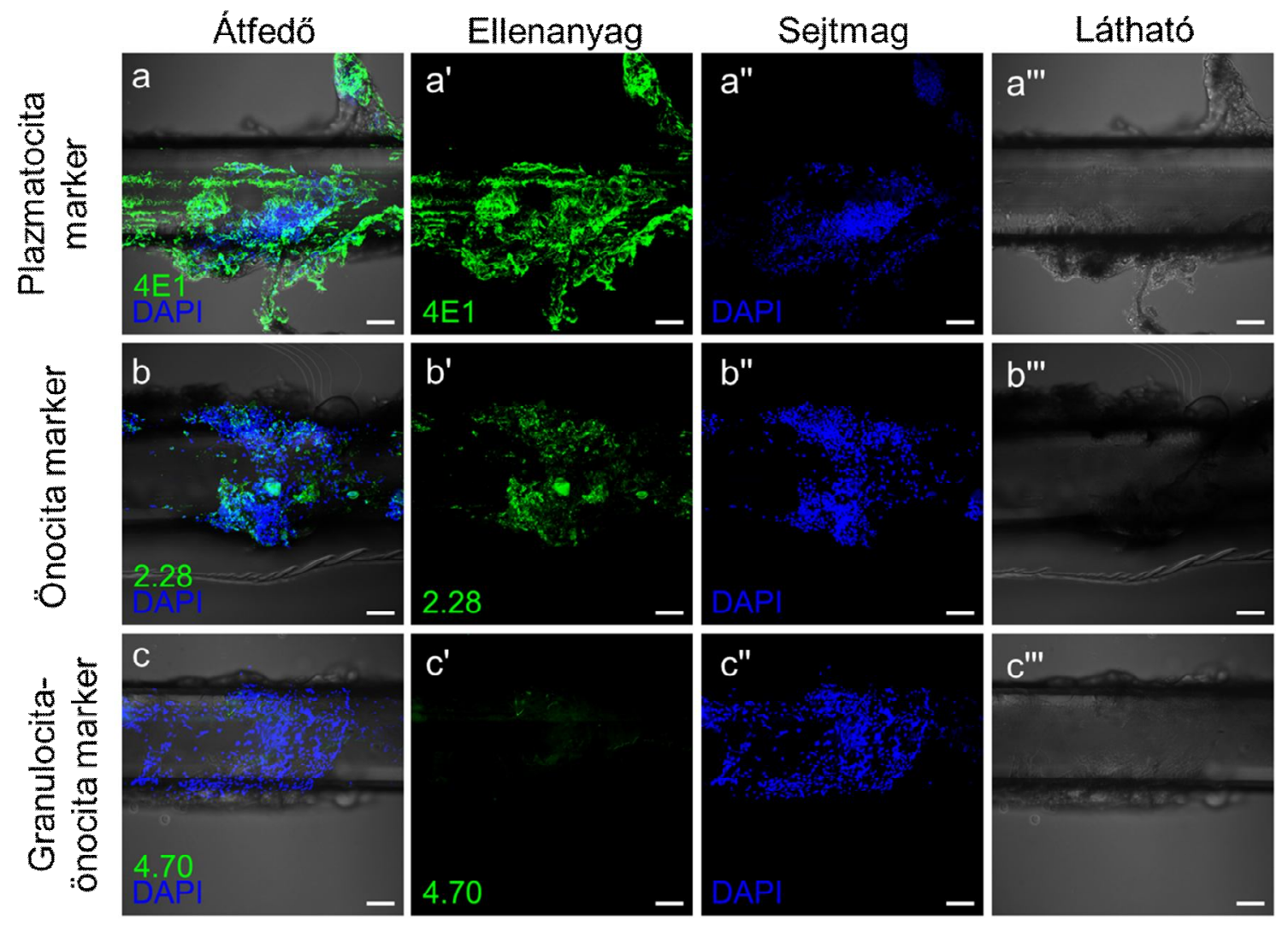

16. ábra Az idegen testhez kitapadó vérsejtek vizsgálata. A damil szál körüli sejt aggregátumot a 4E1 (a), 2.28 (b), és

4.70 (c) mAb-okkal és anti-egér Alexa Fluor 488 másodlagos ellenanyaggal (zöld) (a', $\left.\mathbf{b}^{\prime}, \mathbf{c}^{\prime}\right)$ jelöltük. A sejtmagokat DAPI-val tettük láthatóvá (kék) (a", b", c"). A"', b"', $\mathbf{c}^{\prime \prime " ~ l a ́ t h a t o ́ ~ m e z o ̋ b e n ~ k e ́ s z u ̈ l t ~ k e ́ p e k . ~ L e ́ p t e ́ k: ~} 20$ um (Olympus FV1000 Confocal LSM).

\section{IV.6.4 Vajk fehérjék vizsgálata mézelő méhben}

A vérsejtek funkcionális vizsgálata során megállapítottuk, hogy a kizárólag egyedi immunválasszal rendelkező D. melanogaster fajhoz képest a mézelő méhben kevesebb vérsejt fagocitál (22\%), immunindukciót követően nem differenciálódnak új vérsejttípusok, feltételezhetően a sejt-közvetítette immunválasz aktiválódása előtt egyéb, alternatív védekezési mechanizmusok mehetnek végbe. Az első, a mechanikai védelmi vonal is feltehetően kiemelt szerepet játszik, a védekezésben, ezért a mézelő méhben is megkíséreltük a Drosophila-ban általunk azonosított kutikulához kapcsolt fehérjék kimutatását.

A csoportunkban azonosított $D$. melanogaster Nimród génklaszter és a vajk géneket is magában foglaló Nim kromoszóma régió - amelynek fehérjéiről kimutatták, hogy a fagocitózisban játszanak szerepet - homológjai mézelő méhben is megtalálhatók (Kurucz és mtsai., 2007a, Somogyi és mtsai., 2008, Somogyi és mtsai., 2010, Zsámboki és mtsai., 2013). Kimutattuk, hogy a vajk génekről átíródó fehérjék a $D$. melanogaster kutikulájában fejeződnek ki. A vajk gének által kódolt Vajk1 és Vajk4 fehérjék Drosophila-ban az embrió és a késői báb stádiumokban mutathatók ki Western blot eljárással, valamint 
indirekt immunfluoreszcencia festéssel is detektálhatók az embrió tracheában, a nyálmirigy csatornában és a hasi oldalsó horogsorokban. Késői báb stádiumban a Vajk1 fehérje a tracheákban, a Vajk4 fehérje pedig a szörszálak tövében fejeződik ki (Cinege és mtsai., 2017). Mivel a Vajk géncsalád több tagjával homológiát mutató gén a mézelő méh genomjában is fellelhető (Somogyi és mtsai., 2010), a Vajk fehérjékre specifikus ellenanyagokkal Western blot analízissel megvizsgáltuk, a Drosophila Vajk1 és Vajk4 homológjainak kifejeződését a mézelő méhben. A Vajk1 fehérjét egyik mintában sem, a Vajk4 fehérjét azonban az atkával fertőzött és nem fertőzött késői bábokból készített mintákban sikerült kimutatnunk, amelynek kifejeződése jóval gyengébb volt, mint a Drosophila késői báb mintákban. A fehérje molekulatömege a Drosophila-ban azonosított Vajk4 fehérje molekulatömegével megegyező 38 kDa volt (17. ábra). Összehasonlítottuk a D. melanogaster fehérjeszekvenciát a mézelő méh fehérje adatbázissal, 62\%-os egyezést találtunk a feltételezhető prolin-gazdag protein 4-gyel (XP_624317.2). Indirekt immunfluoreszcens festés során nem sikerült kimutatnunk a Vajk4 fehérjét a szőrszálak tövében vagy egyéb szöveteken. Ez abból adódhat, hogy a fehérje sokkal kisebb mennyiségben van jelen a méh kutikulában, mint az ecetmuslicáéban, ami arra utal, hogy a fagocitózisban szerepet játszó géneket kódoló Nim kromoszóma régióban azonosított kutikuláris Vajk fehérjék homológjai kevésbé járulnak hozzá mézelő méhben az elsődleges védelmi vonal felépítéséhez, mint az ecetmuslicában. Azonban az is lehetséges, hogy a mézelő méh natív Vajk4 fehérje térszerkezete lényegesen eltér a Drosophila fehérje térszerkezetétől, ezért az ellenanyag nem ismeri fel a fehérjét.

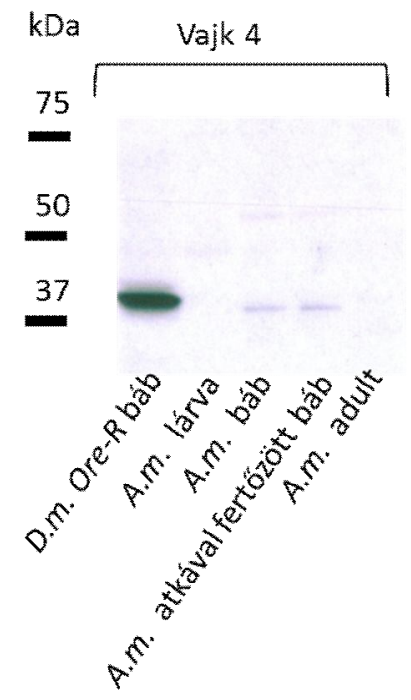

17. ábra Vajk4 fehérje kifejeződésének vizsgálata. SDS-PAGE-t követő Western blot analízise különböző stádiumú egyedeknek a Vajk 4 ellenanyag felhasználásával.

D.m. Drosophila melanogaster kontroll, A.m. Apis mellifera 


\section{IV.7 A plazmatocita, önocita és granulocita-önocita markerek molekulatömegének meghatározása}

Miután megvizsgáltuk a markerek expressziós mintázatát a vérsejt populációkon és meghatároztuk a vérsejttípusok funkcióját, meghatároztuk az ellenanyagok által felismert fehérjék molekulatömegét. A kísérletet nem redukáló körülmények között SDS-PAGE-t követő Western blot analízissel végeztük. A 4E1 (18. ábra, a) és $6 \mathrm{~B} 3$ (18.ábra, b) plazmatocita markerek molekulatömege egyaránt a körülbelül 400 kDa-os tartományba esik. A molekulatömeg és a markerexpresszió alapján feltételezzük, hogy a két ellenanyag ugyanazt a fehérjemolekulát ismeri fel (epitóp analízist nem végeztünk). A Western blot analízis során az önocita 2.28 marker (18. ábra, c) esetében körülbelül 75 kDa-nál és 150 kDa-nál detektáltunk jelet, aminek alapján feltételezzük, hogy a 150 kDa-os jel a 75 kDaos fehérje dimerizált formája. Az 5A2 plazmatocita-, 4.19, 3B6 önocita- és 4.70, 4.78 granulocita-önocita markerek molekulatömegének meghatározása nem járt eredménnyel. Elképzelhető, hogy az ellenanyag olyan konformáció-függő epitópot ismer fel, amelynek térszerkezete az SDS-PAGE minta-előkészítés során megváltozik, így az ellenanyag nem képes megfelelően kötődni.

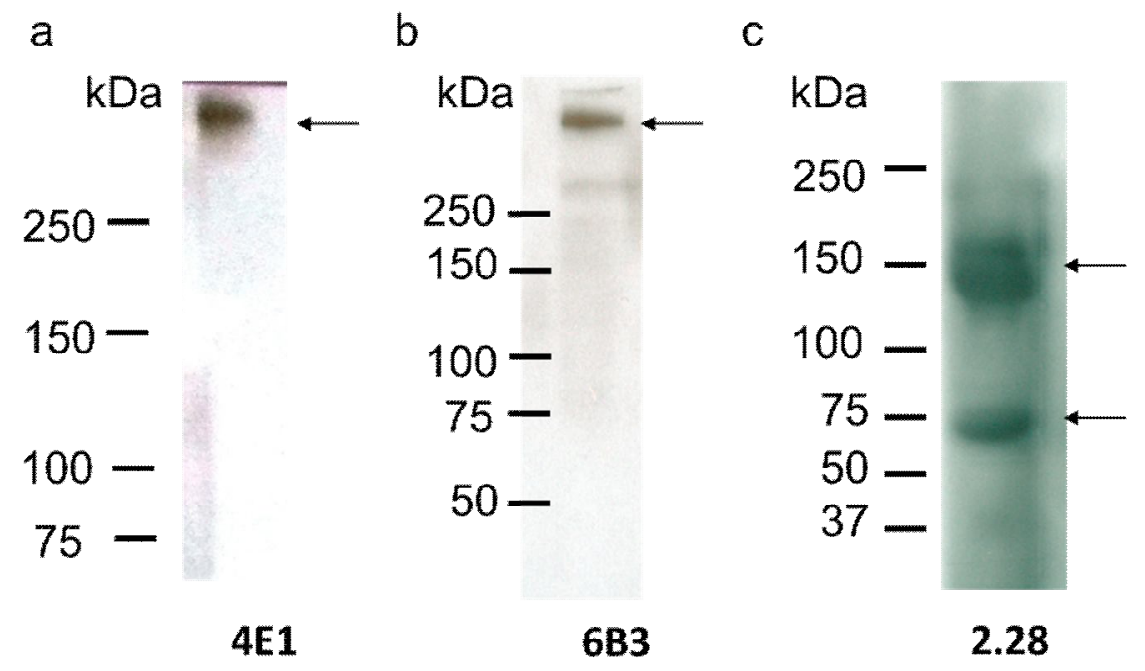

18. ábra A 4E1 (a) és 6B3 (b) plazmatocita és 2.28 önocita (c) marker molekulatömegének meghatározása. A detektált molekulatömegeket nyilakkal jelöltük. 


\section{IV.8 A mézelö méh vérsejtjein azonosított markermolekulák jellemzésének összefoglalása}

A vizsgálatok során részletesen elemeztük a 4E1, 5A2, 6B3 plazmatocita, 2.28, 4.19, 3B6 önocita és 4.70, 4.78 granulocita-önocita markereket. Az eredményeket a 2. táblázat foglalja össze. Az általunk azonosított markerek a vérsejtek citoplazmájában fejeződnek ki. A 4E1, 5A2 és 6B3 plazmatocita markerek a hemolimfa alvadékban is kimutathatók voltak, de a vérsejteken kívül a lárvális kutikula és adult középbél szöveten nem fejeződtek ki. Ezek a markerek a testüregbe juttatott idegen testhez kitapadó vérsejteken minden esetben detektálhatók voltak. A melanizációra hajlamos önocita vérsejteken megnyilvánuló 2.28, 4,19 és 3B6 markerek sem a fagocitáló sejteken, sem a hemolimfa alvadékban nem detektálhatók, a szervezetbe juttatott testidegen anyag körüli sejt aggregátumban viszont egyértelműen kimutathatók. A 4.19 és 3B6 markerek az önocitákon kívül a lárvális kutikula és adult középbél szöveten nem fejeződtek ki, a 2.28 marker viszont a kiboncolt állat izomszerű struktúrájával reagált. A 4.70 és 4.78 granulocita-önocita markerek mind a fagocitáló sejteken mind a hemolimfa alvadékon megnyilvánulnak, viszont, nem fejeződnek ki az idegen testek köré tapadt sejt aggregátumban, a 4.70 marker lárvális kutikula és adult középbél szöveten is expresszálódik. Mivel a 4E1 plazmatocita és 2.28 önocita markerek molekulatömegét is sikerült meghatároznunk a továbbiakban ezt két markert vizsgáltuk meg részletesebben.

\begin{tabular}{|c|c|c|c|c|c|c|c|c|}
\hline Név & Izotípus & Vérsejttípus & $\begin{array}{l}\text { Fagocitáló } \\
\text { sejtek }\end{array}$ & $\begin{array}{c}\text { Hemolimfa } \\
\text { alvadék }\end{array}$ & $\begin{array}{l}\text { Idegen } \\
\text { test }\end{array}$ & $\begin{array}{c}\text { Natív } \\
\text { vérsejtek }\end{array}$ & $\begin{array}{l}\text { Lárvális } \\
\text { és adult } \\
\text { szövetek }\end{array}$ & Molekulatömeg \\
\hline 4E1 & $\operatorname{IgG1K}$ & plazmatocita & negatív & pozitív & pozitív & negatív & negatív & 420 kDa \\
\hline $5 A 2$ & $\operatorname{lgG} 1 \mathrm{~K}$ & plazmatocita & negatív & pozitív & pozitív & negatív & negatív & ND \\
\hline $6 B 3$ & $\operatorname{lgG} 2 a \kappa$ & plazmatocita & negatív & pozitív & pozitív & negatív & negatív & 420 kDa \\
\hline 2.28 & $\lg \mathrm{Mk}_{\mathrm{K}}$ & önocita & negatív & negatív & pozitív & negatív & pozitív & $75 ; 150 \mathrm{kDa}$ \\
\hline 4.19 & $\lg \mathrm{MK}$ & önocita & negatív & negatív & pozitív & negatív & negatív & ND \\
\hline $3 B 6$ & $\lg$ Мк & önocita & negatív & negatív & pozitív & negatív & negatív & ND \\
\hline 4.70 & $\lg \mathrm{Mk}$ & $\begin{array}{c}\text { granulocita- } \\
\text { önocita }\end{array}$ & pozitív & pozitív & negatív & negatív & pozitív & ND \\
\hline 4.78 & $\operatorname{lgG1\kappa }$ & $\begin{array}{c}\text { granulocita- } \\
\text { önocita }\end{array}$ & pozitív & pozitív & negatív & negatív & negatív & ND \\
\hline
\end{tabular}

2. táblázat Az $A$. mellifera vérsejteken azonosított molekuláris markerek összefoglalása. ND: nem detektáltuk. 


\section{IV.9 A 2.28 önocita marker további jellemzése}

A 2.28 marker a melanizációra hajlamos önocitákon fejeződik ki. A marker nem csak az A. mellifera vérsejtek alpopulációján, de a D. melanogaster PPO-t termelő kristálysejteken és a lamellociták egy részén, valamint a selyemhernyó önocitoidokon is megnyilvánul (11. ábra, d-f). A 2.28 marker molekulatömegét Western blot analízissel határoztuk meg ( 75 és $\sim 150 \mathrm{kDa}$ ) (18. ábra, c). Zufelato és mtsi. 2004-ben azonosították méh hemolimfában az $A$ mellifera profenoloxidázt (AmPPO), majd Lourenço és munkatársai 2005-ben meghatározták az aktív enzim molekulatömegét, ami 74,4 kDa, ez megfelel a Western blot során kapott jelnek. Összehasonlítottuk a D. melanogaster PPO-ok (DmPPO) valamint az AmPPO fehérje szekvenciát CLUSTALW analízissel (http://www.genome.jp/tools/clustalw). A fehérjék 47\%-60\%-os szekvencia azonosságot mutattak. Az azonos szakaszokat a 19. ábrán piros színnel emeltem ki. Eredményeink alapján úgy véljük, hogy a 2.28 ellenanyag az AmPPO-t ismeri fel. Feltételezésünk kísérleti rendszerekben történő további vizsgálatát tervezzük.

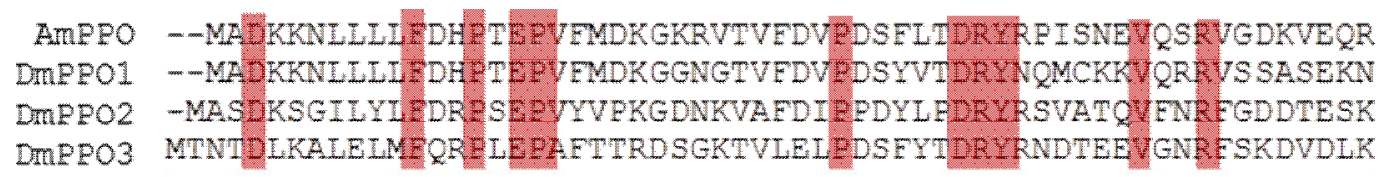

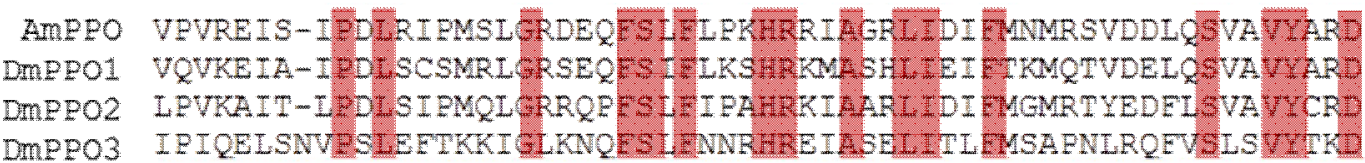

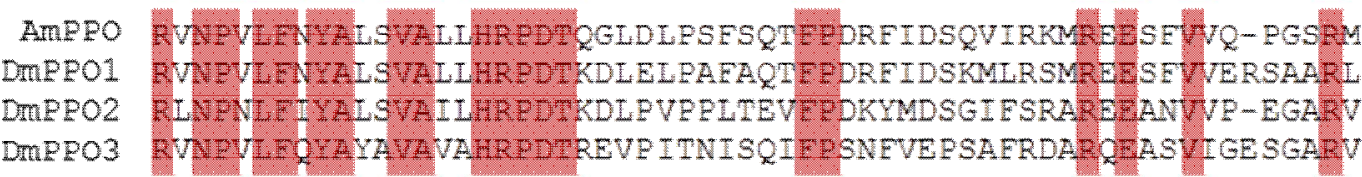

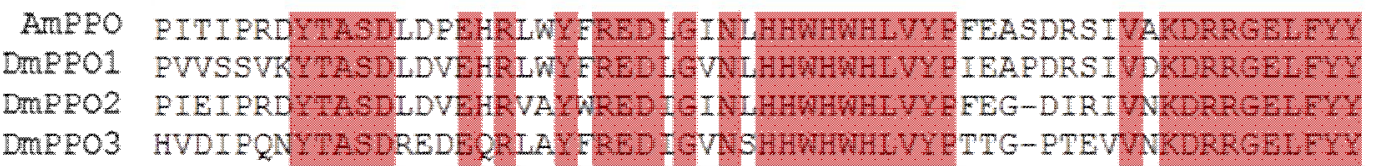

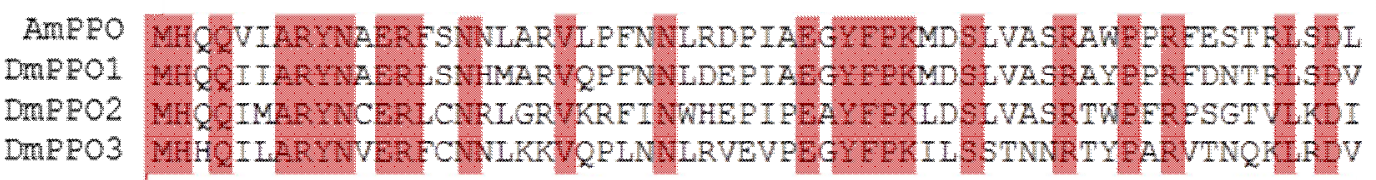

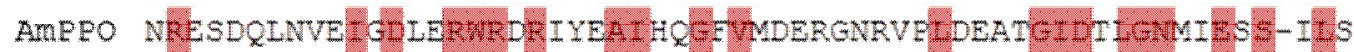
DMPPO1 DRENNQLRVGIDDMKRNRER IYEA IHCGYUDTNNEKIVLDDAKGIDILGNIIEAS-DLI DMPPO2 NRQVDELNEDIQDLERTRDRIYEA IHTGS INTRGERIQITEKNGIDVLGNIMEAS-ILS DMPPO3 DRHDG--RVEISIVERWRDHVLARIDCENVDSSGNRI PLDEVRGIDIIGMMIEASPVS 

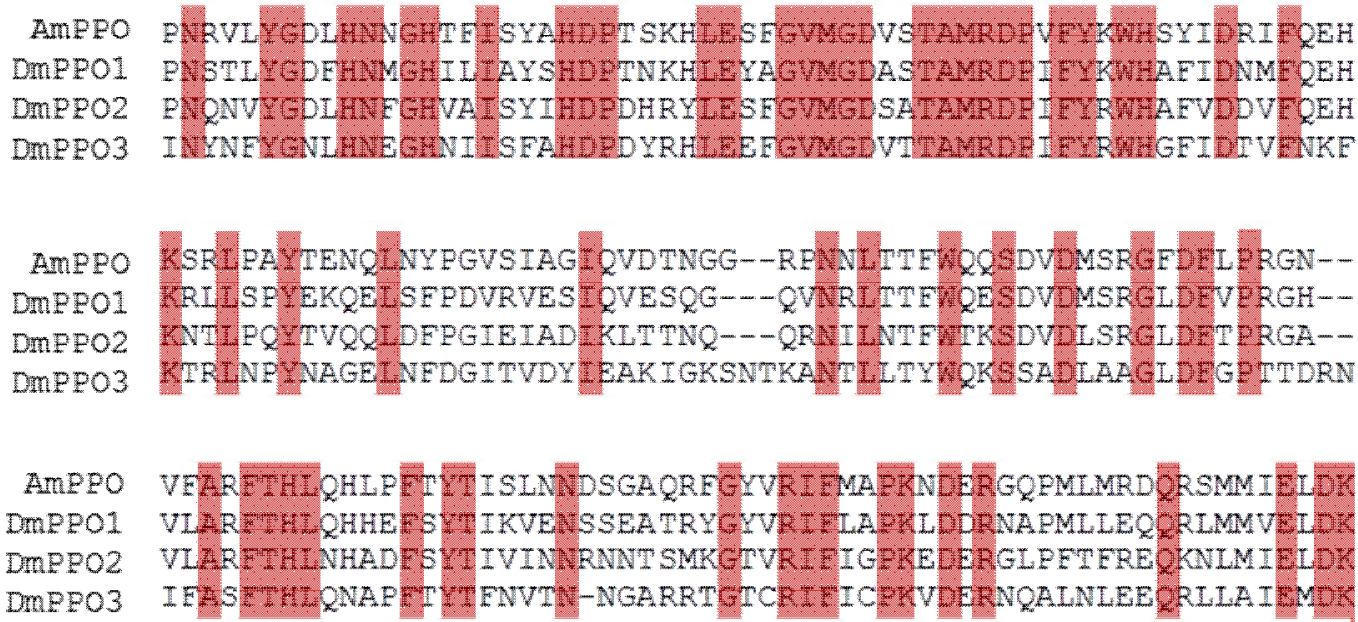

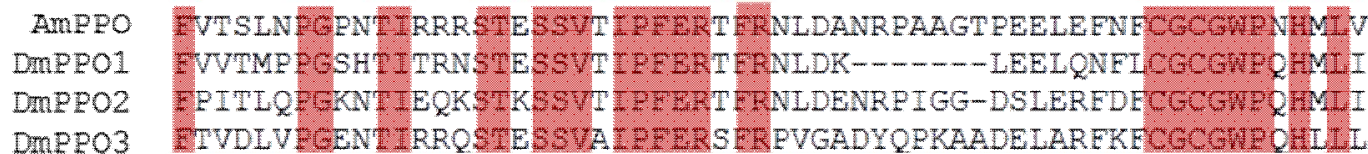

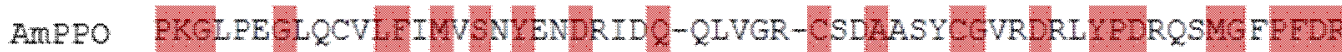
DMPPO1 DmPPO2 DMPPO3 PKGRPEORFE

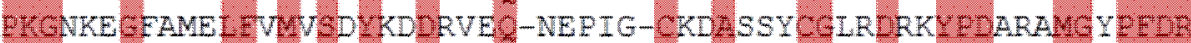
PKGNAQSMVEDIFVMISD SCDSVEOEKT PNDACSTAYS ECELKDKLYEDRRTMCY FDR

AmPPo DMPPO1

DMPPO2

DMPPO3

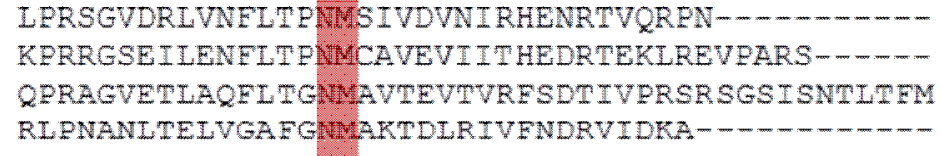

19. ábra Az AmPPO, DmPPO1, DmPPO2 és DmPPO3 fehérjeszekvenciájának összehasonlítása. Az azonos szakaszokat pirossal jelöltük.

\section{IV.10 A mézelő méh hemolektin azonosítása (AmHml)}

A 4E1 plazmatocita markert proteomikai analízis céljából immunprecipitáltuk a vérsejtekből, amelyen a Szegedi Biológiai Kutatóközpont Tömegspektometriai laboratóriuma folyadékkromatográfiával kapcsolt tandem tömegspektrometriai (LC-MS/MS) analízist végzett. Kontrollként a 4B8/F12 indifferens antitestet használtuk, amely nem reagált a mézelő méh vérsejtekkel. A vizsgálat során a Western blot jelnek megfelelő gél darabokat analizáltattuk a 4E1 plazmatociták elleni és a 4B8/F12 indifferens antitesttel kezelt mintákból. Az analízis eredményeként a 4E1 antitesttel jelölt minta $400 \mathrm{kDa}$ körüli tartományából az Uniprot adatbázisban szereplő A0A087ZSR0, 420 kDa-os fehérjét azonosítottuk, amely nem volt jelen a kontroll mintában. Az azonosított fehérje homológ a más rovarfajokban leírt hemolektin fehérjékkel (Melipona 
quadrifasciata, Uniprot ID: A0A0N0BH61; Habropoda laboriosa, Uniprot ID: A0A0L7QSW0; Camponotus floridanus, Uniprot ID: E2AVY8).

Annak megerösítésére, hogy a 4E1 markert a mézelő méh hemolektin gén $(\mathrm{AmHml})$ kódolja (Lesch és mtsai., 2007, Wallberg és mtsai., 2014), dolgozó lárvákban egy neminvazív eljárással RNS interferenciát végeztünk (Nunes és Simões 2009). Az AmHml génre specifikus dupla-szálú RNS-t (AmHml-dsRNA) szintetizáltunk, amelyet cukorszirupban feloldottunk, majd 2. stádiumú dolgozó lárvákat etettünk vele. Kontrollként GFP-dsRNSsel kezelt és kezeletlen lárvákat használtunk. Az utolsó lárvastádiumot elért egyedek vérsejtjeit a 4E1 ellenanyag felhasználásával indirekt immunfluoreszcencia analízissel vizsgáltuk (20. ábra, a-c). Eredményeink szerint az AmHml-dsRNS-sel kezelt lárvákban a 4E1 marker pozitív sejtek aránya kisebb volt (14\%), mint a kontroll (28\%) vagy a GFPdsRNS-sel kezelt $(28 \%)$ állatokban $(\mathrm{p}<0.05)$. Kísérleteink során az AmHml-dsRNS-sel kezelt állatokban a 4E1 molekula kifejeződésének csendesítése egyrészt azért nem volt teljes (20. ábra, d), mert az RNS interferenciával sosem csendesíthető el százszázalékosan a target fehérje, valamint elképzelhető, hogy a vérsejtek egy része már az RNSi kezelés előtti állapotban is $4 \mathrm{E} 1$ marker pozitív volt.
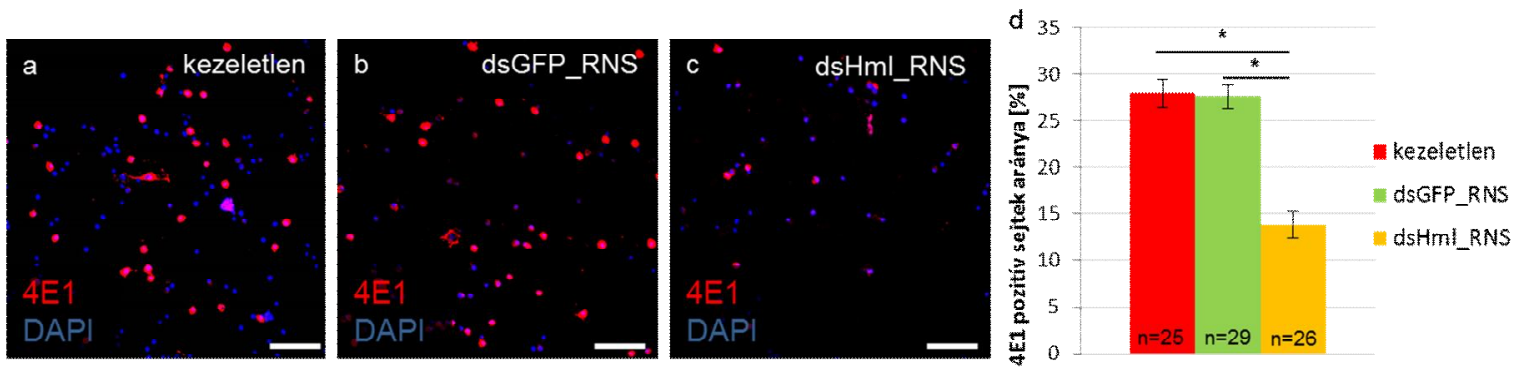

20. ábra. ábra A mézelő méh hemolektin azonosítása és RNS interferenciával történő csendesítése. Dupla-szálú RNSi (AmHml-dsRNA) kezelt, (c), GFP-dsRNS-kezelt (b) és kezeletlen állatok (a) vérsejtjeinek indirek immunfluoreszcencia analízise 4E1 ellenanyag és anti-egér Alexa 568 másodlagos ellenanyag felhasználásával. A sejtmagokat DAPI-val jelöltük (kék). Lépték: 50 m (Olympus FV1000

Confocal LSM). A 4E1 pozitív vérsejtek kvantitatív analízise (n: egyedszám) (d). Az eredményeket egyszempontos varianciaanalízissel értékeltük ki, amit Tukey post hoc elemzés követett $(\mathrm{p}<0,05)$.

\section{IV.11 A plazmatocita vérsejt populáció vizsgálata vegyszereknek kitett és vegyszerrel kezelt méhcsaládok egyedeiben}

Miután sikerült azonosítanunk a mézelő méh hemolektint, a fehérjére specifikus 4E1 ellenanyagot indirekt immunfluoreszcens módszerrel a gyakorlatban is felhasználtuk. Kísérleteink során vegyszereknek kitett és vegyszerrel kezelt kifejlett dolgozók vérsejtjeit analizáltuk a 4E1 ellenanyaggal és meghatároztuk a plazmatocita alpopuláció arányának változását a vérképben. A dolgozókat egyedenként vizsgáltuk az atkairtásra használt 
amitráz kezelés előtt és után, valamint meghatároztuk a neonikotinoid csávázószerrel kezelt vetőmagról kifejlődött méhlegelön tartott méhek és normál méhlegelőn tartott méhcsaládok egyedeiben a plazmatociták arányának változását.

\title{
IV.11.1 Neonikotinoiddal csávázott vetőmagból fejlődő méhlegelő
}

\begin{abstract}
Korábban kimutatták, hogy neonikotinoid kezelés hatására csökken a vérsejtek száma, a melanizációs aktivitás és a hemolimfa antimikrobiális aktivitása mind a dolgozókban, mind a méhanyákban (Brandt és mtsai., 2016, 2017).
\end{abstract} Megvizsgáltuk, hogy terepen végzett körülmények között

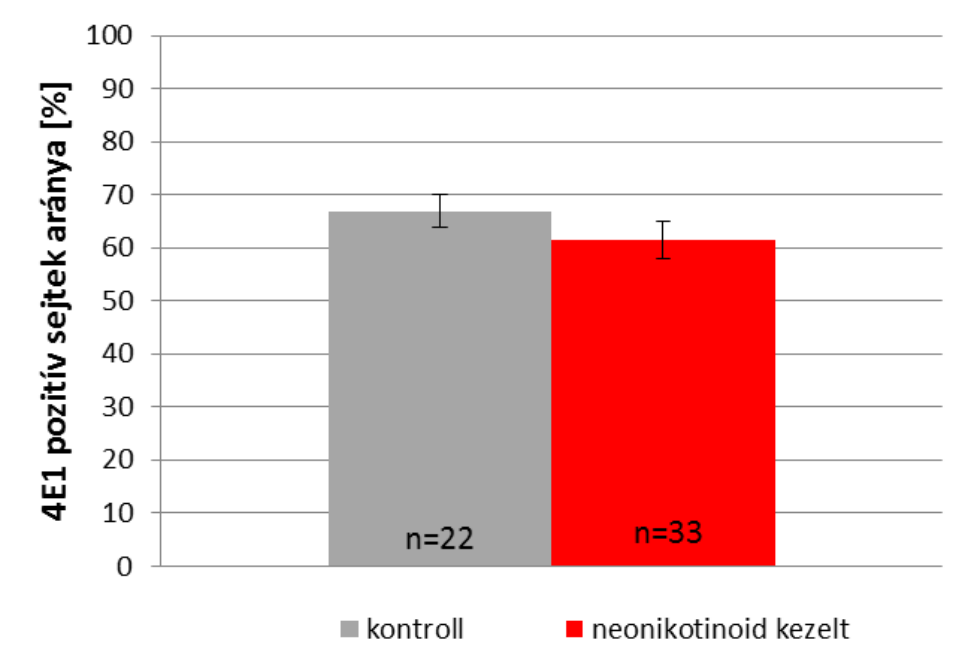

21. ábra A plazmatociták aránya kontroll és neonikotinoiddal csávázott méhlegelőn tartott méhekben (n: egyedszám).

észlelhető-e változás a vérsejt populációk arányában. Kísérleteinkhez olyan méhcsaládokat választottunk ki, amelyek neonikotinoiddal (tiometoxam) csávázott napraforgómagból fejlődött növényekről gyüjtöttek. Kontrollként csávázatlan napraforgómagból származó növények alkotta méhlegelőn tartott méhcsaládok egyedeit is megvizsgáltuk. A kontroll méhlegelő olyan távolságra helyezkedett el neonikotinoiddal csávázott vetőmaggal bevetett területektől, hogy a méhek azt nem érhették el. Eredményeink szerint a kontroll, csávázatlan napraforgó legelön tartott méhcsaládok egyedeinek hemolimfájából izolált vérsejtek 67\%-ban tartalmaztak 4E1 markermolekulát hordozó plazmatocitákat. A neonikotinoiddal kezelt vetőmagból származó méhlegelőn tartott család egyedeinek vizsgálata során 61\%-os plazmatocita arányt kaptunk, ami azt mutatja, hogy napraforgó vetőmag neonikotinoiddal történt kezelése szignifikánsan $(p>0,05)$ nem befolyásolja a plazmatociták arányát mézelő méhben (21. ábra). Ebből arra következtethetünk, hogy az irodalomban kimutatott vérsejtszám csökkenés (Brandt és mtsai., 2016, 2017). során a plazmatociták aránya nem változik. Az is lehetséges, hogy a terepen végzett kísérletek során a növényen át felszívódó és a méhek emésztőrendszerén keresztül a szervezetbe kerülő vegyszer nincs hatással a sejt-közvetítette immunválaszra a laboratóriumban, kísérleti körülmények közt elvégzett kezelésekhez képest. 


\section{IV.11.2 Amitráz kezelés}

A méhészetekben az atkafertőzés amitráz tartalmú szerekkel mérsékelhető. A vegyszert többnyire ködöléssel juttatják a kaptárba, amely során a méhek is közvetlenül érintkeznek a szerrel, így az a laboratóriumban végzett neonikotinoiddal történő kezeléshez hasonlóan (Brandt és mtsai., 2016, 2017) hatással lehet, a sejt-közvetítette immunfolyamatokra.

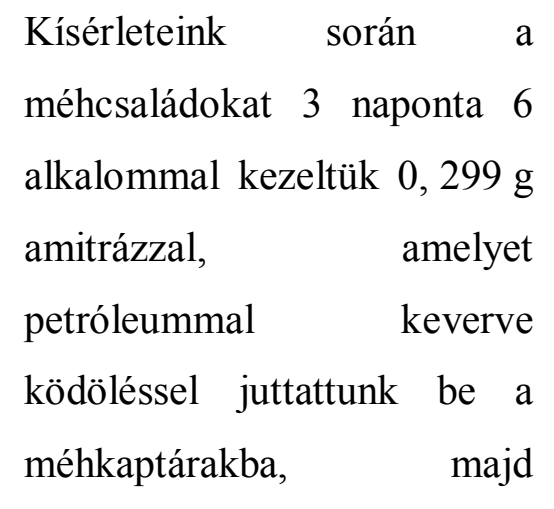
megvizsgáltuk a kezelés előtt és a kezelés után a családok egyedeinek

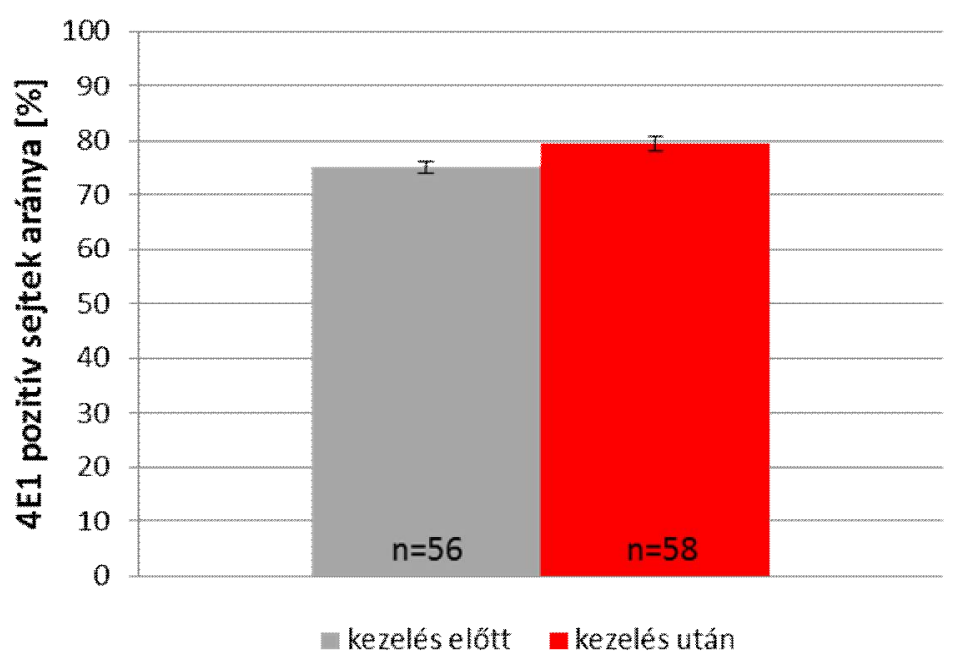

22. ábra A plazmatociták aránya amitrázkezelés előtt és után. (n: egyedszám)

vérsejtösszetételét. A 4E1 molekula indirekt immunfluoreszcencia festése alapján megállapítottuk, hogy az amitráz kezelés előtt (75\%) és után (79\%) nem volt szignifikáns különbség a plazmatociták arányában $(\mathrm{p}>0,01)$ (22. ábra). Nem tudtunk kimutatni a plazmatociták arányában változást a közvetlenül a méhek szervezetével érintkező vegyszeres kezelés során, hasonlóan a közvetve a növényen keresztül felszívódó vegyszeres kezeléshez (lsd.:IV.11.1. Neonikotinoiddal csávázott vetőmagból fejlődő méhlegelö). Ebből arra következtetünk, hogy a vegyszeres kezelés nem váltja ki a plazmatociták arányának kóros változását. 


\section{IV.12 Varroa szenzitív higiénikus képességű (VSH) méhcsaládok vizsgálata}

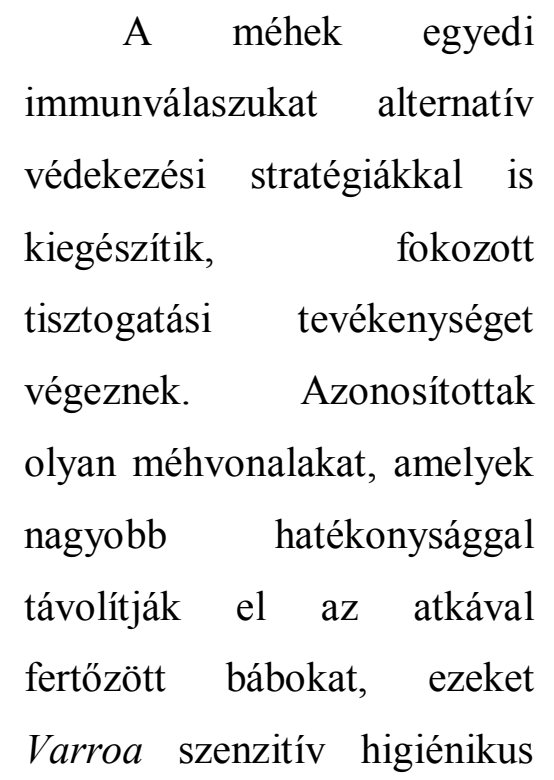

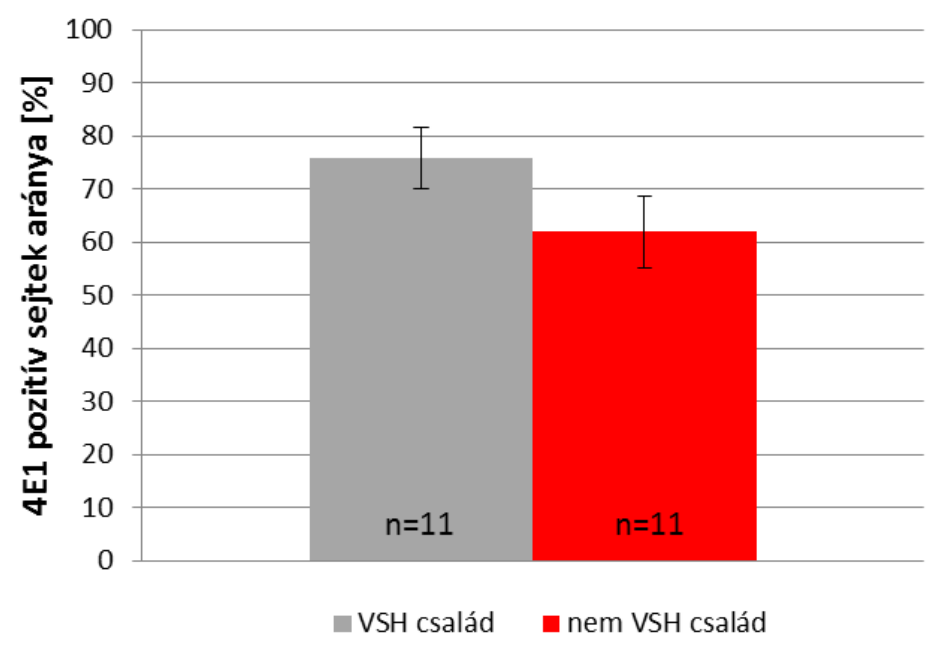

23. ábra A plazmatociták aránya VSH és nem VSH méhcsaládban. (n: egyedszám)

képességü (VSH) méheknek nevezzük. Kísérleteink során összehasonlítottuk egy jól tisztogató méhcsalád és egy gyenge higiénikus képességű méhcsalád között a plazmatociták arányát, annak vizsgálatára, hogy az alternatív védekezés mennyire egészíti ki, a sejt-közvetítette immunitást: indukál-e változást a sejt-közvetítette immunitás effektor sejtjeiben, ha egy méhcsaládnak rosszabb a higiénikus viselkedése. Nem volt szignifikáns különbség ( $>00,05)$ a VSH (76\%) és a nem VSH (62\%) méhcsaládoknál (23. ábra) a plazmatociták arányában, a higiénikus viselkedés hatékonysága nem volt összefüggésben a plazmatocita vérsejt populáció arányával.

\section{IV.13 Atkafertőzött méhcsalád egyedeinek vizsgálata}

A $V$. destructor atka külső parazitaként a bábok, és a kifejlett egyedek testnedveivel táplálkozik nyílt sebet ejtve a kutikulán. A sebgyógyulás során alvadék képződik. Kimutattuk, hogy az alvadékképzésért a 4E1 ellenanyag pozitív plazmatociták a felelősek. A kísérletek során egyazon méhcsaládból származó atkával szúrt és szúratlan (kontroll), lárvák és adultok keringő vérsejtjeit vizsgáltuk a 4E1 plazmatocitákra specifikus ellenanyag felhasználásával indirekt immunfluoreszcens festéssel egyedenként. Megvizsgáltuk, hogy befolyásolja-e a fertőzés a hemolektint kifejező plazmatociták arányát a hemolimfában és az alvadékképzést. A kísérletek során kikelés előtti adultokat vizsgáltunk, amelyek biztosan fertőzöttek voltak, amikor elérték a báb stádiumot, azaz nem az adult stádiumban fertőződtek meg. Eredményeink szerint a fertőzött lárvákban 17\%, a nem fertőzött kontroll lárvákban 13\%, míg a fertőzött adultokban $60 \%$, a nem fertőzött 
adultokban $\quad 75 \%$ volt $\quad$ a plazmatociták aránya. A kontroll és az atkafertőzött egyedek vizsgálata során a plazmatociták arányában nem találtunk szignifikáns különbséget $\quad(p>0,05)$ ábra).

Az atkával- és steril tűvel szúrt bábok kutikuláján immunhisztokémiai festéssel megvizsgáltuk a szúrás környezetét. A seb környéke mind az atkával (25. ábra),

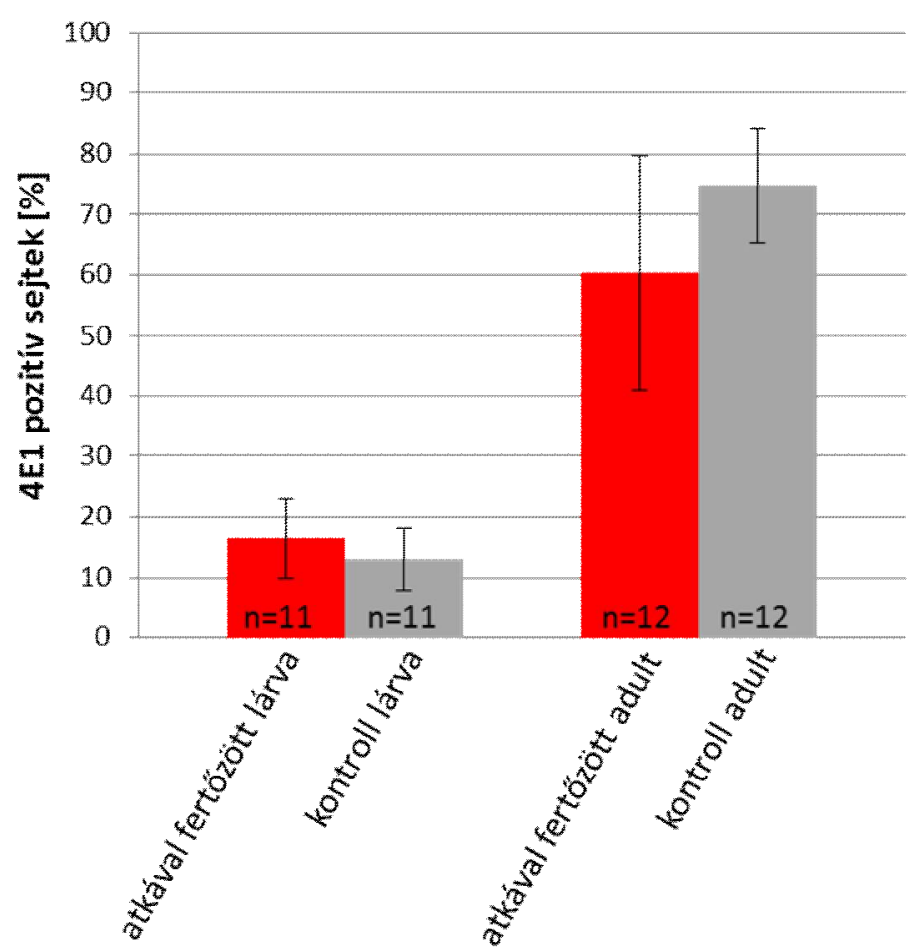

24. ábra A plazmatociták aránya atkaszúrt és nem atkaszúrt lárvákban és kikelés előtti adultokban. (n: egyedszám) mind a steril tüvel történő szúrást (nem mutatjuk be) követően melanizálódott, a sérülés közelében vérsejtekből álló aggregátumot nem találtunk, a kutikula falára szétszórtan kitapadt vérsejtek mind az atkafertőzött, mind a kontroll állatokban hasonló számban és sürüségben voltak jelen.

Mivel nem tudtunk kimutatni vérsejtalvadékot a szúrás helyén és az atkafertőzés nem befolyásolta az alvadékképző sejtek arányát sem, így azt feltételezzük, hasonlóan a fagocitózis és tokképzés esetében tapasztaltakhoz, hogy a sebgyógyulás során is háttérbe szorul a vérsejtek szerepe, mivel az egyedek steril, zárt helyen fejlődnek a lépsejtekben, ami miatt alacsony a valószínűsége, hogy sérülés éri azokat a fejlődés során.
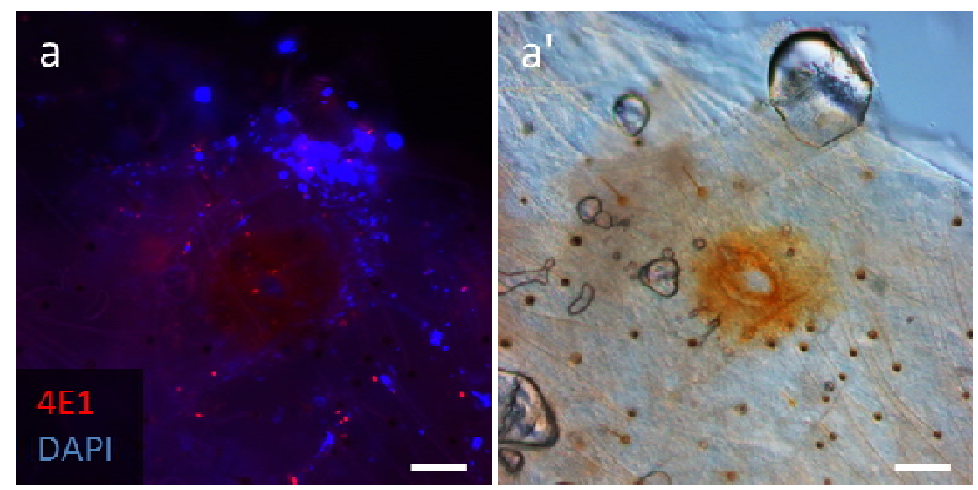

25. ábra Atkaszúrás vizsgálata báb kutikulán. Az atkával szúrt kutikula darabhoz tapadt plazmatocitákat 4E1 ellenanyaggal és anti-egér Alexa Fluor 568 fluoreszcens festékkel (piros) jelöltük. A sejtmagokat DAPI-val tettük láthatóvá (kék) (a). Az atkaszúrás körül a szövetek melanizálódtak (a'). Lépték: $100 \mu \mathrm{m}$ (Zeiss Axioscope 2 MOT) 


\section{Az eredmények megbeszélése}

A rovarok, kórokozókkal szembeni védekezésében, a fizikai védekezés mellett, alapvető szerepet játszik az immunitás. A szociális rovarokra jellemző alternatív védekezést és az egyedi immunitás humorális komponenseit korábban már részletesen tanulmányozták, azonban a sejt-közvetítette immunválaszról szerzet ismereteink nem elég alaposak és egyértelműek. Egyéb Hymenoptera fajokhoz hasonlóan (Amaral és mtsai., 2010, Manfredini és mtsai., 2008) a mézelő méh vérsejtjei, alaktani jellemzőik alapján nagymértékben különböznek egymástól (deGraaf és mtsai., 2002, El-Mohandes és mtsai., 2010, Marringa és mtsai., 2014, Negri és mtsai., 2014, Richardson és mtsai., 2018, Van Steenkiste, 1988). Azonban a morfológiai, hisztokémiai és lektin jelöléssel végzett eredmények nem konkluzívak, ezért nem használhatóak fel a vérsejtek részletesebb vizsgálatára. Szükségessé vált egy olyan módszer és eszköztár létrehozása, amely a funkciójukban különböző vérsejttípusokat megbízhatóan képes elkülöníteni egymástól (deGraaf és mtsai., 2002, Negri és mtsai., 2016).

A sejt-közvetítette immunválasz vizsgálatára, a Drosophila fajokban sikeresnek bizonyult stratégiát (Kurucz és mtsai., 2007b, Márkus és mtsai., 2015) követve, ellenanyagokat állítottunk elő, amelyek segítségével specifikus markereket azonosítottunk a vérsejttípusok pontos azonosítására. Az ellenanyagokat a vérsejteken adott reakciómintázatuk alapján klaszterekbe soroltuk, segítségükkel három fó vérsejttípust azonosítottunk: a plazmatocitákat, az önocitákat és a granulocitákat. A 3. táblázat tartalmazza a különböző módszerekkel azonosított vérsejttípusok összehasonlítását.

$\mathrm{Az}$ általunk plazmatocitaként azonosított vérsejt populáció morfológiai jegyek alapján megfeleltethető, az elektronmikroszkópos és fluoreszcensen jelölt lektinekkel végzett mikroszkópos és áramlási citometriás vizsgálatok során plazmatocitaként, vagy W-2-4 sejtekként definiált vérsejtekkel. Lárvákban a Negri és munkatársai (2014) által azonosított L5-1 kerek morfológiájú vérsejt populációról kimutattuk, hogy az két alpopulációra bontható: a sejtek egy része kifejezi a plazmatocita markereket, amelyből feltételezhetően a kifejlett egyedek plazmatocitái származnak. Emellett a plazmatocita markerek a lárvális L5-2 nagy kiterült óriássejteken is kifejeződtek, amelyről kimutatták, hogy a sejtek aggregálódásában van szerepük. A funkciójuk hasonló a kifejlett egyedek plazmatocitáihoz, amelyek képesek sejt aggregátumot vonni a testüregbe helyezett damil szálra, hogy elhatárolja azt (Gábor és mtsai., 2017), akárcsak a D. melanogaster lamellocitái a parazita darázspete köré (Rizki és Rizki., 1984). A Zaprionus indianus 
fajban a nematociták, D. ananassae fajban pedig a sokmagvú óriássejtek (Kacsoh és mtsai., 2014, Márkus és mtsai., 2015) rendelkeznek hasonló funkcióval. Az idegen testek elhatárolása során nem differenciálódnak speciális vérsejttípusok, mint Drosophila fajokban a lamellociták, vagy az óriássejtek (Kacsoh és mtsai., 20014, Márkus és mtsai., 2015, Rizki és Rizki, 1992), az idegen testet elhatároló plazmatociták immunindukció nélkül is jelen vannak a keringésben. Ennek az lehet a magyarázata, hogy a mézelő méhnek feltehetően nincs olyan endoparazitája, amely speciálisan differenciálódó tokképző sejtek képződését váltaná ki; eddig csak néhány olyan parazitát azonosítottak, amelyek a méhek testüregében fejlődnek (Core és mtsai., 2012, Dutto és Ferrazzi, 2014, Menail és mtsai., 2016). Ennek a jelenségnek feltehetően érdekes filogenetikai vonatkozásai vannak, amelyek tanulmányozása az immunrendszer és a parazita kölcsönhatás vonatkozásában új ismeretekhez vezethet.

\begin{tabular}{|c|c|c|c|c|c|c|c|}
\hline \multirow[t]{2}{*}{ Stâdium } & VERSEJTTIIPUS & FUNKCIÓ & $\begin{array}{c}\text { Van } \\
\text { Steenkiste, } \\
1988\end{array}$ & $\begin{array}{l}\text { deGraaf } \\
\text { et al., } 2002\end{array}$ & $\begin{array}{l}\text { Marringa } \\
\text { ot al., } 2014\end{array}$ & $\begin{array}{l}\text { Negri et al., } \\
\qquad 2014\end{array}$ & $\begin{array}{c}\text { El- } \\
\text { Mohandes } \\
\text { et al, } 2010\end{array}$ \\
\hline & markerek & & EM & FACS & FACS & mikroszkóp & hisztokémia \\
\hline \multirow{6}{*}{ 寜 } & $\begin{array}{c}\text { plazmatocita } \\
(4 \mathrm{E} 1 ; 5 \mathrm{~A} 2 ; 6 \mathrm{~B} 3 \\
4.70,4.78)\end{array}$ & $\begin{array}{l}\text { - aggregáció } \\
\text { - alvadék }\end{array}$ & & & & $L 5-1$ & plazmatocita \\
\hline & $\begin{array}{c}\text { óriás plazmatocita } \\
(4 E 1 ; 4.70,4.78)\end{array}$ & $\begin{array}{l}\text { - aggregáció } \\
\text { - alvadék }\end{array}$ & & & & L5-2 & \\
\hline & granulocita $(4.70)$ & - fagocitózis & & & & L5-1 & granulocita \\
\hline & $\begin{array}{c}\text { önocita } \\
(2.28 ; 4.19 ; 386 ; \\
4.70 ; 4.78)\end{array}$ & - melanizáció & & & & & onocita \\
\hline & & & & & & & koagulocita \\
\hline & & & & & & & $\begin{array}{l}\text { binukleált } \\
\text { sejtek }\end{array}$ \\
\hline \multirow{5}{*}{ 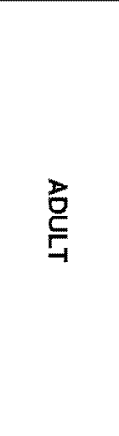 } & $\begin{array}{c}\text { plazmatocita } \\
(4 E 1 ; 5 A 2 ; 6 B 3)\end{array}$ & $\begin{array}{l}\text { - aggregáció } \\
\text { - alvadék }\end{array}$ & $\begin{array}{l}\text { plazmatocita } \\
\text { (PL1-4) }\end{array}$ & $\begin{array}{l}\text { plazmatocita } \\
\text { (PL1-4) }\end{array}$ & $\begin{array}{c}\text { Q4 } \\
\text { plazmatocita }\end{array}$ & $W-2-4$ & \\
\hline & $\begin{array}{l}\text { granulocita } \\
(4.70 ; 4.78)\end{array}$ & - fagocitózis & $\begin{array}{l}\text { granulocita } \\
\text { (GR) }\end{array}$ & $\begin{array}{l}\text { granulocita } \\
\text { (GR) }\end{array}$ & & $W_{1}$ & \\
\hline & $\begin{array}{c}\text { önocita } \\
(2.28 ; 4.19 ; 386 \\
4.70 ; 4.78)\end{array}$ & - melanizáció & $\begin{array}{c}\text { Onocita } \\
(\mathrm{OC})\end{array}$ & $\begin{array}{l}\text { onocita } \\
(0 \mathrm{C})\end{array}$ & & & \\
\hline & & & $\begin{array}{l}\text { koagulocita } \\
\text { (CG) }\end{array}$ & $\begin{array}{l}\text { koagulocita } \\
\text { (CG) }\end{array}$ & & & \\
\hline & & & & & $\begin{array}{c}\text { Q1-Q3 } \\
\text { permeabilizalt } \\
\text { sejtek }\end{array}$ & & \\
\hline
\end{tabular}

3. táblázat Különböző módszerekkel meghatározott vérsejttípusok dolgozó lárvákban és adultokban.

A plazmatocita markerek közül Western blot analízissel és tömegspektrometriai vizsgálattal kimutattuk, hogy a fehérje a mézelő méh hemolektin (AmHml). Az eredményeinket RNS interferencia (Nunes és Simões, 2009) vizsgálatokkal erősítettük meg (Gábor és mtsai., 2017). A hemolektin a véralvadás egyik fontos eleme, amelynek emlős homológja az alvadékképzésben és a vérlemezkék kitapadásában nélkülözhetetlen 
von Willebrand homológ domaineket tartalmaz (Goto és mtsai., 2003, Lesch és mtsai., 2007). A hemolektinnel homológ hemocitin gént azonosították B. mori-ban (Kotani és mtsai., 1995), valamint az A. mellifera genomban is leírtak egy hemolektin szekvenciát (Consortium, 2006, Lesch és mtsai., 2007). Az AmHml egy fontos jelölt lehet a Varroa fertőzések elleni küzdelemben, ahol a fertőzés során nyílt sebek keletkeznek az állatokon. A sebgyógyulásnak jelentős szerepe van a másodlagos fertőzések elleni védelemben. Az afrikai méhvonalak ellenállóbbak az európai vonalaknál atkafertőzésre (Martin és Medina, 2004). Kimutatták, hogy egyéb immungének mellett az AmHml génben különbség található az afrikai és az európai méhek között (Wallberg és mtsai., 2014). Összehasonlították az afrikai és európai méhpopulációk hemocita koncentrációját és a hemociták $\mathrm{AmHml}$ expresszióját atkafertőzés során, a hemocita koncentráció ugyan mindkét csoportnál megemelkedett, azonban az AmHml expressziója nem változott (Koleoglu és mtsai., 2018). $\mathrm{Az}$ atkával fertőzött egyedek vizsgálata során mi sem tapasztaltunk különbséget a hemolektin pozitív vérsejtek arányában a nem fertőzött egyedekhez képest.

Az önocita markerek a mézelö méh önocitákon, D. melanogaster lamellocita alpopuláción és kristálysejteken és B. mori önocitoidokon fejeződnek ki. Lepidoptera fajokban az önociták melanizálódnak (Lavine és Strand, 2002), ahogy a D. melanogaster kristálysejtek, vagy a B. mori önocitoidok (Beaulaton, 1979, Rizki és Rizki, 1984). D. melanogaster-ben aktiválódnak a melanizációs kaszkád enzimei, a folyamat egyik legfontosabb enzime a fenoloxidáz, amelynek zimogén formája a profenoloxidáz (PPO) (Biedermann és Moritz, 1898, Cerenius és mtsai., 2008, Kanost és Gorman, 2008). Az ecetmuslica három PPO-zal rendelkezik (Binggeli és mtsai., 2014, Dudzic és mtsai., 2015), sérülést követően a kristálysejtek PPO1-t és PPO2-t termelnek. Darázsfertőzés során a PPO3 is aktiválódik a harmadik vérsejttípusban a lamellocitákban, és a kristálysejtek termelte PPO2-vel együttmüködve részt vesz a parazita pete körül képződött többsejtrétegü tok melanizálásában (Dudzic és mtsai., 2015). A mézelő méhben csupán egy PPO-t azonosítottak (Consortium, 2006, Elsik és mtsai., 2014), a fehérjét mind a kutikulából (Colonello és mtsai., 2003), mind a hemolimfából (Zufelato és mtsai., 2004) kimutatták. Az aktív enzim molekulatömege 74,4 kDa (Lourenço és mtsai., 2005), ami egybe esik a 2.28 önocita marker molekulatömegével ( $\sim 75 \mathrm{kDa})$ és annak dimerizált formájával $(\sim 150$ kDa). Feltételezhetően az AmPPO nem képez dimereket (Zufelato és mtsai., 2004), azonban a folyamat jellemző a fenoloxidázokra (Ashida, 1971, Jiang és mtsai., 1997, Kwon és mtsai., 1997). Összehasonlítottuk az AmPPO fehérjeszekvenciáját a DmPPO-okéval (PPO1, PPO2, PPO3) CLUSTALW analízissel 
(http://www.genome.jp/tools/clustalw/). Az összehasonlítás 47\%-60\%-os azonosságot mutatott. Ezek alapján feltételezzük, hogy a 2.28 ellenanyag az AmPPO-t ismeri fel, azonban ennek bizonyításához további kísérletekre van szükség. Tervezzük DmPPO mutánsok vérsejtjeinek vizsgálatát a 2.28 ellenanyaggal immunhisztokémiai és immunfluoreszcens módszerekkel.

A granulociták, amelyek expresszálják a granulocita-önocita markereket, a mikroorganizmusok bekebelezését végzik. A vérsejteknek csupán $22 \%$-a fagocitál fiatal dolgozókban. A fagocitáló sejtek aránya alacsonyabb a kizárólag egyedi immunitással rendelkező $D$. melanogaster fajhoz képest, ahol a plazmatociták a fagocitáló sejtek, és a vérsejtek többségét (>95\%) képezik (Rizki és Rizki., 1984). A már említett, szociális fajokra jellemző, alternatív stratégiák miatt, valószínűleg kevesebb kórokozó mikroorganizmus jut a méhek testüregébe, amit fagocitózissal pusztítanának el, így feltételezhetően az evolúció során nem volt erős szelekciós nyomás a fagocitáló sejtek irányába. Csupán néhány parazita és mikrobiális fertőzés vizsgálatakor mutattak ki változást a sejt-közvetítette immunválaszban. Ssc1fertőzés során kimutatták, hogy csökken a vérsejtek száma a nem fertőzött egyedekhez képest (Burritt és mtsai., 2016). S. melliferum fertőzés esetén növekszik a granulociták aránya, majd a plazmatocitáké is a nem fertőzött egyedekhez képest (Yang és mtsai., 2017).

Korábban a mézelő méh vérsejtjeit áramlási citometriával vizsgálták fluoreszcensen jelölt lektinek alkalmazásával, azonban ezzel a módszerrel a különböző vérsejttípusok nem voltak nyomon követhetők, szükségessé vált egy vérsejtekre specifikus jelölési rendszer. Eredményeink szerint az általunk azonosított immunológiai markerek alkalmasak a funkciójukban egymástól különböző vérsejtek áramlási citometriás vizsgálatára.

A vérsejtképződésben jelentős szerepet játszanak a vérsejtképző szövetek. Az egyik legjobban tanulmányozott faj a vérsejtképződés modellezésében a $D$. melanogaster. Az ecetmuslica lárva vérsejtjeinek jelentős része a hemolimfában kering, azonban megfigyeltek helyhez kötött vérsejt populációkat is, amelyek a vérsejtek képzéséért felelösek, mint a központi nyirokszerv és a szesszilis szövet (Lanot és mtsai., 2001, Márkus és mtsai., 2009, Sorrentino és mtsai., 2002, Zettervall és mtsai., 2004). Egyéb rovar fajokban is sikerült azonosítani vérsejtképző szöveteket a szívcső környezetében (Böhm és Gersch, 1983, Gardiner és Strand, 2000, Han és mtsai., 1998, Hoffmann, 1970, Hoffmann 1979, Nakahara és mtsai., 2010, Nardi és mtsai., 2003), azonban eddig az immunológiai markerekkel végzett ez irányú kísérleteink negatív eredménnyel zárultak. 
A mézelő méh egyedfejlődése során egymástól különböző vérsejttípusokat azonosítottak (Negri és mtsai., 2014), továbbá eltérés van a vérsejtek számában és a hemolimfa fenoloxidáz aktivitásában is. A lárvális és báb stádiumokban a legmagasabb a vérsejtek száma, és a fenoloxidáz aktivitás folyamatosan emelkedik a fejlődés során mindhárom kasztban (Laughton és mtsai., 2011, Schmid és mtsai., 2008, Wilson-Rich és mtsai., 2008). Az áttelelő méhekben megemelkedik a vérsejtek száma (Burritt és mtsai., 2016). Hystad és munkatársai leírták, hogy a fiatalabb gondozó méhek vérsejtjei jobban fagocitálnak, mint az idős gyüjtő és az áttelelő méhek vérsejtjei (Hystad és mtsai., 2017). Megállapítottuk, hogy a vérsejtek markerexpressziója is megváltozik a fejlődés során. A kis kerek és óriás plazmatociták is expresszálják a plazmatocita markereket lárvális állapotban, feltételezhetően egy vonalból származik a két sejtpopuláció. A plazmatociták aránya magasabb az adultokban a lárvákhoz képest, míg a granulocita-önocita markert kifejező sejtek aránya alacsonyabb lesz. A granulocita-önocita marker adult állatokban a granulocitákon és az önocitákon fejeződik ki, a plazmatocitákon nem, amiből arra következtethetünk, hogy a plazmatociták a granulocitáktól és az önocitáktól eltérő leszármazási vonalból differenciálódnak. Ez alapján feltételezhetjük azt is, hogy a granulociták és az önociták azonos eredetủek, esetleg képesek transzdifferenciációra, hasonlóan a D. melanogaster fagocitáló sejtjeihez, amelyek képesek kristálysejtekké alakulni (Leitão és Sucena, 2015). Ez alapján megállapítottuk, hogy a vérsejtek immunológiai fenotípusa az egyedfejlődés során jellegzetesen változik. Elmondhatjuk, hogy a markerek vizsgálatával tanulmányozni tudjuk a vérsejtekben bekövetkező változásokat az egyedfejlődés során és következtethetünk azok leszármazási vonalaira.

A három kaszt összehasonlítása során kimutatták, hogy különbség van a fenoloxidáz aktivitásban és az antimikrobiális peptidek termelésében különböző kezelések hatására (Brandt és mtsai., 2016, Gätschenberger és mtsai., 2013, Laughton és mtsai., 2011, Schmid és mtsai., 2008). Neonikotinoiddal történő kezelés hatására csökken a vérsejtek száma, a melanizációs aktivitás és a hemolimfa antimikrobiális aktivitása dolgozókban és méhanyákban (Brandt és mtsai., 2016, 2017). A különböző vérsejt populációk arányában nem találtunk különbséget a kasztok között, ami következhet abból, hogy a vérsejt populációk aránya azonos mértékben csökken.

A mezőgazdaságban növényvédelmi okokból elterjedt a neonikotinoidok csávázószerként történő használata. Neonikotinoidok hatására a méhek idegrendszerében elváltozások észlelhetők, elvesztik tájékozódási képességüket (Fairbrother és mtsai., 2014). Laboratóriumi körülmények között végzett kísérletek eredményei alapján a 
neonikotinoiddal történő kezelés hatására csökken a vérsejtek száma és melanizációs aktivitása (Brandt és mtsai., 2016, 2017). A neonikotinoidok hatását a sejt-közvetítette immunválaszra neonikotinoiddal csávázott vetőmaggal bevetett méhlegelőn gyüjtött méhekből végeztük. Brandt és munkatársai az immunrendszerben bekövetkező változások kimutatása során közvetlenül kezelték a méheket a szerrel. Mi a terepen végzett kísérletek során nem tapasztaltunk változást a plazmatociták arányában, amely következhet abból, hogy az irodalomban kimutatott vérsejtszám csökkenés nincs hatással a plazmatociták arányára, de az is lehetséges, hogy a vegyszer közvetve a növényen át bejuttatva a méhek szervezetébe nincs hatással az immunválaszra kísérleti körülmények között, laboratóriumban elvégzett, a méhekkel közvetlenül érintkező kezeléshez képest.

Megvizsgáltuk a plazmatociták arányának változását az atkagyérítésre használt amitráz kezelés során, valamint a VSH és nem VSH méhvonalak egyedeiben. Nem volt szignifikáns különbség az amitráz kezelés hatására a plazmatociták arányában, ahogyan a VSH és kontroll családok egyedei között sem. Marringa és munkatársai leírták, hogy a permeabilizált sejtek és a plazmatociták aránya magasabb az atkafertőzött kolóniákban (Marringa és mtsai., 2014), azonban mi nem mutattunk ki szignifikáns különbséget az atkafertőzött és kontroll családok egyedei között.

A vérsejtek funkcionális vizsgálata során megállapítottuk, hogy a mézelő méhben immunindukciót követően (steril szúrás, atkafertőzés, vegyszeres kezelés, idegen makropartikulumok a szervezetben) nem differenciálódnak új vérsejttípusok, mint a kizárólag egyedi immunitással rendelkező Drosophila fajokban, a sejt-közvetítette folyamatok aktiválódása előtt egyéb, alternatív védekezési mechanizmusok mehetnek végbe. Az első, a mechanikai védelmi vonal is feltehetően kiemelt szerepet játszik, a védekezésben, ezért a mézelő méhben is megvizsgáltuk a Drosophila-ban azonosított kutikulához kapcsolt Vajk fehérjék kimutatását.

A fizikai elhatárolás fontos a fertőzések elleni védekezésben. D. melanogaster-ben a Vajk1 és Vajk4 fehérjék megtalálhatóak a kutikulában. A fehérjéket kódoló gének a Nimród génklaszter tagjai, amelynek génjei a fagocitózisban szerepet játszó Nimrod fehérjéket kódolják (Kurucz és mtsai., 2007a, Somogyi és mtsai., 2008, Somogyi és mtsai., 2010, Zsámboki és mtsai., 2013). A géncsalád több tagjával homológ gént azonosítottak mézelő méhben is (Somogyi és mtsai., 2010). Western blot eljárással kimutattuk, hogy a Vajk4 fehérje kifejeződik késői bábokban, feltételezhetően sokkal kisebb mennyiségben, mint ecetmuslicában, ami arra utal, hogy a kutikuláris Vajk fehérjék homológjai kevésbé 
járulnak hozzá mézelő méhben az elsődleges védelmi vonal felépítéséhez, mint az ecetmuslicában.

A méhek egyedi immunitása mellett megfigyeltek a szociális berendezkedésből adódó alternatív védekezési folyamatokat is, amelyek kiegészíthetik az egyedi immunitást (Alaux és mtsai., 2012, Richard és mtsai., 2008, Evans és Spivak, 2010, Wilson-Rich és mtsai., 2009). Feltételezhetően a mézelő méh genomban ezért is azonosítottak kevesebb immunfehérjét kódoló gént (Evans és mtsai., 2006, Harpur és Zayed, 2013).

Létrehoztunk egy olyan kísérleti eljárást, amelynek segítségével a mézelő méh vérsejt populációi azonosíthatók és könnyen elkülöníthetők egymástól. A markerek alkalmasak a vérsejtek jellemzésére, lehetőséget biztosítottak a funkcióikban egymástól különböző vérsejtek azonosítására és nyomon követésére. A molekuláris markerek használata korábban egyéb fajokban is hasznosnak bizonyult a vérsejtek funkciójának részletes megismeréséhez, valamint a vérsejtképződés és sejtvonalak feltérképezéséhez (Arai és mtsai., 2013, Kurucz és mtsai., 2007b). A mézelő méh sejt-közvetítette immunitásának tanulmányozása hozzájárulhat olyan gyakorlati megoldások fejlődéséhez, amelyek segíthetnek a méheket fenyegető biotikus és abiotikus hatások legyőzésében (Bull és mtsai., 2012, Chan és mtsai., 2009, Evans és Schwarz, 2011, Farooqui, 2013, SimonDelso és mtsai., 2014, vanEngelsdorp és mtsai., 2009). 


\section{Az eredmények összefoglalása}

A mézelö méh a Hymenoptera rendbe tartozó, kolóniákban élö, kozmopolita elterjedésű rovar (Winston, 1987). Az egyik legfontosabb faj a növények beporzásában, ezáltal a biodiverzitás fenntartásában valamint pótolhatatlan egyes kozmetikai, gyógyszeripari élelmiszeripari alapanyagok előállításában és a méztermelésben. A kolóniákat különböző mikróbák és paraziták károsítják, amelyekkel szembeni védekezésben immunrendszerének kitüntetett szerepe van. A kolóniák tömeges pusztulása az utóbbi években világszerte egyre gyakoribbá vált, súlyos gazdasági következményeket vonva maga után (Daniat és mtsai., 2012, Moritz és mtsai., 2010). A gazdasági károk csökkentése érdekében, fontos megismernünk a kórokozó és gazdaszervezet közötti kölcsönhatásokat, amelyhez elsősorban a gazdaszervezet immunrendszerének megismerésén keresztül vezet az út.

A mézelö méh, a többi rovarfajhoz hasonlóan, humorális és sejt-közvetítette immunitással rendelkezik, amelyeknek fó elemei az antimikrobiális peptidek, és a vérsejtek (Evans és mtsai., 2006). Mivel szociális faj, az immunológiai védekezés mellett alternatív védekezési stratégiákat is alkalmaz, mint például a tisztogatási tevékenység vagy a „kaptárláz”, ezért immunrendszere, a korábban tanulmányozott modellszervezetekhez képest, speciális elemeket tartalmazhat (Richard és mtsai., 2008, Wilson-Rich és mtsai., 2009). A mézelő méhből eddig azonosított humorális komponensek száma alacsonyabb a nem szociális D. melanogaster fajhoz képest, azonban kevés információ áll rendelkezésünkre a sejt-közvetítette immunválaszáról (Consortium, 2006, Evans és mtsai., 2006, Elsik és mtsai., 2014). Hemolimfájában vérsejtek, az ún. hemociták, keringenek, amelyeket eddig többnyire morfológiai jegyek és lektinkötési képességük alapján csoportosítottak, azonban sem a funkciójuk, sem az eredetük nem ismert, és vérsejtképző szövetek meglétéröl sem tudunk. Szükség van egy olyan specifikus molekuláris módszerre, amelynek alkalmazásával a funkciójukban egymástól különböző vérsejttípusokat el tudjuk különíteni egymástól (deGraaf és mtsai., 2002, Negri és mtsai., 2016).

Célunk a mézelö méh vérsejtjeinek jellemzésére alkalmas vizsgálati rendszer létrehozása volt, amelyet korábban már sikeresen alkalmaztak különböző Drosophila fajokban (Kurucz és mtsai., 2007b, Márkus és mtsai., 2015). Munkánk során immunológiai markereket azonosítottunk, amelyeket a lárva és a kifejlett egyed keringő vérsejtjein mutatott reakciómintázatuk alapján csoportosítottunk, valamint kapcsolatot kerestünk a markerek kifejeződése és a vérsejtek funkciója között. 
Három fô vérsejttípust azonosítottunk immunhisztokémiai és immunfluoreszcens módszerekkel, és megvizsgáltuk a különböző vérsejttípusoknak a sejt-közvetítette immunválaszban játszott szerepét. A mikroorganizmusok bekebelezését fluoreszcensen jelölt baktériumokkal, a nagyobb méretű kórokozók elhatárolását az egyedekben elhelyezett damil szállal vizsgáltuk. Megfigyeltük a vérsejtek melanizációját, valamint alvadékképzését. Nyomon követtük a vérsejtek arányában bekövetkező változást különböző, a termelői méhészetekben is előforduló kémiai vegyszerek és atkafertőzés hatására.

Kísérleteinkben azonosítottunk a plazmatocitákra jellemző markereket, amelyeknek a segítségével megfigyeltük, hogy a plazmatociták aránya a fejlődés során megemelkedik. Képesek aggregátumokat létrehozni, amellyel a testüregben elhatárolhatják a nagyobb méretü kórokozókat szöveti környezetüktől. Kimutattuk, Western blot, immunprecipitáció és LC-MS/MS analízissel, hogy a 4E1 plazmatocita marker a mézelő méh hemolektin (AmHml). Eredményeinket RNS interferenciával erősítettük meg (Gábor és mtsai., 2017). Az önocita markerek a melanizációért felelős sejteket jelölték ki, amelyek aránya nem változik a fejlődés során. A markerek expresszálódnak a nagyobb méretü testidegen anyag körüli aggregátumban is. Az önocita markerek megtalálhatók D. melanogaster kristálysejtekben és a lamellociták egy részében, ezek a sejtek a felelősek a tokképzés és sebgyógyulás során zajló melanizációs folyamatokért. Meghatároztuk a 2.28 önocita marker molekulatömegét ( 75 és $\sim 150 \quad \mathrm{kDa})$. A mézelő méh profenoloxidáz molekulatömege 74,4 kDa (Lourenço és mtsai., 2005). A granulocita-önocita markerek a lárvákban minden vérsejten megtalálhatók, expressziójuk a fejlődés során csökken, a kifejlett egyedekben már csak a granulocitákon és az önocitákon vannak jelen. A granulociták képesek a mikroorganizmusok bekebelezésére (26. ábra).

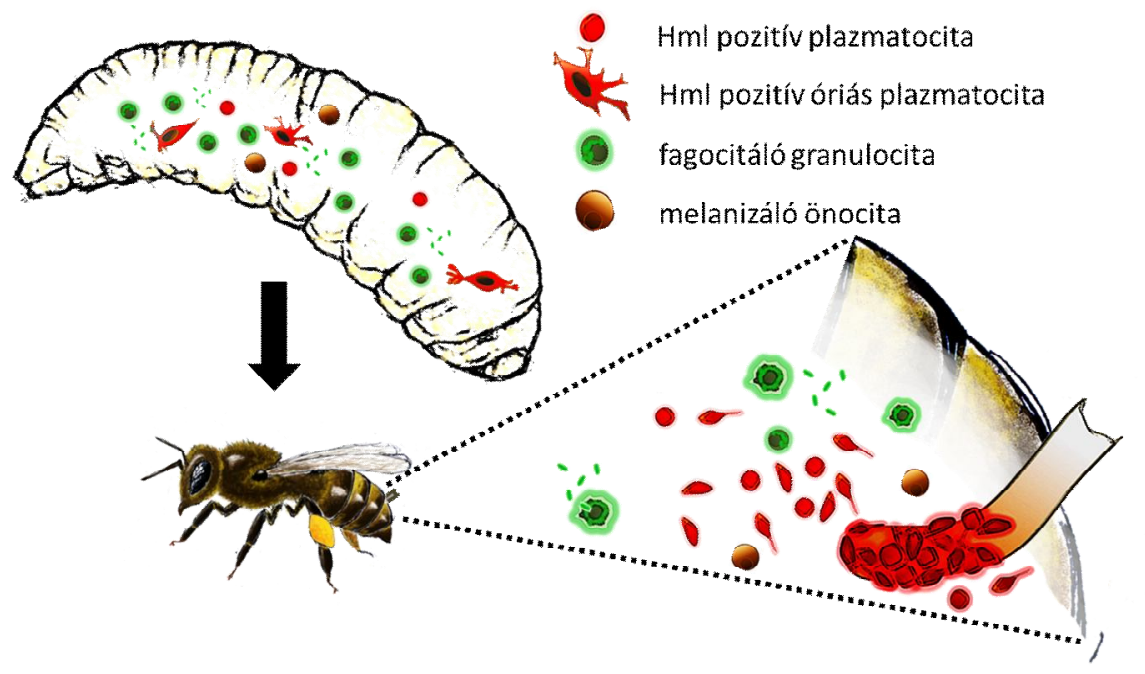

26. ábra A mézelő méh fó vérsejttípusai lárvákban és kifejlett egyedekben. A molekuláris markerek és funkcionális tesztek segítségével három fő vérsejttípust különítettünk el: a Hml pozitív plazmatocitákat, a fagocitáló granulocitákat és a melanizáló önocitákat. 
Az AmHml marker nyomon követésével megvizsgáltuk, hogy a neonikotinoiddal csávázott méhlegelö, vagy az amitráz kezelés hatással van-e a sejt-közvetítette immunválaszra, valamint, hogy van-e különbség a VSH és nem VSH vonalakból származó méhcsaládok és az atkával fertőzött vagy nem fertőzött egyedek között. Nem tapasztaltunk a különböző kezeléseknél és méhvonalaknál különbséget a vizsgálatok során.

A veleszületett immunitás mellett, az első egyik legfontosabb mechanikai védekezés az elhatárolás. A kutikula határolja el a szervezetet a környezeti hatásoktól. Kísérleteink során megvizsgáltuk a $D$. melanogaster bábok kutikulájában kifejeződő Vajk fehérjéket (Cinege és mtsai., 2017). Kimutattuk Western blot eljárással, hogy a Vajk 4 fehérje mézelő méh bábokban is megtalálható.

Munkánk során immunológiai markereket azonosítottunk, amelyek jellemzik a különböző vérsejttípusokat. A vérsejt alpopulációkra specifikus markerekkel azonosítottuk az alvadékképződésben szerepet játszó AmHml-t. A markerek használatával megvizsgálhatjuk a vérsejtekben bekövetkező változásokat fertőzések és károsító tényezők hatására. Vizsgálatainkkal bővíteni szeretnénk a méhek immunitásáról szerzett eddigi ismereteket, amelyek alapján közelebb kerülhetünk a tömeges kolóniapusztulás által okozott károk okainak megismeréséhez, és a károk okozta anyagi veszteségek enyhítéséhez. 


\section{Summary of the results}

The honeybee (Apis mellifera) is a eusocial insect which belongs to the Hymenoptera ordo (Winston, 1987). The species is not just vital in producing bee products, which are used in food industry, pharmaceutics and cosmetics, but it is also very important in maintaining biodiversity. Honey bee diseases and the Colony Collapse Disorder (CCD) are therefore causing great economic and ecological losses (Daniat et al., 2012, Moritz et al., 2010). To understand the precise mechanism of the multifactorial phenomenon of colony losses it is crucial to understand the honey bee immune defense which is a major factor contributing to fitness of the individuals and of the colony.

Being a social insect it has communal defense mechanisms such as hygienic behavior and hive fever, therefore the honey bee immunity may have unique components (Richard et al., 2008, Wilson-Rich et al., 2009). Similarly to solitary insects it has individual immune system consists of regulatory pathways of the humoral immunity and the cell-mediated responses (Evans et al., 2006). We have a deep understanding of the humoral immunity (Consortium, 2006, Evans et al., 2006, Elsik et al., 2014), however, our knowledge of the cell mediated immunity is far from complete, particularly, how the cellular networks develop and are related to function and to pathogenesis.

The effector cells of the cellular immunity are the blood cells, so called hemocytes, which engulf microorganisms, produce antimicrobial peptides and form capsules around intruders which are too big to be taken up by phagocytosis. Compared to the elements of the humoral responses, the mechanism of the cell mediated immunity is much less understood. So far, hemocytes were identified by morphological criteria and their lectin binding properties, which resulted in the description of several, ill-characterized hemocyte subsets. However, due to the lack of molecular markers for these cells the results are controversial. A more specific method would be necessary to study the function of the different blood cell types, to follow their differentiation and to reveal the hematopoiesis of the honey bee (deGraaf et al., 2002, Negri et al., 2016).

We developed an antibody-based toolkit for the characterization and classification of the honeybee hemocytes by cell-type specific antigens. In order to find molecular markers for functional subsets of blood cells, first, we raised a set of monoclonal antibodies to larval and adult hemocytes, similarly to Drosophila species (Kurucz et al., 2007b, Márkus et al., 2015). In our experiments 'in vivo' and 'in vitro' immunological and molecular technics were used, including hybridoma production, immunofluorescence and 
immunohistochemical methods. For the phagocytosis assay we used fluorescence labeled bacteria and for modeling the encapsulation response we used a plastic fiber threaded through the bees' abdomen. We studied the melanisation and coagulation of the blood cells and followed the differentiation in the blood cell populations in mite parasitized animals as well as the effect of chemicals used in beekeeping and in the agriculture.

With the combination of a defined marker panel and functional tests we distinguished three main classes of hemocytes: the aggregating plasmatocytes, the melanizing oenocytes and the phagocytic granulocytes.

We identified markers specific for the plasmatocytes. With the help of the plasmatocyte markers we found, that the proportion of the marker positive cells is increasing through the development. The plasmatocytes form cell-aggregates around a plastic fiber which demonstrates their ability to isolate foreign particles. In the clot formation assay these cells built up a fiber matrix in the coagulum. In Western-blot and LC-MS/MS analysis as well as in RNA interference the plasmatocyte specific marker was identified as the AmHml (Gábor et al., 2017). The oenocyte marker proteins are expressed on the melanizing cells and are present in the aggregate formed around the plastic fiber. They might be conserved elements of the melanisation cascade, as the D. melanogaster larval crystal cells which are responsible for the melanisation and the encapsulating cells, the lamellocytes were marker positive too. The 2.28 oenocyte marker is detected at $\sim 75 \mathrm{kDa}$ and $\sim 150 \mathrm{kDa}$ in the Western-blot assay. The lower molecular mass band shows the same molecular mass as the honey bee prophenoloxidase (Lourenço et al., 2005). The granulocyte-oenocyte marker is expressed on granulocytes and oenocytes in the adult and in all hemocyte types in the larva; the expression of the markers are decreasing through the development. The granulocytes take up microorganisms by phagocytosis (Fig. 27.).

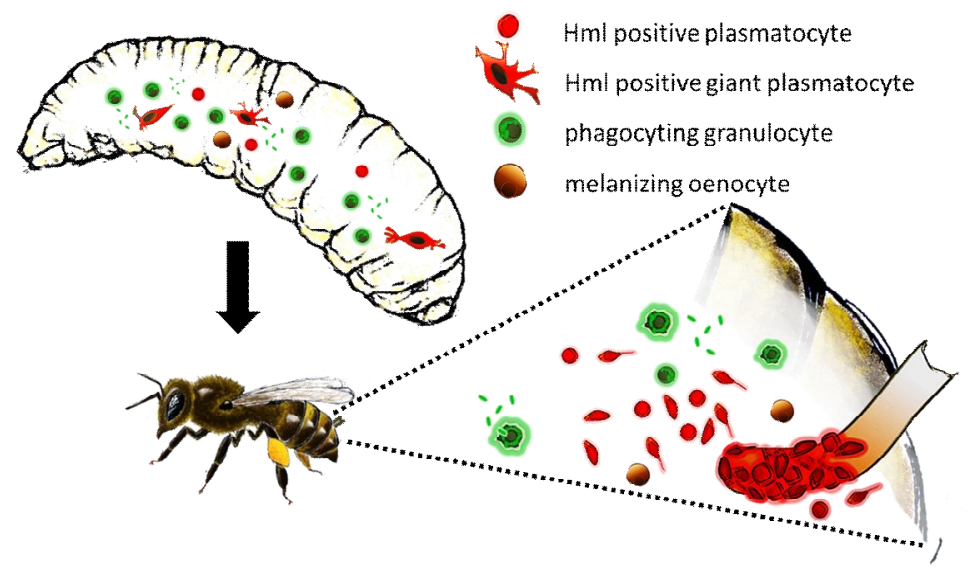

Fig. 27. The main blood cell types of the honey bee in the larva and in the adult. With the aid of molecular markers and functional tests we identified three main blood cell types: the Hml positive plasmatocytes, the phagocyting granulocytes and the melanizing oenocytes. 
By using the AmHml antibody we marked the blood cells of honeybees kept in neonicotinoid treated sunflower, bees treated with amitraz, and the differences between VSH versus non VSH bee lines and mite infected versus non-infected individuals. We did not record significant changes in the ratio of blood cell types.

The first line of the defense is the protection of the organism from the external mechanical damages. In insects the cuticle is responsible for this function. We investigated the expression of Vajk proteins which are expressed in the cuticle of D. melanogaster pupae (Cinege et al., 2017) and also have been predicted to be expressed in the honey bee too (Kurucz et al., 2007a, Somogyi et al., 2010, Zsámboki et al., 2013). We formally showed the presence of the Vajk 4 protein in honey bee pupae by Western blot analysis.

Our work led to the identification of immunological markers, which are specific for the different blood cell populations. These markers can be used for monitoring the response of the cellular components of the immune system to harmful substances. We have identified the AmHml as a key component in the aggregation and coagulation reactions to foreign particles. Our studies expand the knowledge of the honey bee cell mediated immunity, and we anticipate that they will lead to a better understanding of immune defense against parasites and microbes and harmful agents in the honey bee. 


\section{Köszönetnyilvánítás}

Köszönöm témavezetőmnek, Prof. Dr. Andó Istvánnak a lehetőséget, hogy a csoportjában végezhettem diákköri és Ph.D. munkámat. Köszönöm bizalmát, tapasztalatait, hasznos tanácsait, ötleteit és türelmét, amivel segítette munkámat, valamint biztosította a munkámhoz a megfelelő feltételeket.

Köszönöm társ-témavezetőmnek Dr. Kurucz Judit Évának, hogy bevezetett az immunológiai biokémiai és molekuláris biológiai módszerekbe.

Köszönöm Dr. Cinege Gyöngyinek önzetlen segítségét és tanácsait a molekuláris biológiai kísérletek során.

Köszönöm a segítségét, hasznos ötleteit munkatársaimnak: Dr. Csordás Gábornak, Dr. Kari Beátának, Lerner Zitának, Dr. Honti Viktornak, Varga Gergelynek, Dr. Zsámboki Jánosnak.

Köszönöm laboratóriumunk asszisztenseinek: Balázs Anitának, Ilyés Mónikának, Képíró Anikónak, Kovalcsik Olgának és Tápai Szilviának, hogy bevezettek a kutatás gyakorlati módszereibe.

Köszönöm Dr. Török Tibornak, a kutatás nélkülözhetetlen kísérleti alanyainak, a mézelö méheknek a biztosítását, és a méhek tartásával, szerveződésével kapcsolatos méhészeti ismereteimet.

Köszönöm Prof. Dr. Békési Lászlónak, Dr. Zajácz Editnek, Prof. Dr. Rusvai Miklósnak, Dr. Mándoki Mirának, Dr. Bősze Zsuzsának, Dr. Stéger Viktornak, Dr. Kolics Balázsnak, Bengyák Vincének, Dr. Paulus Petrának, Dr. Papp Melittának a segítséget és hasznos ötleteket, valamint, hogy biztosították a különböző vegyszeres kezelések és méhvonalak vizsgálata során alkalmazott egyedeket.

Köszönöm Dr. Gácser Attilának és Dr. Jankovics Ferencnek a dolgozatom bírálatát.

Köszönettel tartozom Dr. Erdélyi Miklósnak, a Szegedi Biológiai Kutatóközpont Genetikai Intézet igazgatójának a támogatását, ahhoz, hogy a Genetikai Intézetben végezhettem diákköri és Ph.D. munkámat.

Köszönettel tartozom Dr. Jankovics Ferencnek, Dr. Henn Lászlónak, Dr. Darula Zsuzsannának és Kotogány Editnek tanácsaikat és segítségüket a kísérletek során.

Végül, de nem utolsó sorban szeretném megköszönni a családomnak, szüleimnek, barátaimnak és méhésztársaimnak azt, hogy mindvégig támogattak és mellettem álltak.

A Ph.D. fokozat megszerzését a következő pályázatok tették lehetővé: NKFI K 120140; GINOP-2.3.2-15-2016-00001; GINOP-2.3.2-15-2016-00035. 


\section{Irodalomjegyzék}

Agaisse, H., Petersen, U.M., Boutros, M., Mathey-Prevot, B., Perrimon, N., 2003. Signaling role of hemocytes in Drosophila JAK/STAT-dependent response to septic injury. Dev. Cell 5, 441-450.

Alaux, C., Kemper, N., Kretzschmar, A., Le Conte, Y., 2012. Brain, physiological and behavioral modulation induced by immune stimulation in honeybees (Apis mellifera): a potential mediator of social immunity? Brain Behav. Immun. 26, 1057-1060.

Alippi, A.M., López, A.C., Aguilar, O.M., 2002. Differentiation of Paenibacillus larvae subsp. larvae, the cause of American foulbrood of honeybees, by using PCR and restriction fragment analysis of genes encoding 16S rRNA. Appl. Environ. Microbiol. $68,3655-3660$.

Amaral, I.M.R., Moreira Neto, J.F., Pereira, G.B., Franco, M.B., Beletti, M.E., Kerr, W.E., Bonetti, A.M., Ueira-Vieira, C., 2010. Circulating hemocytes from larvae of Melipona scutellaris (Hymenoptera, Apidae, Meliponini): cell types and their role in phagocytosis. Micron 41, 123-129.

Anderson, D.L., Trueman, J.W., 2000. Varroa jacobsoni (Acari: Varroidae) is more than one species. Exp. Appl. Acarol. 24, 165-189.

Arai, I., Ohta, M., Suzuki, A., Tanaka, S., Yoshizawa, Y., Sato, R., 2013. Immunohistochemical analysis of the role of hemocytin in nodule formation in the larvae of the silkworm, Bombyx mori. J. Insect Sci. 13, 125.

Arai, R., Miyoshi-Akiyama, T., Okumura, K., Morinaga, Y., Wu, M., Sugimura, Y., Yoshiyama, M., Okura, M., Kirikae, T., Takamatsu, D., 2014. Development of duplex PCR assay for detection and differentiation of typical and atypical Melissococcus plutonius strains. J. Vet. Med. Sci. 76, 491-498.

Armitage, S.A.O., Boomsma, J.J., 2010. The effects of age and social interactions on innate immunity in a leaf-cutting ant. J. Insect Physiol. 56, 780-787.

Arnot, C.J., Gay, N.J., Gangloff, M., 2010. Molecular mechanism that induces activation of Spätzle, the ligand for the Drosophila Toll receptor. J. Biol. Chem. 285, 1950219509.

Aronstein, K.A., Murray, K.D., 2010. Chalkbrood disease in honey bees. J. Invertebr. Pathol. 103 Suppl 1, S20-29. 
Ashida, M., 1971. Purification and characterization of pre-phenoloxidase from hemolymph of the silkworm Bombyx mori. Arch. Biochem. Biophys. 144, 749-762.

Bailey, L., Ball, B.V., Perry, J.N., 1983. Association of viruses with two protozoal pathogens of the honey bee. Annals of Applied Biology 103, 13-20.

Beetsma, J. (Department of E., 1994. The Varroa mite, a devastating parasite of western honeybees and an economic threat to beekeeping. Outlook on Agriculture (United Kingdom).

Beaulaton, J., 1979. Hemocytes and hemocytopoiesis in Silkworms. Biochimie 61, 157164.

Bidla, G., Lindgren, M., Theopold, U., Dushay, M.S., 2005. Hemolymph coagulation and phenoloxidase in Drosophila larvae. Developmental \& Comparative Immunology 29, 669-679.

Bidla, G., Hauling, T., Dushay, M.S., Theopold, U., 2009. Activation of insect phenoloxidase after injury: endogenous versus foreign elicitors. J Innate Immun 1, 301308.

Biedermann, W., Moritz, P., 1898. Beiträge zur vergleichenden Physiologie der Verdauung. Pflüger, Arch. 73, 219-287.

Binggeli, O., Neyen, C., Poidevin, M., Lemaitre, B., 2014. Prophenoloxidase activation is required for survival to microbial infections in Drosophila. PLoS Pathog. 10, e1004067.

Böhm, G.A., Gersch, M., 1983. The hemopoietic character of the "cephalic gland" in the crayfish Orconectes limosus. Gen. Comp. Endocrinol. 52, 102-107.

Brandt, A., Gorenflo, A., Siede, R., Meixner, M., Büchler, R., 2016. The neonicotinoids thiacloprid, imidacloprid, and clothianidin affect the immunocompetence of honey bees (Apis mellifera L.). J. Insect Physiol. 86, 40-47.

Brandt, A., Grikscheit, K., Siede, R., Grosse, R., Meixner, M.D., Büchler, R., 2017. Immunosuppression in Honeybee Queens by the Neonicotinoids Thiacloprid and Clothianidin. Sci Rep 7, 4673.

Braun, A., Lemaitre, B., Lanot, R., Zachary, D., Meister, M., 1997. Drosophila immunity: analysis of larval hemocytes by P-element-mediated enhancer trap. Genetics 147, 623634. 
Bull, J.C., Ryabov, E.V., Prince, G., Mead, A., Zhang, C., Baxter, L.A., Pell, J.K., Osborne, J.L., Chandler, D., 2012. A Strong Immune Response in Young Adult Honeybees Masks Their Increased Susceptibility to Infection Compared to Older Bees. PLoS Pathog 8, e1003083.

Burlando, B., Cornara, L., 2013. Honey in dermatology and skin care: a review. J Cosmet Dermatol 12, 306-313.

Burritt, N.L., Foss, N.J., Neeno-Eckwall, E.C., Church, J.O., Hilger, A.M., Hildebrand, J.A., Warshauer, D.M., Perna, N.T., Burritt, J.B., 2016. Sepsis and Hemocyte Loss in Honey Bees (Apis mellifera) Infected with Serratia marcescens Strain Sicaria. PLoS ONE 11, e0167752.

Carton, Y., Nappi, A.J., 1997. Drosophila cellular immunity against parasitoids. Parasitol. Today (Regul. Ed.) 13, 218-227.

Cerenius, L., Söderhäll, K., 2004. The prophenoloxidase-activating system in invertebrates. Immunol. Rev. 198, 116-126.

Cerenius, L., Lee, B.L., Söderhäll, K., 2008. The proPO-system: pros and cons for its role in invertebrate immunity. Trends Immunol. 29, 263-271.

Cerenius, L., Söderhäll, K., 2011. Coagulation in invertebrates. J Innate Immun 3, 3-8.

Chan, Q.W.T., Melathopoulos, A.P., Pernal, S.F., Foster, L.J., 2009. The innate immune and systemic response in honey bees to a bacterial pathogen, Paenibacillus larvae. BMC Genomics 10, 387.

Chen, Y.P., Siede, R., 2007. Honey bee viruses. Adv. Virus Res. 70, 33-80.

Cherniack, E.P., 2010. Bugs as drugs, Part 1: Insects: the "new" alternative medicine for the 21 st century? Altern Med Rev 15, 124-135.

Cinege, G., Zsámboki, J., Vidal-Quadras, M., Uv, A., Csordás, G., Honti, V., Gábor, E., Hegedűs, Z., Varga, G.I.B., Kovács, A.L., Juhász, G., Williams, M.J., Andó, I., Kurucz, É., 2017. Genes encoding cuticular proteins are components of the Nimrod gene cluster in Drosophila. Insect Biochem. Mol. Biol. 87, 45-54.

Clark, T.B., Whitecomb, R.F., Tully, J.G., Mouches, C., Saillard, C., Bové, J.M., Wroblewski, H., Carle, P., Rose, D.L., Henegar R.B., Williamson, D.L., 1985. 
Spiroplasma melliferum, a new species from the honeybee (Apis mellifera). International journal of systematic bacteriology 35, 296-308.

Colonello, N.A., Zufelato, M.S., Simões, Z.L.P., Bitondi, M.M.G., 2003. In vitro secretion of ecdysteroid-dependent proteins and of a $70 \mathrm{kDa}$ subunit reactive to antiprophenoloxidase serum by Apis mellifera integument. Apidologie 34, 377-388.

Core, A., Runckel, C., Ivers, J., Quock, C., Siapno, T., Denault, S., Brown, B., Derisi, J., Smith, C.D., Hafernik, J., 2012. A new threat to honey bees, the parasitic phorid fly Apocephalus borealis. PLoS ONE 7, e29639.

Cremer, S., Armitage, S.A.O., Schmid-Hempel, P., 2007. Social immunity. Curr. Biol. 17, R693-702.

Csordás, G., Varga, G.I.B., Honti, V., Jankovics, F., Kurucz, É., Andó, I., 2014. In vivo immunostaining of hemocyte compartments in Drosophila for live imaging. PLoS ONE 9, e98191.

Dainat, B., Evans, J.D., Chen, Y.P., Gauthier, L., Neumann, P., 2012. Predictive markers of honey bee colony collapse. PLoS ONE 7, e32151.

Dudzic, J.P., Kondo, S., Ueda, R., Bergman, C.M., Lemaitre, B., 2015. Drosophila innate immunity: regional and functional specialization of prophenoloxidases. BMC Biol. 13, 81.

Dushay, M.S., Asling, B., Hultmark, D., 1996. Origins of immunity: Relish, a compound Rel-like gene in the antibacterial defense of Drosophila. Proc. Natl. Acad. Sci. U.S.A. 93, 10343-10347.

Dutto, M., Ferrazzi, P., 2014. Megaselia rufipes (Diptera: Phoridae): a new cause of facultative parasitoidism in Apis mellifera. Journal of Apicultural Research 53, 141145 .

El-Mohandes S.S., Nafea, E.A., Fawzi, A.M., 2010. Effect of different feeding diets on the haemolymph of the newly emerged honeybee workers Apis mellifera L. Egypt. Acad. J. Biolog. Sci., 3 (1), 213 - 220

Elsik, C.G., Worley, K.C., Bennett, A.K., Beye, M., Camara, F., Childers, C.P., de Graaf, D.C., Debyser, G., Deng, J., Devreese, B., Elhaik, E., Evans, J.D., Foster, L.J., Graur, D., Guigo, R., HGSC production teams, Hoff, K.J., Holder, M.E., Hudson, M.E., Hunt, G.J., Jiang, H., Joshi, V., Khetani, R.S., Kosarev, P., Kovar, C.L., Ma, J., Maleszka, R., 
Moritz, R.F.A., Munoz-Torres, M.C., Murphy, T.D., Muzny, D.M., Newsham, I.F., Reese, J.T., Robertson, H.M., Robinson, G.E., Rueppell, O., Solovyev, V., Stanke, M., Stolle, E., Tsuruda, J.M., Vaerenbergh, M.V., Waterhouse, R.M., Weaver, D.B., Whitfield, C.W., Wu, Y., Zdobnov, E.M., Zhang, L., Zhu, D., Gibbs, R.A., Honey Bee Genome Sequencing Consortium, 2014. Finding the missing honey bee genes: lessons learned from a genome upgrade. BMC Genomics 15, 86.

Evans, J.D., Aronstein, K., Chen, Y.P., Hetru, C., Imler, J.-L., Jiang, H., Kanost, M., Thompson, G.J., Zou, Z., Hultmark, D., 2006. Immune pathways and defence mechanisms in honey bees Apis mellifera. Insect Mol. Biol. 15, 645-656.

Evans, J.D., Schwarz, R.S., 2011. Bees brought to their knees: microbes affecting honey bee health. Trends Microbiol. 19, 614-620.

Evans, J.D., Spivak, M., 2010. Socialized medicine: individual and communal disease barriers in honey bees. J. Invertebr. Pathol. 103 Supp1 1, S62-72.

Fairbrother, A., Purdy, J., Anderson, T., Fell, R., 2014. Risks of neonicotinoid insecticides to honeybees. Environ. Toxicol. Chem. 33, 719-731.

Farooqui, T., 2013. A potential link among biogenic amines-based pesticides, learning and memory, and colony collapse disorder: a unique hypothesis. Neurochem. Int. 62, 122136.

Fries, I., 1993. Nosema Apis-A Parasite in the Honey Bee Colony. Bee World 74, 5-19.

Fries, I., Feng, F., da Silva, A., Slemenda, S.B., Pieniazek, N.J., 1996. Nosema ceranae $n$. sp. (Microspora, Nosematidae), morphological and molecular characterization of a microsporidian parasite of the Asian honey bee Apis cerana (Hymenoptera, Apidae). European Journal of Protistology 32, 356-365.

Gábor, E., Cinege, G., Csordás, G., Török, T., Folkl-Medzihradszky, K., Darula, Z., Andó, I., Kurucz, É., 2017. Hemolectin expression reveals functional heterogeneity in honey bee (Apis mellifera) hemocytes. Dev. Comp. Immunol. 76, 403-411.

Gallai, N., Salles, J.-M., Settele, J., Vaissière, B.E., 2009. Economic valuation of the vulnerability of world agriculture confronted with pollinator decline. Ecological Economics 68, 810-821.

Gardiner, E.M., Strand, M.R., 2000. Hematopoiesis in larval Pseudoplusia includens and Spodoptera frugiperda. Arch. Insect Biochem. Physiol. 43, 147-164. 
Gätschenberger, H., Azzami, K., Tautz, J., Beier, H., 2013. Antibacterial immune competence of honey bees (Apis mellifera) is adapted to different life stages and environmental risks. PLoS ONE 8, e66415.

Goto, A., Kadowaki, T., Kitagawa, Y., 2003. Drosophila hemolectin gene is expressed in embryonic and larval hemocytes and its knock down causes bleeding defects. Dev. Biol. 264, 582-591.

Goto, A., Kumagai, T., Kumagai, C., Hirose, J., Narita, H., Mori, H., Kadowaki, T., Beck, K., Kitagawa, Y., 2001. A Drosophila haemocyte-specific protein, hemolectin, similar to human von Willebrand factor. Biochem. J. 359, 99-108.

Graaf, D.C. de, Dauwe, R., Walravens, K., Jacobs, F.J., 2002. Flow cytometric analysis of lectin-stained haemocytes of the honeybee (Apis mellifera). Apidologie 33, 571-579.

Gupta, A.P., 1979. Insect Hemocytes: Development, Forms, Functions and Techniques. Cambridge Core.

Han, S.S., Lee, M.H., Kim, W.K., Wago, H., Yoe, S.M., 1998. Hemocytic Differentiation in Hemopoietic Organ of Bombyx mori Larvae. Zool. Sci. 15, 371-379.

Han, S.M., Lee, K.G., Pak, S.C., 2013. Effects of cosmetics containing purified honeybee (Apis mellifera L.) venom on acne vulgaris. J Integr Med 11, 320-326.

Harpur, B.A., Zayed, A., 2013. Accelerated evolution of innate immunity proteins in social insects: adaptive evolution or relaxed constraint? Mol. Biol. Evol. 30, 1665-1674.

Hashimoto, Y., Tabuchi, Y., Sakurai, K., Kutsuna, M., Kurokawa, K., Awasaki, T., Sekimizu, K., Nakanishi, Y., Shiratsuchi, A., 2009. Identification of lipoteichoic acid as a ligand for draper in the phagocytosis of Staphylococcus aureus by Drosophila hemocytes. J. Immunol. 183, 7451-7460.

Helming, L., Gordon, S., 2009. Molecular mediators of macrophage fusion. Trends Cell Biol. 19, 514-522.

Higes, M., Martín, R., Meana, A., 2006. Nosema ceranae, a new microsporidian parasite in honeybees in Europe. J. Invertebr. Pathol. 92, 93-95.

Hoffmann, J.A., 1970. The hemopoietic organs of the two orthopterans Locusta migratoria and Gryllus bimaculatus. Z Zellforsch Mikrosk Anat 106, 451-472. 
Hoffmann J, Zachary D, Hoffmann D, Brehelin M, Porte A. Postembryonic development and differentiation: hemopoietic tissues and their functions in some insects. In: Gupta A, editor. Insect Hemocytes. Cambridge University Press; 1979.

Hoffmann, J.A., Kafatos, F.C., Janeway, C.A., Ezekowitz, R.A., 1999. Phylogenetic perspectives in innate immunity. Science 284, 1313-1318.

Honeybee Genome Sequencing Consortium, 2006. Insights into social insects from the genome of the honeybee Apis mellifera. Nature 443, 931-949.

Honti, V., Kurucz, E., Csordás, G., Laurinyecz, B., Márkus, R., Andó, I., 2009. In vivo detection of lamellocytes in Drosophila melanogaster. Immunol. Lett. 126, 83-84.

Hultmark, D., 2003. Drosophila immunity: paths and patterns. Curr. Opin. Immunol. 15, $12-19$.

Hystad, E.M., Salmela, H., Amdam, G.V., Münch, D., 2017. Hemocyte-mediated phagocytosis differs between honey bee (Apis mellifera) worker castes. PLoS ONE 12, e0184108.

Irving, P., Ubeda, J.-M., Doucet, D., Troxler, L., Lagueux, M., Zachary, D., Hoffmann, J.A., Hetru, C., Meister, M., 2005. New insights into Drosophila larval haemocyte functions through genome-wide analysis. Cell. Microbiol. 7, 335-350.

Iwanaga, S., Kawabata, S., Muta, T., 1998. New types of clotting factors and defense molecules found in horseshoe crab hemolymph: their structures and functions. J. Biochem. 123, 1-15.

Jiang, H., Wang, Y., Ma, C., Kanost, M.R., 1997. Subunit composition of pro-phenol oxidase from Manduca sexta: molecular cloning of subunit ProPO-P1. Insect Biochem. Mol. Biol. 27, 835-850.

Jiravanichpaisal, P., Lee, B.L., Söderhäll, K., 2006. Cell-mediated immunity in arthropods: hematopoiesis, coagulation, melanization and opsonization. Immunobiology 211, 213236.

Jung, S.-H., Evans, C.J., Uemura, C., Banerjee, U., 2005. The Drosophila lymph gland as a developmental model of hematopoiesis. Development 132, 2521-2533.

Kacsoh, B.Z., Bozler, J., Schlenke, T.A., 2014. A role for nematocytes in the cellular immune response of the drosophilid Zaprionus indianus. Parasitology 141, 697-715. 
Kanost, M.R., Gorman, M.J., 2008. Phenoloxidases in insect immunity. Insect immunology 1, 69-96.

Kocks, C., Cho, J.H., Nehme, N., Ulvila, J., Pearson, A.M., Meister, M., Strom, C., Conto, S.L., Hetru, C., Stuart, L.M., Stehle, T., Hoffmann, J.A., Reichhart, J.-M., Ferrandon, D., Rämet, M., Ezekowitz, R.A.B., 2005. Eater, a transmembrane protein mediating phagocytosis of bacterial pathogens in Drosophila. Cell 123, 335-346.

Köhler, G., Milstein, C., 1975. Continuous cultures of fused cells secreting antibody of predefined specificity. Nature 256, 495-497.

Köhler, G., Milstein, C., 1976. Derivation of specific antibody-producing tissue culture and tumor lines by cell fusion. Eur. J. Immunol. 6, 511-519.

Koleoglu, G., Goodwin, P.H., Reyes-Quintana, M., Hamiduzzaman, M.M., GuzmanNovoa, E., 2018. Varroa destructor parasitism reduces hemocyte concentrations and prophenol oxidase gene expression in bees from two populations. Parasitol. Res. 117, $1175-1183$.

Kotani, E., Yamakawa, M., Iwamoto, S., Tashiro, M., Mori, H., Sumida, M., Matsubara, F., Taniai, K., Kadono-Okuda, K., Kato, Y., 1995. Cloning and expression of the gene of hemocytin, an insect humoral lectin which is homologous with the mammalian von Willebrand factor. Biochim. Biophys. Acta 1260, 245-258.

Krautz, R., Arefin, B., Theopold, U., 2014. Damage signals in the insect immune response. Front Plant Sci 5, 342.

Krzemien, J., Dubois, L., Makki, R., Meister, M., Vincent, A., Crozatier, M., 2007. Control of blood cell homeostasis in Drosophila larvae by the posterior signalling centre. Nature $446,325-328$.

Krzemien, J., Oyallon, J., Crozatier, M., Vincent, A., 2010. Hematopoietic progenitors and hemocyte lineages in the Drosophila lymph gland. Dev. Biol. 346, 310-319.

Kurata, S., 2014. Peptidoglycan recognition proteins in Drosophila immunity. Dev Comp Immunol 42.

Kurucz, E., Márkus, R., Zsámboki, J., Folkl-Medzihradszky, K., Darula, Z., Vilmos, P., Udvardy, A., Krausz, I., Lukacsovich, T., Gateff, E., Zettervall, C.-J., Hultmark, D., Andó, I., 2007a. Nimrod, a putative phagocytosis receptor with EGF repeats in Drosophila plasmatocytes. Curr. Biol. 17, 649-654. 
Kurucz, E., Váczi, B., Márkus, R., Laurinyecz, B., Vilmos, P., Zsámboki, J., Csorba, K., Gateff, E., Hultmark, D., Andó, I., 2007b. Definition of Drosophila hemocyte subsets by cell-type specific antigens. Acta. Biol. Hung. 58 Suppl, 95-111.

Kurucz, E., Zettervall, C.-J., Sinka, R., Vilmos, P., Pivarcsi, A., Ekengren, S., Hegedüs, Z., Ando, I., Hultmark, D., 2003. Hemese, a hemocyte-specific transmembrane protein, affects the cellular immune response in Drosophila. Proc. Natl. Acad. Sci. U.S.A. 100, $2622-2627$.

Kwon, T.H., Lee, S.Y., Lee, J.H., Choi, J.S., Kawabata, S., Iwanaga, S., Lee, B.L., 1997. Purification and characterization of prophenoloxidase from the hemolymph of coleopteran insect, Holotrichia diomphalia larvae. Mol. Cells 7, 90-97.

Lanot, R., Zachary, D., Holder, F., Meister, M., 2001. Postembryonic hematopoiesis in Drosophila. Dev. Biol. 230, 243-257.

Laughton, A.M., Boots, M., Siva-Jothy, M.T., 2011. The ontogeny of immunity in the honey bee, Apis mellifera L. following an immune challenge. J. Insect Physiol. 57, 1023-1032.

Lavine, M.D., Strand, M.R., 2002. Insect hemocytes and their role in immunity. Insect Biochem. Mol. Biol. 32, 1295-1309.

Leitão, A.B., Sucena, É., 2015. Drosophila sessile hemocyte clusters are true hematopoietic tissues that regulate larval blood cell differentiation. Elife 4.

Lesch, C., Goto, A., Lindgren, M., Bidla, G., Dushay, M.S., Theopold, U., 2007. A role for Hemolectin in coagulation and immunity in Drosophila melanogaster. Dev. Comp. Immunol. 31, 1255-1263.

Lindsay, S.A., Wasserman, S.A., 2014. Conventional and non-conventional Drosophila Toll signaling. Dev. Comp. Immunol. 42, 16-24.

Lourenço, A.P., Zufelato, M.S., Bitondi, M.M.G., Simões, Z.L.P., 2005. Molecular characterization of a cDNA encoding prophenoloxidase and its expression in Apis mellifera. Insect Biochem. Mol. Biol. 35, 541-552.

Loof, T.G., Schmidt, O., Herwald, H., Theopold, U., 2011. Coagulation systems of invertebrates and vertebrates and their roles in innate immunity: the same side of two coins? J Innate Immun 3, 34-40. 
Manfredini, F., Dallai, R., Ottaviani, E., 2008. Circulating hemocytes from larvae of the paper wasp Polistes dominulus (Hymenoptera, Vespidae). Tissue Cell 40, 103-112.

Márkus, R., Laurinyecz, B., Kurucz, E., Honti, V., Bajusz, I., Sipos, B., Somogyi, K., Kronhamn, J., Hultmark, D., Andó, I., 2009. Sessile hemocytes as a hematopoietic compartment in Drosophila melanogaster. Proc. Natl. Acad. Sci. U.S.A. 106, 48054809.

Márkus, R., Lerner, Z., Honti, V., Csordás, G., Zsámboki, J., Cinege, G., Párducz, Á., Lukacsovich, T., Kurucz, É., Andó, I., 2015. Multinucleated Giant Hemocytes Are Effector Cells in Cell-Mediated Immune Responses of Drosophila. J Innate Immun 7, $340-353$.

Marringa, W.J., Krueger, M.J., Burritt, N.L., Burritt, J.B., 2014. Honey Bee Hemocyte Profiling by Flow Cytometry. PLoS One 9.

Martin, S.J., Medina, L.M., 2004. Africanized honeybees have unique tolerance to Varroa mites. Trends in Parasitology 20, 112-114.

Martinek, N., Shahab, J., Saathoff, M., Ringuette, M., 2008. Haemocyte-derived SPARC is required for collagen-IV-dependent stability of basal laminae in Drosophila embryos. J. Cell. Sci. 121, 1671-1680.

Matheson, A., 1996. World bee health update 1996. Bee World 77, 45-51.

Menail, A.H., Piot, N., Meeus, I., Smagghe, G., Loucif-Ayad, W., 2016. Large pathogen screening reveals first report of Megaselia scalaris (Diptera: Phoridae) parasitizing Apis mellifera intermissa (Hymenoptera: Apidae). J. Invertebr. Pathol. 137, 33-37.

Moritz, R.F.A., de Miranda, J., Fries, I., Le Conte, Y., Neumann, P., Paxton, R.J., 2010. Research strategies to improve honeybee health in Europe. Apidologie 41, 227-242.

Nam, H.-J., Jang, I.-H., Asano, T., Lee, W.-J., 2008. Involvement of pro-phenoloxidase 3 in lamellocyte-mediated spontaneous melanization in Drosophila. Mol. Cells 26, 606610.

Nakahara, Y., Kanamori, Y., Kiuchi, M., Kamimura, M., 2010. Two hemocyte lineages exist in silkworm larval hematopoietic organ. PLoS ONE 5, e11816. 
Nappi, A.J., Vass, E., Malagoli, D., Carton, Y., 2004. The effects of parasite-derived immune-suppressive factors on the cellular innate immune and autoimmune responses of Drosophila melanogaster. J. Parasitol. 90, 1139-1149.

Nardi, J.B., Pilas, B., Ujhelyi, E., Garsha, K., Kanost, M.R., 2003. Hematopoietic organs of Manduca sexta and hemocyte lineages. Dev. Genes Evol. 213, 477-491.

Negri, P., Maggi, M., Ramirez, L., Szawarski, N., Feudis, L.D., Lamattina, L., Eguaras, M., 2016. Cellular immunity in Apis mellifera: studying hemocytes brings light about bees skills to confront threats. Apidologie 47, 379-388.

Negri, P., Maggi, M., Szawarski, N., Lamattina, L., Eguaras, M., 2014. Apis mellifera haemocytes in-vitro, What type of cells are they? Functional analysis before and after pupal metamorphosis. Journal of Apicultural Research 53, 576-589.

Nunes, F.M.F., Simões, Z.L.P., 2009. A non-invasive method for silencing gene transcription in honeybees maintained under natural conditions. Insect Biochem. Mol. Biol. 39, 157-160.

Richard, F.-J., Aubert, A., Grozinger, C.M., 2008. Modulation of social interactions by immune stimulation in honey bee, Apis mellifera, workers. BMC Biol. 6, 50.

Richardson, R.T., Ballinger, M.N., Qian, F., Christman, J.W., Johnson, R.M., 2018. Morphological and functional characterization of honey bee, Apis mellifera, hemocyte cell communities. Apidologie 1-14.

Rizki, M.T., Rizki, R.M., 1959. Functional significance of the crystal cells in the larva of Drosophila melanogaster. J Biophys Biochem Cytol 5, 235-240.

Rizki, R.M., Rizki, T.M., 1984. Selective destruction of a host blood cell type by a parasitoid wasp. Proc. Natl. Acad. Sci. U.S.A. 81, 6154-6158.

Rizki, T.M., Rizki, R.M., 1992. Lamellocyte differentiation in Drosophila larvae parasitized by Leptopilina. Dev. Comp. Immunol. 16, 103-110.

Rodriguez, A., Zhou, Z., Tang, M.L., Meller, S., Chen, J., Bellen, H., Kimbrell, D.A., 1996. Identification of immune system and response genes, and novel mutations causing melanotic tumor formation in Drosophila melanogaster. Genetics 143, 929-940.

Roehrborn, G., 1961. Drosophila tumors and the structure of larval lymph glands. Experientia 17, 507-509. 
Royet, J., Dziarski, R., 2007. Peptidoglycan recognition proteins: pleiotropic sensors and effectors of antimicrobial defences. Nat. Rev. Microbiol. 5, 264-277.

Rothenbuhler, W.C., 1964. Behavior genetics of nest cleaning in honey bees. IV. Responses of F1 and backcross generations to disease-killed brood. Am. Zool. 4, 111123.

Rus, F., Kurucz, E., Márkus, R., Sinenko, S.A., Laurinyecz, B., Pataki, C., Gausz, J., Hegedus, Z., Udvardy, A., Hultmark, D., Andó, I., 2006. Expression pattern of Filamin240 in Drosophila blood cells. Gene Expr. Patterns 6, 928-934.

Samakovlis, C., Kimbrell, D.A., Kylsten, P., Engström, A., Hultmark, D., 1990. The immune response in Drosophila: pattern of cecropin expression and biological activity. EMBO J. 9, 2969-2976.

Sammataro, D., Gerson, U., Needham, G., 2000. Parasitic Mites of Honey Bees: Life History, Implications, and Impact. Annual Review of Entomology 45, 519-548.

Schlüshimns, H., Crozier, R.H., 2009. Molecular and chemical immune defenses in ants (Hymenoptera: Formicidae). Myrmecological News 12, 237-249.

Schneider, D.S., Jin, Y., Morisato, D., Anderson, K.V., 1994. A processed form of the Spätzle protein defines dorsal-ventral polarity in the Drosophila embryo. Development $120,1243-1250$.

Schmid, M.R., Brockmann, A., Pirk, C.W.W., Stanley, D.W., Tautz, J., 2008. Adult honeybees (Apis mellifera L.) abandon hemocytic, but not phenoloxidase-based immunity. J. Insect Physiol. 54, 439-444.

Shim, J., Lee, S.-M., Lee, M.S., Yoon, J., Kweon, H.-S., Kim, Y.-J., 2010. Rab35 Mediates Transport of Cdc42 and Rac1 to the Plasma Membrane during Phagocytosis. Mol Cell Biol 30, 1421-1433.

Shrestha, R., Gateff, E., 1986. Ultrastructure and cytochemistry of the tumorous blood cells in the mutant Lethal(3)malignant blood neoplasm of Drosophila melanogaster. Journal of Invertebrate Pathology 48, 1-12.

Simon-Delso, N., San Martin, G., Bruneau, E., Minsart, L.-A., Mouret, C., Hautier, L., 2014. Honeybee colony disorder in crop areas: the role of pesticides and viruses. PLoS ONE 9, e103073. 
Somogyi, K., Sipos, B., Pénzes, Z., Andó, I., 2010. A conserved gene cluster as a putative functional unit in insect innate immunity. FEBS Lett. 584, 4375-4378.

Somogyi, K., Sipos, B., Pénzes, Z., Kurucz, E., Zsámboki, J., Hultmark, D., Andó, I., 2008. Evolution of genes and repeats in the Nimrod superfamily. Mol. Biol. Evol. 25, $2337-2347$.

Sorrentino, R.P., Carton, Y., Govind, S., 2002. Cellular immune response to parasite infection in the Drosophila lymph gland is developmentally regulated. Dev. Biol. 243, $65-80$.

Tang, H., 2009. Regulation and function of the melanization reaction in Drosophila. Fly (Austin) 3, 105-111.

Tao, Y., Schulz, R.A., 2007. Heart development in Drosophila. Semin. Cell Dev. Biol. 18, $3-15$.

Theopold, U., Krautz, R., Dushay, M.S., 2014. The Drosophila clotting system and its messages for mammals. Dev. Comp. Immunol. 42, 42-46.

Theopold, U., Schmidt, O., Söderhäll, K., Dushay, M.S., 2004. Coagulation in arthropods: defence, wound closure and healing. Trends Immunol. 25, 289-294.

Ulvila, J., Vanha-Aho, L.-M., Rämet, M., 2011. Drosophila phagocytosis - still many unknowns under the surface. APMIS 119, 651-662.

vanEngelsdorp, D., Evans, J.D., Saegerman, C., Mullin, C., Haubruge, E., Nguyen, B.K., Frazier, M., Frazier, J., Cox-Foster, D., Chen, Y., Underwood, R., Tarpy, D.R., Pettis, J.S., 2009. Colony Collapse Disorder: A Descriptive Study. PLoS ONE 4, e6481.

Van Steenkiste, D., 1988. De hemocyten van de honingbij (Apis mellifera L.) : typologie, bloedbeeld en cellulaire verdedigingsreacties. Ph.D.-thesis, University of Ghent.

Vilmos, P., Kurucz, E., 1998. Insect immunity: evolutionary roots of the mammalian innate immune system. Immunol. Lett. 62, 59-66.

Vilmos, P., Nagy, I., Kurucz, E., Hultmark, D., Gateff, E., Andó, I., 2004. A rapid rosetting method for separation of hemocyte sub-populations of Drosophila melanogaster. Dev. Comp. Immunol. 28, 555-563.

Wallberg, A., Han, F., Wellhagen, G., Dahle, B., Kawata, M., Haddad, N., Simões, Z.L.P., Allsopp, M.H., Kandemir, I., De la Rúa, P., Pirk, C.W., Webster, M.T., 2014. A 
worldwide survey of genome sequence variation provides insight into the evolutionary history of the honeybee Apis mellifera. Nat Genet 46, 1081-1088.

Wilson-Rich, N., Dres, S.T., Starks, P.T., 2008. The ontogeny of immunity: development of innate immune strength in the honey bee (Apis mellifera). J. Insect Physiol. 54, $1392-1399$.

Winston, M.L., 1987. The Biology of the Honey Bee. Harvard University Press, Cambridge, Mass.

Yang, D., Zha, G., Li, X., Gao, H., Yu, H., 2017. Immune responses in the haemolymph and antimicrobial peptide expression in the abdomen of Apis mellifera challenged with Spiroplasma melliferum CH-1. Microb. Pathog. 112, 279-287.

Zettervall, C.-J., Anderl, I., Williams, M.J., Palmer, R., Kurucz, E., Ando, I., Hultmark, D., 2004. A directed screen for genes involved in Drosophila blood cell activation. Proc. Natl. Acad. Sci. U.S.A. 101, 14192-14197.

Zsámboki, J., Csordás, G., Honti, V., Pintér, L., Bajusz, I., Galgóczy, L., Andó, I., Kurucz, É., 2013. Drosophila Nimrod proteins bind bacteria. cent.eur.j.biol. 8, 633-645.

Zufelato, M.S., Lourenço, A.P., Simões, Z.L.P., Jorge, J.A., Bitondi, M.M.G., 2004. Phenoloxidase activity in Apis mellifera honey bee pupae, and ecdysteroid-dependent expression of the prophenoloxidase mRNA. Insect Biochem. Mol. Biol. 34, 1257-1268. 


\section{Saját közlemények jegyzéke}

\section{A dolgozat alapját képező közlemények:}

Cinege, G., Zsámboki, J., Vidal-Quadras, M., Uv, A., Csordás, G., Honti, V., Gábor, E., Hegedűs, Z., Varga, G.I.B., Kovács, A.L., Juhász, G., Williams, M.J., Andó, I., Kurucz, É., 2017. Genes encoding cuticular proteins are components of the Nimrod gene cluster in Drosophila. Insect Biochem. Mol. Biol. 87, 45-54.

$$
\text { IF:3,756 }
$$

MTMT: 3249679

Gábor, E., Cinege, G., Csordás, G., Török, T., Folkl-Medzihradszky, K., Darula, Z., Andó, I., Kurucz, É., 2017. Hemolectin expression reveals functional heterogeneity in honey bee (Apis mellifera) hemocytes. Dev. Comp. Immunol. 76, 403-411.

IF:3,218

MTMT: 3249751

\section{Egyéb közlemények:}

Gábor, E., Török, T., Csordás, G., Zsámboki, J., Kurucz, É., Andó, I., 2013. A házi méh (Apis mellifera) immunitása. Tudomány a vidék mindennapjaiban: Magyar Tudomány Ünnepe ISBN:978-963-306-245-6, pp. 29-34. (Könyvrészlet/Digitális kiadvány magyar nyelven)

MTMT: 2519812 